\title{
25. LOWER CRETACEOUS DIATOMS FROM ODP LEG 113 SITE 693 (WEDDELL SEA). PART 1: VEGETATIVE CELLS ${ }^{1}$
}

\author{
Rainer Gersonde ${ }^{2}$ and David M. Harwood ${ }^{3}$
}

\begin{abstract}
Exceptionally well preserved, nearshore, shallow water diatom assemblages of late Aptian to early Albian age (115$110 \mathrm{Ma}$ ) are described for Ocean Drilling Program (ODP) Site 693, Dronning Maud Land, Weddell Sea, Antarctica. These assemblages are significant because they allow insights into phylogenetic relationships during the little-known early evolution of diatoms and the status of diatom evolution by the Early Cretaceous. This contribution focuses on the diatom vegetative cells. A total of 12 new genera, 22 new species, 4 new varieties, and 1 new forma are described, and 5 new combinations are proposed. The genus Gladius Forti and Schulz (1932), including the species G. antiquus, is redescribed and taxa belonging to its later homonym Gladius Schulz (1935) are transferred to the new genus Gladiopsis. Valve characteristics of many of the described Lower Cretaceous taxa are: (1) a radial poroid basal layer; (2) pseudoloculate wall; and (3) the presence of a well developed apical linking apparatus, consisting of one or more three-buttressed linking spines and corresponding sockets (proposed name: scrobisculi). Taxa of six genera, which lack such an apical linking apparatus or have only rudimentary linking spines, bear structures that are interpreted to represent processes. Five different types of processes are described (proposed names: punctate-haplo process, scissurate-haplo process, perforate process, sipho-shaped process, and rhyncho-shaped process), that probably represent early stages of the modern labiate process and the strutted process. Thus, one prominent characteristic of the observed late Early Cretaceous diatoms is their chain forming ability.
\end{abstract}

\section{INTRODUCTION}

Ocean Drilling Program (ODP) Site 693 was drilled during Leg 113 off Dronning Maud Land on a mid-slope bench on the Weddell Sea margin of East Antarctica at $70^{\circ} 49.9^{\prime} \mathrm{S}$, $14^{\circ} 34.4^{\prime} \mathrm{W}$ (Fig. 1). At a sub-bottom depth of $398-410 \mathrm{~m}$, Holes 693A and 693B recovered upper Lower Cretaceous sediments containing a unique siliceous microfossil assemblage of well preserved marine planktonic diatoms, chrysophycean cysts, silicoflagellates, and radiolarians (see also Harwood and Gersonde, this volume; McCartney et al., this volume; Lazarus and Ling, this volume). This sequence falls within Lithostratigraphic Unit VI of Site 693 (Shipboard Scientific Party, 1988; Site 693). It is unconformably overlain by lower Oligocene diatomaceous sediments and underlain by dark terrigenous claystones and mudstones with organic rich beds and intercalated dark grey and black cherts (Lithostratigraphic Unit VII). Diatoms were also found in some of the cherts, but the preservation of these assemblages is generally poor. The upper portion of Lithostratigraphic Unit VII is late Aptian-early Albian in age, based on palynomorphs, calcareous nannofossils, and foraminifers (Mohr, this volume, chapter 29; Mutterlose and Wise, this volume; Leckie, this volume). Based on this age assignment a late Aptian-early Albian (probably early Albian) age can be deduced for the Cretaceous diatomaceous sequence. The Aptian-Albian age assignment is supported by the finding that diatom assemblages recovered in Queensland, Australia (Dun et al., 1901; Harper, 1977), and northwest Germany (Forti and Schulz, 1932), which have affinities in species composition with those recovered at Site 693, were dated to be Aptian and Albian, respectively.

\footnotetext{
${ }^{1}$ Barker, P. F., Kennett, J. P., et al., 1990. Proc. ODP, Sci. Results, 113: College Station, TX (Ocean Drilling Program).

2 Alfred Wegener Institute for Polar and Marine Research, Columbusstraße, D-2850 Bremerhaven, West Germany.

3 Byrd Polar Research Center and Department of Geology and Mineralogy, The Ohio State University, Columbus, Ohio 43210, USA. Present address: Department of Geology, University of Nebraska-Lincoln, Lincoln, NE 68588-0340, USA.
}

In Hole 693A the Cretaceous diatomaceous sediments and the contact to the overlying Oligocene sequences is poorly recovered. In contrast, at Hole 693B the sediment sequence containing the Oligocene/Albian-Aptian hiatus is continuously recovered, but the hole was abandoned after penetration of only about $0.4 \mathrm{~m}$ into the diatomaceous Cretaceous sediments. In the core description of Hole 693B published by Shipboard Scientific Party (1988, p. 447) the Oligocene/Cretaceous contact is erroneously indicated at Sample 113-693B-19X-2, $80 \mathrm{~cm}$. The accurate depth of the contact is at Sample 113-693B-19X-4, $69 \mathrm{~cm}$.

Previously, most Cretaceous sediments bearing well-preserved diatoms were known from the Campanian and Maestrichtian (Upper Cretaceous), and from the Albian and Aptian (late Early Cretaceous). Continuously recovered Upper Cretaceous diatom assemblages have been described by Strel'nikova $(1964,1965$, $1974,1975)$ from drillholes and outcrops in Siberia. Other reports are from the Moreno Shale in California (Hanna, 1927, 1934; Long et al., 1946), the Pierre Shale in Wyoming, Colorado, and Kansas (Bergstresser and Krebs, 1983), the Alpha Ridge in the Arctic Ocean (Kitchell and Clark, 1982; Barron, 1985), DSDP Site 275 from the Campbell Plateau south of New Zealand (Hajós and Stradner, 1975), Seymour Island, off the Antarctic Peninsula (Harwood, 1988), and from the northern Ural mountains, USSR (Strel'nikova, 1968, 1974). Schulz (1935) described diatoms from sediment enclosed in the canals of Senonian (Upper Cretaceous) hexactinellid sponges recovered from glacial detritus at the Bay of Gdansk (Poland). One new species was reported by Müller (1912) from Turonian sediments in western Germany.

Our knowledge of diatoms from the Early Cretaceous time period is more limited. Previously only one deposit in Queensland (Australia) and one deposit in northwest Germany were reported in which diatom valves are preserved in an opaline state (Fig. 2, Table 1). The Australian deposit was reported by Dun et al. (1901) and Harper (1977), but the species composition of the preserved diatom assemblage was not published (Harper, unpubl. notes). Based on the unpublished notes of Harper, a rather close resemblance between the diatom assemblages from 


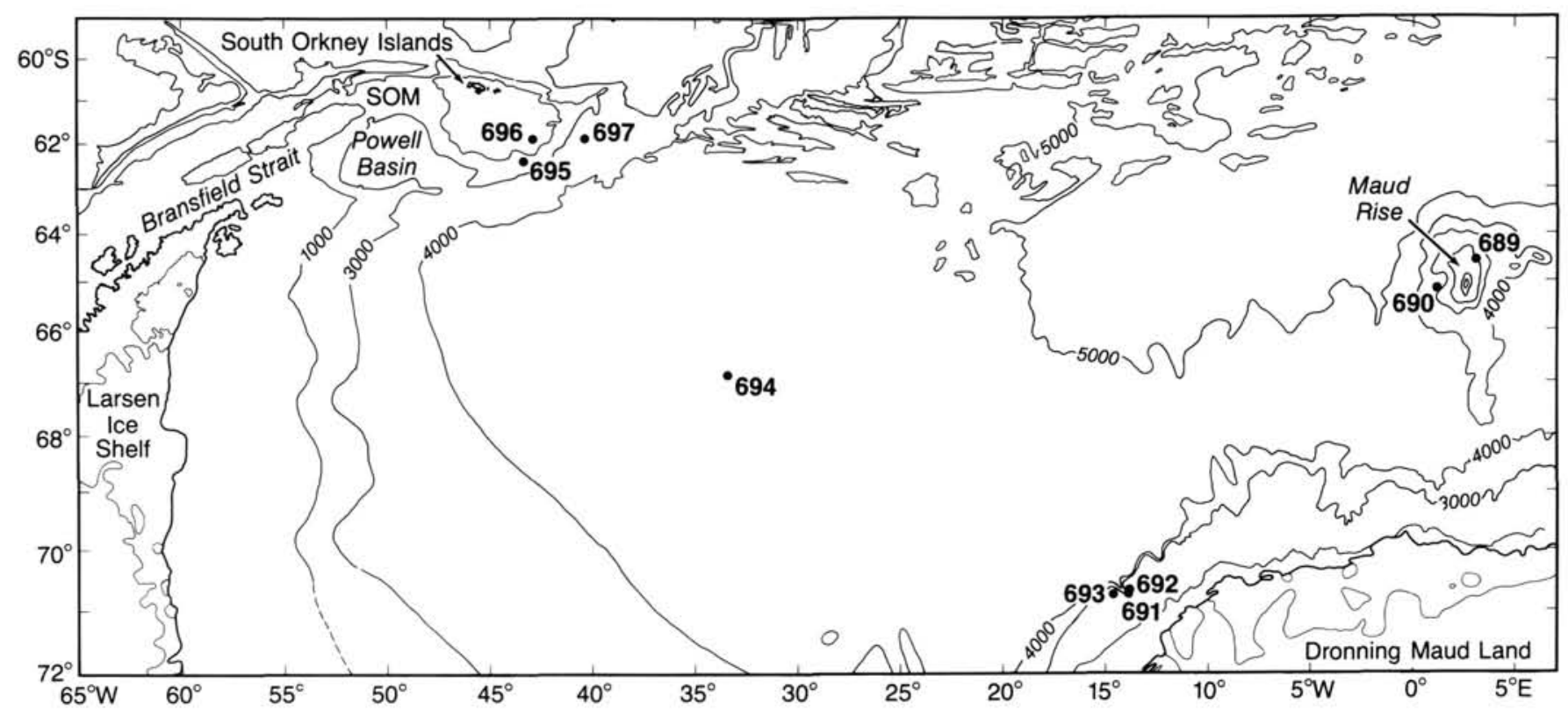

Figure 1. Location map showing the position of Site 693 and other Leg 113 sites. Bathymetric contours in meters from Tectonic Map (1985) and GEBCO sheet 5.16. (SOM = South Orkney microcontinent).

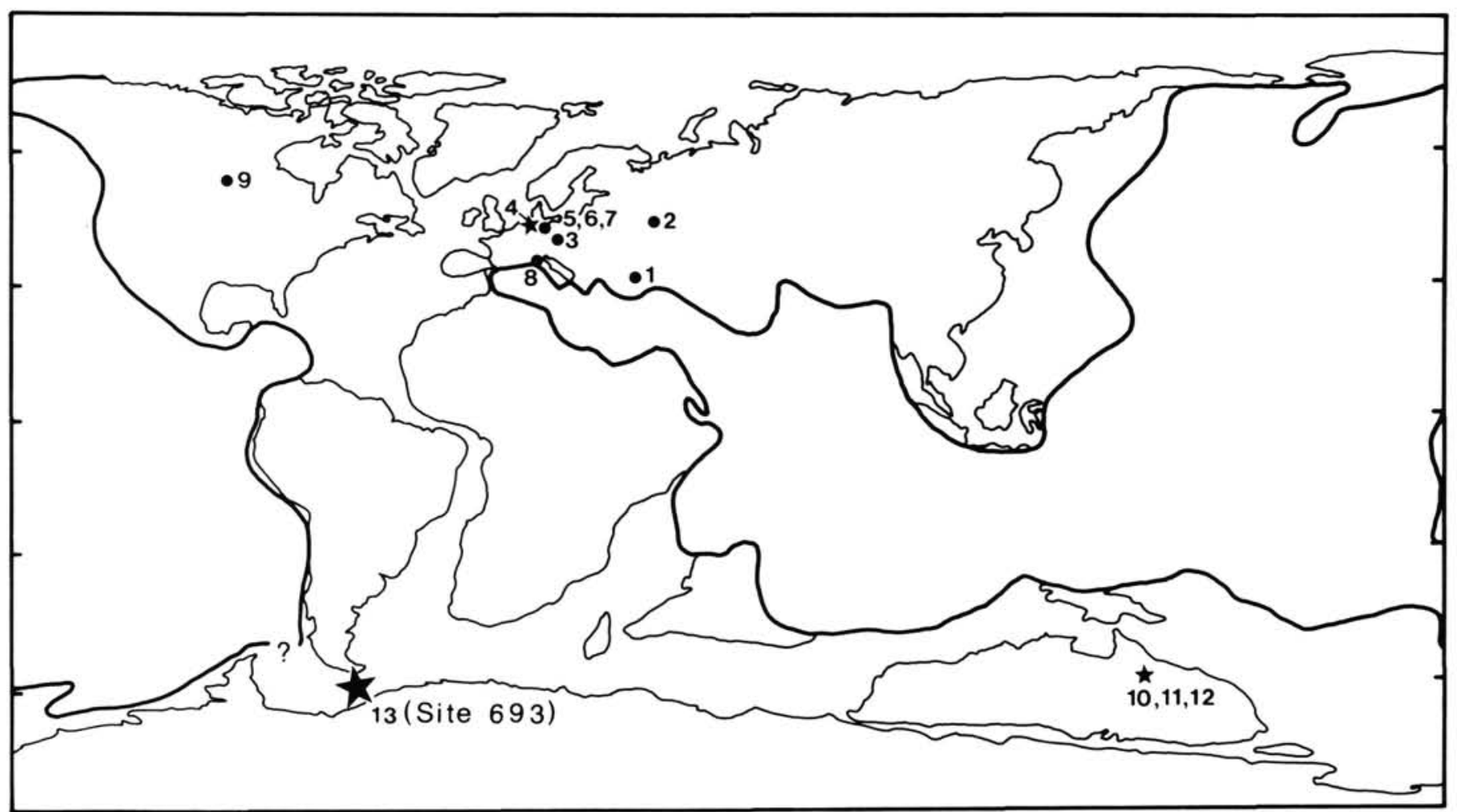

Figure 2. Location of Albian-Aptian diatom bearing deposits. Stars = deposits with opaline diatoms; dots = deposits with pyritized diatoms. Albian plate tectonic reconstruction from Barron (1987). 1. Strel'nikova and Martirosjan, 1981; 2. Jousé, 1949; 3. Geroch, 1978; 4. Forti and Schulz, 1932, and Rüst, 1885; 5. Kemper et al., 1975; 6. Georgi, 1976; 7. Benda, 1982; 8. Foucault et al., 1986; 9. Wall, 1975; 10. Dun et al., 1901; 11. Harper, 1977, and unpublished notes; 12. Haig and Barnbaum, 1978; 13. Gersonde and Harwood (this paper) and Harwood and Gersonde (this volume, ODP Site 693. (also compare Table 1). 
Table 1. Albian-Aptian diatom bearing deposits. For locations compare Figure 2.

\begin{tabular}{|c|c|c|c|c|c|c|}
\hline No. & Reference & Age & Locality & Preservation & Description & Remarks \\
\hline 1 & $\begin{array}{l}\text { Strel'nikova and Mar- } \\
\text { tirosjan, } 1981\end{array}$ & Albian & Stavropol, USSR & pyritized & $\begin{array}{l}14 \text { morphotypes related to Coscino- } \\
\text { discus (9), Aulacodiscus (1), } \\
\text { Lepidodiscus (1), Gladius (1), } \\
\text { Triceratium (1), Gen. indet (1) }\end{array}$ & \\
\hline 2 & Jousé, 1949 & Albian & $\begin{array}{l}\text { Penza region, } \\
\text { Volga area, } \\
\text { USSR }\end{array}$ & pyritized & & \\
\hline 3 & Geroch, 1978 & $\begin{array}{l}\text { Barremian to } \\
\text { Aptian }\end{array}$ & $\begin{array}{l}\text { Carpaths, Poland } \\
\text { Poland }\end{array}$ & pyritized & $\begin{array}{l}1 \text { species } \\
4 \text { morphotypes }\end{array}$ & \\
\hline 4 & Forti and Schluz, 1932 & Albian & $\begin{array}{l}\text { Northwest- } \\
\text { Germany }\end{array}$ & opaline valves & 9 genera, 11 species & $\begin{array}{l}\text { from phosphorite nodules, locality } \\
\text { unknown }\end{array}$ \\
\hline $4 \mathrm{a}$ & $\begin{array}{l}\text { Forti, } 1933 \\
\text { Rüst, } 1885\end{array}$ & ?Albian/Aptian & $\begin{array}{l}\text { Northwest- } \\
\text { Germany }\end{array}$ & opaline valves & $\begin{array}{l}\text { 1 species nov, nom. } \\
4 \text { morphotypes related to Tintinnus, } \\
\text { one to Coscinodiscus }\end{array}$ & $\begin{array}{l}\text { from phosphorite nodules ("coproliths") } \\
\text { locality: iron-ore deposits of Ilsede, } \\
\text { one species identified as Dictyolam- } \\
\text { pra stella }\end{array}$ \\
\hline 5 & Kemper et al., 1975 & late Aptian & $\begin{array}{l}\text { Northwest- } \\
\text { Germany }\end{array}$ & pyritized & & \\
\hline 6 & Georgi, 1976 & early Albian & $\begin{array}{l}\text { Northwest- } \\
\text { Germany }\end{array}$ & pyritized & 5 morphotypes & \\
\hline 7 & Benda, 1982 & late Aptian & $\begin{array}{l}\text { Northwest- } \\
\text { Germany }\end{array}$ & pyritized & 5 morphotypes & \\
\hline 8 & Foucault et al., 1986 & $\begin{array}{l}\text { Albian-early } \\
\text { Cenomanian }\end{array}$ & $\begin{array}{l}\text { Ligurian Alps } \\
\text { (Italy) }\end{array}$ & pyritized & $\begin{array}{l}2 \text { morphotypes related to Lithodes- } \\
\text { mium and ?Coscinodiscus }\end{array}$ & $\begin{array}{l}\text { species identified as Thalassiosiropsis } \\
\text { wittiana and Sheshukovia uralense }\end{array}$ \\
\hline 9 & Wall, 1975 & middle Albian & $\begin{array}{l}\text { Northeast Alberta, } \\
\text { Canada }\end{array}$ & pyritized & 5 morphotypes & \\
\hline 10 & Dun et al., 1901 & Aptian & $\begin{array}{l}\text { Queensland, } \\
\text { Australia }\end{array}$ & opaline valves & $\begin{array}{l}4 \text { morphotypes, one related to } \\
\text { Tintinnus }\end{array}$ & \\
\hline 11 & $\begin{array}{l}\text { Harper, } 1977 \text {, and } \\
\text { unpublished notes }\end{array}$ & Aptian & $\begin{array}{l}\text { Queensland, } \\
\text { Australia }\end{array}$ & opaline valves & $\begin{array}{l}10 \text { morphotypes, related to ?Hemi- } \\
\text { aulus (1), Pyrgodiscus (2), } \\
\text { Coscinodiscus (1), Stephanopyxis } \\
\text { (1), Gladius (1), Gen. indet (4) }\end{array}$ & $\begin{array}{l}\text { from carbonate concretions, morpho- } \\
\text { type descriptions unpublished, } \\
\text { species identified as Gladius anti- } \\
\text { quus, G. jouseana, Isthmia fortii, } \\
\text { Stephanopyxis mirabilis }\end{array}$ \\
\hline 12 & $\begin{array}{l}\text { Haig and Barnbaum, } \\
1978\end{array}$ & Aptian & $\begin{array}{l}\text { Queensland, } \\
\text { Australia }\end{array}$ & mostly pyritized & 8 morphotypes & $\begin{array}{l}\text { one species identified as Cladogramma } \\
\text { simplex }\end{array}$ \\
\hline 13 & $\begin{array}{l}\text { Gersonde and Harwood, } \\
\text { vegetative forms } \\
\text { (this paper) }\end{array}$ & $\begin{array}{l}\text { late Aptian- } \\
\text { early Albian }\end{array}$ & $\begin{array}{l}\text { ODP Site } 693 \text {, } \\
\text { Weddell Sea } \\
\text { margin }\end{array}$ & opaline valves & $\begin{array}{l}13 \text { genera with } 21 \text { species, } 4 \text { varieties } \\
\text { and } 1 \text { forma }\end{array}$ & species identified as Gladius antiquus \\
\hline & $\begin{array}{l}\text { Harwood and Gersonde, } \\
\text { resting spores (this } \\
\text { volume) }\end{array}$ & & & & 6 genera with 19 species & \\
\hline
\end{tabular}

Queensland, and those recovered at Site 693 can be deduced (see Discussion below). All other Lower Cretaceous diatom reports refer to poorly preserved pyritic internal clasts and provide little information. The Albian-Aptian diatom assemblages recovered at Site 693 represent the third known occurrence of opaline Lower Cretaceous diatoms. These assemblages are the best preserved of all published occurrences and provide new insight into an early state of diatom evolution.

The study by Forti and Schulz (1932) on Lower Cretaceous diatom assemblages from phosphorite nodules recovered from the "Gault" Formation (Albian) near Hannover (northwest Germany) was previously the most advanced study on Lower Cretaceous diatoms. Forti and Schulz (1932) described nine new species, one variety, and one forma from their material, including two new genera, Gladius and Radiodiscus. Because the latter name was a later homonym, this genus was given the new name Schulziella Hanna and Forti (Forti, 1933). Unfortunately, Forti and Schulz (1932) did not indicate a type locality. According to Benda (1982), the deposit can no longer be located nor any original raw or type material. Some of the diatoms described by Forti and Schulz (1932) also occur in the sediments studied in the present paper (see Discussion below) and the paper of Harwood and Gersonde (this volume).

About 50 yr before the paper of Forti and Schulz (1932) was published, Rüst (1885, pl. 44) illustrated in a paper on Jurassic radiolarians, among other siliceous microfossils (radiolarians, sponge spicules, ?silicoflagellates), six well preserved diatoms that were described as included in "coproliths" recovered from an iron-ore deposit also located in northwest Germany (Ilsede, near Peine). Those diatoms have affinities to taxa described in the present paper and the paper by Harwood and Gersonde (this volume). Rüst attributed only two of his forms to diatoms and labelled them as Coscinodiscus sp. and Dictyolampra stella Ehrenberg (pl. 44, figs. 6, 15). Of the Coscinodiscus only a fragment, unfortunately not including the central part of the valve face, is illustrated. It may be close to Praethalassiosiropsis. The diatom labelled as $D$. stella is close to resting spores described as Hyalotrochus and Calyptosporum by Harwood and Gersonde (this volume). Four of the diatoms were erroneously attributed to tintinnids (pl. 44, figs. 1-5). These diatoms can be related to Rhynchopyxis and probably to Gladius. Rüst (1885) assigned to the "coproliths" that bear the well preserved siliceous microfossil assemblages, a Jurassic (late Lias to early Dogger) age, based on the occurrence of two ammonites. However, according to E. Kemper (pers. comm., 1989) reworking of older fossils into younger strata is common in the Mesozoic sequences in the area of Rüst's locality and the age of the "coproliths," which presumably represent phosphorite nodules, is very probably Albian (Gault). It might even be speculated that the diatom bearing phosphorite nodules studied by Forti and Schulz (1932) originate in the same locality studied by Rüst (1885). For the discussion of other Cretaceous and pre-Cretaceous diatom reports and their significance we refer the reader to the paper by Harwood and Gersonde (this volume).

The present paper is focused on cells assumed to represent vegetative states. We will (1) document Lower Cretaceous diatoms recovered at Site 693 by descriptions, light microscope (LM), and scanning electron microscope (SEM) illustrations; (2) revise existing taxonomic work and designate neotypes if needed; (3) erect new taxa where needed; (4) divide the described taxa into groups and subgroups for discussion of relationships and features common to the investigated Lower Cretaceous diatoms. 
This will provide a basis for discussing generic and phylogenetic interrelationship of the recovered species and for discussing the status of diatom evolution by the Early Cretaceous. For more detailed discussion of the latter topics we prepare another paper that will be published elsewhere. Further papers documenting the variability of the diatom species, including biometric measurements, composition of diatom assemblages, and descriptions of other new but more rarely occurring taxa, which up to now are not very well documented by LM and SEM investigations, are in preparation. A companion paper (Harwood and Gersonde, this volume) describes the Lower Cretaceous diatom resting spores and chrysophycean cysts from the same sediments.

\section{METHODS AND MATERIALS}

Samples were taken aboard JOIDES Resolution during Leg 113 from core sections recovered from Holes 693A and 693B. The raw material was processed according to the procedures outlined by Abelmann et al. (in prep.) using gasoline for disaggregation of the sediment. To concentrate larger diatom species for morphological studies in LM and SEM, part of the material was sieved at $43 \mu \mathrm{m}, 63 \mu \mathrm{m}$, and $100 \mu \mathrm{m}$. The cleaned samples were prepared and mounted for LM-investigations (using the resin Mountex, $\mathrm{nd}=1.67$ ) and SEM-investigations according to Abelmann et al. (in prep.). LM investigations were made at Alfred Wegener Institute (AWI) and Byrd Polar Research Center with Leitz Orthoplan microscopes using apochromatic optics. Micrographs were made with an automatic Leitz Orthomat camera, many of them were produced using Nomarski illumination. The SEM investigations were carried out at the AWI with a Philips SEM 515. Because of the cylindrical outline of most of the species, which makes the interpretation of the LM-observations very difficult, the SEM studies were most important for delineation of the structure and ultrastructure of the diatom valves. The documentation of the investigated diatom species is based on about 500 SEM-micrographs, of which, however, only a minor portion can be shown in this paper. Measurements of diatom valve structures and terminology for the siliceous components follows the suggestions given by Ross and Sims (1972), Anonymous (1975), and Ross et al. (1979).

Samples bearing well preserved diatom assemblages investigated for this study are Samples 113-693A-44R-1, 14-18 cm, Section 113-693A-44R, CC, Samples 113-693B-19X-4, 77-78 cm and -19X-4, 103-104 cm, and Section 113-693B-19X-4, CC. Their stratigraphic position is given in Figure 3.

All types were marked on LM-slides with a diamond marker and deposited in the Friedrich-Hustedt Diatom Collection at the Alfred Wegener Institute, Bremerhaven.

\section{GENERAL}

The present study on vegetative diatoms and the companion paper (Harwood and Gersonde, this volume) are the first to investigate the morphological structures of Lower Cretaceous diatoms by combined light and scanning electron microscopy. All encountered diatoms can be attributed to the diatom order Centrales. Most of the taxa have a circular valve plane. Only two species, Bilingua rossii and Kerkis bispinosa, are characterized by bipolar valves.

Morphological features common to many of the recovered Lower Cretaceous diatoms are:

- cylindrical outline of the valve and elongated pervalvar axis,

- basal siliceous layer with radially oriented punctate striae,

- pseudoloculate valve structure,

- well-developed marginal ridge, and

- mechanisms for chain formation, that may be a well-developed apical linking apparatus or structures interpreted to represent processes.

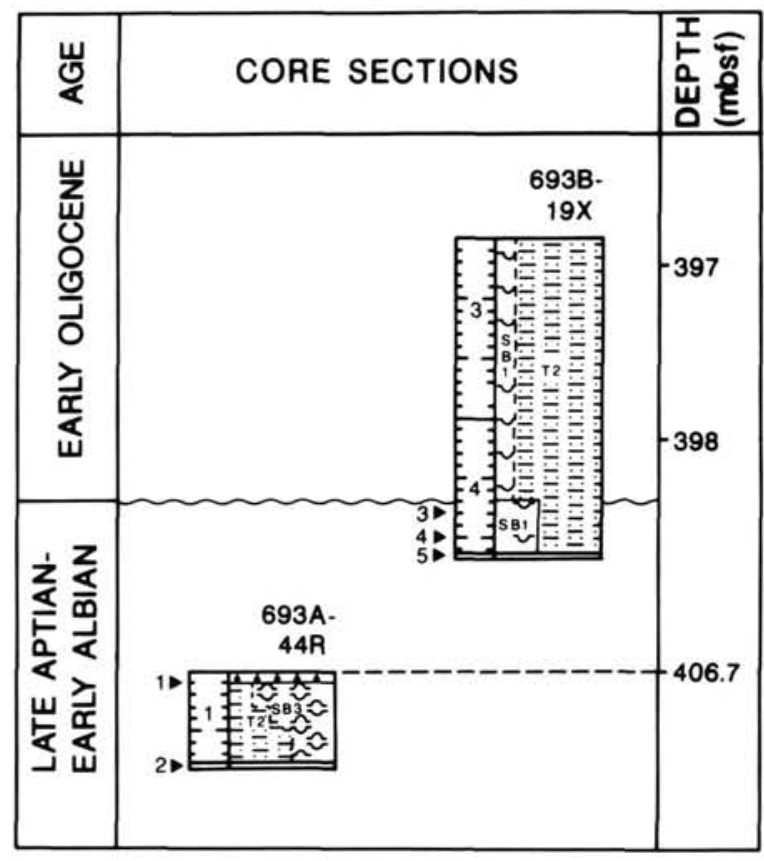

Figure 3. Location of diatom samples in Holes 693A and 693B used for this study. 1. Sample 113-693A-44R-1, 14-18 cm; 2. Section 113-693A44R, CC; 3. Sample 113-693B-19X-4, 77-78 cm; 4. Sample 113-693B$19 X-4,103-104 \mathrm{~cm}$; 5. Section 113-693B-19X, CC. Key to lithologic symbols. $\mathrm{T} 1=$ clay $/$ claystone; $\mathrm{T} 2=$ clayey $\mathrm{mud}$ and $\mathrm{mud} / \mathrm{mudstone} ;$ $\mathrm{SB} 1$ = diatom ooze; SB3 = diatom-radiolarian or siliceous ooze.

The apical linking apparatus consists of one or more strongly silicified linking spines (spinae ligantes) and sockets. The sockets are triangular or slit-like openings that are fused with the marginal ridge (Pl. 3, Figs. 4, 5, 8, 9; Pl. 5, Figs. 1-8; Pl. 8, Figs. 1, 2, 4-7; Pl. 9, Figs. 1, 2, 4, 5; Pl. 13, Figs. 2, 3, 5, 6, 8), or are fused with the basal part of a linking spine (only species bearing a solitary linking spine) ( $\mathrm{Pl}$. 6, Fig. 6), or are solitary on the valve face (PI. 12, Figs. 1-5, 7) some like a tulip flower (Pl. 6, Figs. 3-5, 7; Pl. 19, Figs. 11, 12). We propose to name a socket "scrobisculus."

The spines are three-buttressed, smooth or with serrate ornamentation. They may be located in the center of the valve face, subcentral or at the valve face margin. At their base the spines merge into three costae (Pl. 3, Fig. 9; Pl. 4, Fig. 18; Pl. 15, Figs. 3 , 8; Pl. 19, Figs. 11-13), or pseudolocular walls (Pl. 6, Figs. 17; Pl. 12, Figs. 1-7), or into one costa and the marginal ridge (Pl. 3, Figs. 4, 5, 8; Pl. 5, Figs. 3, 5-8; Pl. 8, Figs. 1-7; Pl. 13, Figs. $2,5,8$ ), or into one costa and marginal pseudoloculate thickenings (Pl. 9, Figs. 1-4). In one species (Gladius rhizophorus) the base of the three-buttressed spines merge into multifurcated costae spread on the valve face resembling roots (Pl. 7, Figs. 12, 14; Pl. 9, Fig. 5).

Some species have distinct slit-like or circular perforations, or more complex structures that are interpreted to represent processes. Species bearing one or more such processes do not have an apical linking apparatus, or the apparatus is reduced to small spines or costae and scrobisculi are not present. Five different types of processes, all located on the valve face, are distinguished.

\section{Punctate-haplo process}

Species of the genus Microorbis have a distinct, more thickly silicified central area that is perforated by scattered pores (PI. 2, Figs. 7, 8; Pl. 14, Fig. 3; Pl. 18, Figs. 1, 2; Pl. 19, Figs. 5, 6). The number of pores per individual central area is variable and 
ranges from 1 to 35 . We interpret these pores to represent processes and propose the name "punctate-haplo process" for them.

\section{Scissurate-haplo process}

The species Trochus elegantulus has one to three slit-like structures clustered in one section of the valve face about midway between the center of the valve face and its margin (Pl. 14, Figs. 1, $2,4,7 ; \mathrm{Pl} .15$, Figs. 1, 2, 11). The slits are arranged in line with the radial punctate striae and each slit is surrounded by a rim of silica on the outside of the valve. We propose the name "scissurate-haplo process" for this structure.

Bilingua rossii also bears a ring of radial oriented slit-like structures on the elevated central area (Pl. 17, Fig. 9; Pl. 18, Figs. 5, 6) that are interpreted to represent scissurate-haplo processes. Previously these structures could not be studied in SEM, because of the rare occurrences of $B$. rossii in the investigated material.

Considering the form and the position of the scissurate-haplo process we speculate that it represents an ancestral stage of the labiate process.

\section{Perforate process}

Praethalassiosiropsis hasleae has a central process consisting of a heavily silicified structure that is perforated by one larger central tube and numerous surrounding pores (Pl. 1, Figs. 2-3, 5-8; Pl. 2, Figs. 1, 2). The heavily silicified structure is a modified part of the internal layer of the valve (basal siliceous layer). The pores that surround the outer surface of this structure (Pl. 1, Fig. 7) are scattered or partly radially oriented, and are of the same size as other pores on the internal layer of the valve (Pl. 1, Figs. 3, 6, 8,9). The large tube extends inside the valve interior by a protrusion of the internal layer (Pl. 1, Figs. 3, 6, 8). Its marginal wall is perforated by radially arranged pores and its inner end is terminated by three or more radially arranged pores that are surrounded by a solid silicified ring (PI. 1, Figs. 3, 5, 6, 8 ). Rarely the termination is by slit-like structures instead of circular pores. The pores situated on the marginal wall of the internal tube are of the same size as the basal siliceous layer pores, except the pores adjacent to the solid ring and inside the solid ring, which are slightly larger in size. Because of the high number of pores of this process we propose the name "perforate process" for it.

\section{Sipho-shaped process}

Species of the genus Gladiopsis have a central apical process that, compared to the perforate process, consists of a heavily silicified structure, perforated by one larger central canal and surrounding numerous pores in radial arrangement (Pl. 11, Figs. 1, $4,6,7)$. The heavily silicified structure is the basal layer. The central tube protrudes on the inside (Pl. 10, Figs. 11, 13) and is flush with the outside of the valve. The internal structure of this process differs from that of the perforate process. The inside projection has a midway constriction and is not occluded at its inner end. Its wall is solid and only perforated by a ring of pores where it joins the basal layer. We propose the name "siphoshaped process" for this type.

Sipho-shaped processes also occur in Upper Cretaceous diatoms belonging to the genus Gladius Schulz (1935), herein transferred to Gladiopsis Gersonde and Harwood gen. nov.

\section{Rhyncho-shaped process}

The process of Rhynchopyxis siphonoides differs from the sipho-shaped process by its outer structure (Pl. 2, Figs. 3-6; Pl. 3, Figs. 1-3). It has a tube-like extension to the outside. The wall of the tube is solid and may thicken in some sections and at the distal end of the tube. On the outside of the valve the basal layer surrounding the base of the tube is solid and not perforated. The internal structure of the process (PI. 3, Fig. 3) is identical to that of the sipho-shaped process. We propose the name "rhyncho-shaped process" for it.
Possibly a rhyncho-shaped process is also present in taxa identified as Gladius speciosus f. poratus Strel'nikova (1974) and $G$. speciosus f. aculeolatus Strel'nikova (1974), originally described by Strel'nikova (1966) as Pyxilla speciosa f. porata and $P$. speciosa f. aculeolata from Campanian diatomaceous claystones from the eastern slope of the sub-polar Ural mountains. Both taxa bear an apical process that is tube-like and extended to the outside, ca. 5-10 $\mu \mathrm{m}$ long in $G$. speciosus f. porata and somewhat shorter in G. speciosus f. aculeolatus. However, based on the photographs and description of the apical structure of these taxa given by Strel'nikova $(1966$, p. 35, pl. 4, figs. 3-6, 11-12) and the only published SEM-illustration (Glezer et al., 1988 , pl. 35 , fig. 8 , process of $G$. speciosus f. aculeolatus) we cannot definitely decide if they represent true rhyncho-shaped processes.

By their internal structure the perforate, the sipho-shaped, and the rhyncho-shaped processes are possible older homologs to the multistrutted process of Hasle and Syvertsen (1985) (= annular process of Nikolaev and Strel'nikova, 1987) and the strutted process (fultoportula).

While there are no discernible structures that can be related to a linking apparatus in species of the genera Praethalassiosiropsis and Rhynchopyxis, species of Bilingua, Gladiopsis, Microorbis, and Trochus bear small spines or costae which are interpreted to represent a rudimentary linking apparatus. These structures were probably without function because scrobisculi or other means for spine attachment were not detected. The presence of a rudimentary apical linking apparatus represented by a corona of short spines or spinulae situated at the margin of the valve face is characteristic for the Lower Cretaceous species of Gladiopsis (Pl. 11, Figs. 1, 3, 6-8). In Late Cretaceous Gladiopsis species the reduction of the linking apparatus is apparently completed because rudimentary linking apparatus structures cannot be observed. The valve face of Trochus elegantulus is ornamented with radial oriented costae, which fuse in the center of the valve face. This may represent a rudimentary apical linking apparatus with one central spine (Pl. 14, Figs. 1, 4, 7 ; Pl. 15, Figs. 1, 2, 11). The central elevation of Bilingua rossii is ornamented by a costate structure, which may represent a rudimentary apical linking apparatus with two centrally situated spines (Pl. 17, Fig. 9; Pl. 18, Figs. 5, 6). Radial costae restricted to the outer $1 / 3$ to $1 / 2$ of the valve face and bifurcated near the valve face margin that bear one linking spine at each point of bifurcation occur in valves assigned to the ?heterovalvate species Microorbis convexus. (Pl. 18, Figs. 3, 4, 8). Also in this species, attachment points for linking spines, such as scrobisculi, were not detected.

\section{DESCRIPTION OF LOWER CRETACEOUS DIATOM TAXA}

AMBLYPYRGUS Gersonde and Harwood, gen. nov.

Description. Valve cylindrical, pervalvar axis straight to slightly curved. Valve face and mantle pseudoloculate. Valve face convex. Arrangement of linking structures on valve face bilateral, linking spines and scrobisculi forming a rectangle.

Type species. Amblypyrgus campanellus Gersonde and Harwood, sp. nov.

Derivation of name. amblys (Gk.)-blunt; pyrgos (Gk.)-tower

Amblypyrgus campanellus Gersonde and Harwood, sp. nov. (Pl. 12, Figs. 1-9; Pl. 15, Figs. 4, 5, 9, 10, 12, 13; Pl. 19, Figs. 3, 4)

Description. Valve cylindrical. Pervalvar axis moderately elongated, straight to slightly curved, individual valve $15-50 \mu \mathrm{m}$ in height (excluding linking spines). Presence of apical linking apparatus indicates chain formation. Terminal valves of chains without linking apparatus (PI. 12, Figs. 8, 9; Pl. 15, Figs. 4, 5). Girdle not observed. Valve face circular, convex (12-30 $\mu \mathrm{m}$ in diameter). Valve face and mantle pseudoloculate. Basal siliceous layer with radial punctate striae (18-24 in $10 \mu \mathrm{m})$ in quin- 
cunx pattern. Pores are frequently filled (Pl. 12, Fig. 6) where pseudolocular walls join with the basal layer in a hexagonal pattern. Basal siliceous layer slightly constricted between apical part of valve mantle and mantle edge (Pl. 12, Fig. 6; Pl. 15, Figs. 4, 10; Pl. 19, Fig. 4). Constriction compensated by more strongly developed pseudolocular walls, leading to a straight external mantle outline. Pseudoloculi hexagonal with sub-circular openings, arrangement on valve face in regular tangential straight to curved rows, on valve mantle in horizontal and diagonal rows that spiral around the valve, 6-8 pseudoloculi in $10 \mu \mathrm{m}$. Mantle edge with narrow "Ringleiste" and serrate ornamentation. Serration consisting of lines of granulae (Pl. 12, Fig. 7). Linking apparatus on valve face consists of two three-buttressed spines often connected together at their base, and two opposite scrobisculi of triangular shape (PI. 12, Figs. 1-7). Length of linking spines 3-12 $\mu \mathrm{m}$. Scrobisculi and spines sometimes connected by less developed costae forming a rectangular structure. Position of linking apparatus variable, in center of valve face or eccentrically situated. In individuals with curved pervalvar axis the linking apparatus is eccentric in the direction of curvature and the spines are situated close to margin of valve face (Pl. 12, Fig. 3).

Holotype (specimen with linking apparatus). Friedrich-Hustedt Collection No. Zu 3/90 (Pl. 19, Figs. 3, 4).

Paratype (specimen without linking apparatus). Friedrich-Hustedt Collection No. Zu 3/98 (Pl. 15, Figs. 4, 5).

Type locality. Weddell Sea margin, Dronning Maud Land coast, Antarctica, ODP Site 693.

Type level. Marine late Aptian-early Albian, ODP Sample 113-693B$19 \mathrm{X}-4,77-78 \mathrm{~cm}$.

Other occurrences. Unconfirmed reports from the Albian in northwest Germany (Forti and Schulz, 1932) and from the Aptian/Albian in Queensland, Australia (Harper, unpublished).

Discussion. Amblypyrgus campanellus is the only species recovered from the present Albian/Aptian sample set interpreted as having intercalary and terminal valves that are differentiated by the presence and absence, respectively, of an apical linking apparatus. This could not be documented by the presence of an intact chain but was deduced by the similarity in general valve structure between the forms with and without a linking apparatus. Another indication for this interpretation is, that except for $A$. campanellus, all other species lacking a distinct linking apparatus have a central process that can be used for colony formation. A. campanellus has affinities to Ancylopyrgus reticulatus in the structure of the valve face. It differs by the lack of a marginal ridge and possession of a double-spined linking apparatus. The curved forms of $A$. campanellus are the most similar to Ancylopyrgus reticulatus var. elongatus in structure and position of the linking spines and the scrobisculi.

Remarks. We have called this species Amblypyrgus campanellus because we think it possible that it is the taxon called Stephanopyxis turris var. campanella Forti and Schulz (1932, p. 246, text-fig. 5), but, as no type material is available, we are unable to treat it as a synonym.

ANCYLOPYRGUS Gersonde and Harwood, gen. nov.

Description. Valve cylindrical, pervalvar axis elongated and curved. Valve face and mantle pseudoloculate. Valve face with single straight linking spine, eccentric, pointed in direction of curvature of the pervalvar axis.

Type species. Ancylopyrgus reticulatus Gersonde and Harwood, sp. nov.

Derivation of name. ankylos (Gk.)—curved; pyrgos (Gk.)-tower

Ancylopyrgus reticulatus Gersonde and Harwood, sp. nov.

(Pl. 4, Figs. 1-4; Pl. 6, Figs. 1, 3-7; Pl. 17, Figs. 5, 6)

Description. Valve cylindrical, short (height/breadth ratio of valves: 0.8-1.6). Pervalvar axis moderately elongated and curved, individual valves $15-30 \mu \mathrm{m}$ in height (excluding linking spine). Presence of apical linking apparatus indicates chain formation. Girdle not observed. Valve plane circular (10-25 $\mu \mathrm{m}$ in diameter), eccentrically domed in direction of curvature of pervalvar axis with one straight linking spine (Pl. 6, Figs. 4,6$)$. Basal siliceous layer with radial punctate striae (20-24 in 10 $\mu \mathrm{m}$ ) in quincunx pattern. Pores frequently filled where pseudolocular walls join with the basal layer in a hexagonal pattern (Pl. 6, Fig. 1). Pseudoloculi arrangement in curved rows on valve face, and in horizontal, curved, and diagonal rows on valve mantle (5-7 in $10 \mu \mathrm{m}$ ). Pseudoloculi hexagonal with circular openings when well developed. Pseudolocular walls on valve face and apical part of valve mantle less devel- oped. Mantle edge narrow and hyaline (Pl. 6, Figs. 1, 4-6). Valve face and mantle separated by well developed marginal ridge, projecting at an approximate right angle from the valve face surface and strutted by pseudoloculate structure on valve mantle side (PI. 6, Figs. 3-7). Linking spine solid, three-buttressed and elongated, length of spines 10-20 $\mu \mathrm{m}$. Scrobisculus small, consisting of triangular fan-like structure ("tulip flower" structure, height $\sim 5 \mu \mathrm{m}$ ) attached to the valve face with its narrow base close to linking spine base (Pl. 6, Figs. 3-5, 7) or coalescing with the linking spine (Pl. 6, Fig. 6).

Holotype. Friedrich-Hustedt Collection No. Zu 3/84 (Pl. 17, Figs. $5,6)$.

Type locality. Weddell Sea margin, Dronning Maud Land coast, Antarctica, ODP Site 693.

Type level. Marine late Aptian-early Albian, ODP Sample 113-693B$19 \mathrm{X}-4,77-78 \mathrm{~cm}$.

Other occurrences. An unconfirmed report from the Aptian/Albian in Queensland, Australia by Harper (unpublished).

Derivation of name. reticulatus (Lat.)-reticular

Ancylopyrgus reticulatus var. elongatus Gersonde and Harwood, var. nov.

(Pl. 4, Figs. 19, 20, 23, 24; Pl. 6, Fig. 2)

Diagnosis. Differs from var. reticulatus by its more elongated valve outline (height/breadth ratio: $2.5-4.5$ ). Height of valve $30-40 \mu \mathrm{m}$; diameter of valve face $7-15 \mu \mathrm{m} ; 5-8$ pseudoloculi in $10 \mu \mathrm{m}$. The marginal ridge might be less developed than in the species or not differentiated. The scrobisculus is situated very close to the base of the linking spine or coalesces with the spine. Length of linking spine 10-15 $\mu \mathrm{m}$.

Holotype. Friedrich-Hustedt Collection No. Zu 3/85 (Pl. 4, Figs. 19, 20).

Type locality. Weddell Sea margin, Dronning Maud Land coast, Antarctica, ODP Site 693.

Type level. Marine late Aptian-early Albian, ODP Sample 113-693B$19 \mathrm{X}-4,77-78 \mathrm{~cm}$.

Other occurrences. An unconfirmed report from the Aptian/Albian in Queensland, Australia by Harper (unpublished).

Discussion. The two varieties of $A$. reticulatus are possibly close to forms described by Forti and Schulz (1932, p. 242, table 3, figs. 7, 7a, 8) as Isthmia fortii. The similarity is in the general valve structure (as far as can be deduced from the description), and the presence of one elongated linking spine in eccentric position on the valve face. As in A. reticulatus, Forti and Schulz (1932) differentiate between an elongated and a shorter morphotype. The species described by Forti and Schulz differs from $A$. reticulatus by its straight pervalvar axis.

\section{ARCHEPYRGUS Gersonde and Harwood, gen. nov.}

Description. Valve cylindrical, pervalvar axis moderately elongated, straight. Valve face with radial areolae, central area, and radial costae terminating at valve face margin with a linking spine. Valve mantle regularly ornamented with fine structured areolae. Distinct "Ringleiste".

Type species. Archepyrgus melosiroides Gersonde and Harwood, sp. nov.

Derivation of name. archaios (Gk.)—old; pyrgos (Gk.)-tower

Archepyrgus melosiroides Gersonde and Harwood, sp. nov. (Pl. 10, Figs. 2-6, 14, 15; Pl. 13, Figs. 1-8)

Description. Valve cylindrical, forming chains connected by an apical linking apparatus. Pervalvar axis straight and moderately elongated, individual valves $10-25 \mu \mathrm{m}$ in height (excluding linking spines). Valve face circular, slightly convex, 5-20 $\mu \mathrm{m}$ in diameter. Valve face hyaline, except near the valve face margin, which is ornamented with radially oriented rows of areolae. Valve face with 4-7 costae, radially oriented, each coalescing with the base of the proximal wing of one linking spine and extending toward the valve center. The number of costae and linking spines is positively correlated with the diameter of the valve face. Valve mantle straight, with rows of fine areolae in quincunx pattern running parallel to the pervalvar axis. Size of areolae variable, 12-28 in $10 \mu \mathrm{m}$. Outside of valve mantle straight, inside slightly curved due to gradual thickening of the mantle wall in the middle portion of the mantle $(\mathrm{Pl}$. 10, Fig. 3, 5, 15). Mantle edge characterized by hyaline "Ringleiste", $2-$ $3 \mu \mathrm{m}$ broad (Pl. 13, Fig. 4). Apical linking apparatus consisting of 4-7 marginal linking spines and corresponding scrobisculi. Spines are of 
equal length (4-6 $\mu \mathrm{m})$ and consist of three wings which taper toward the apex (three-buttressed spines), the outside part being a prolongation of the outside of the valve mantle (Pl. 13, Figs. 2, 3, 5, 8). Linking spines overlap the adjacent valve, interdigitating with the corresponding linking spines, leading to a close connection between the individual valves (Pl. 13, Fig. 1). Scrobisculi structured like V-shaped grooves with a central pervalvarly oriented slit (Pl. 13, Figs. 2, 3, 8). Girdle structure striate punctate with pores in quincunx pattern running parallel to the pervalvar axis (Pl. 13, Fig. 7).

Holotype. Friedrich-Hustedt Collection No. Zu 3/97 (Pl. 10, Figs. $14,15)$.

Type locality. Weddell Sea margin, Dronning Maud Land coast, Antarctica, ODP Site 693.

Type level. Marine late Aptian-early Albian, ODP Sample 113-693B$19 \mathrm{X}-4,103-104 \mathrm{~cm}$.

Discussion. The general outline of the valve, structure of the areolae, valve mantle and linking apparatus, and the presence of a distinct "Ringleiste" indicate close relationships to species of the genus Aulacoseira Thwaites. We found one frustule showing a state of vegetative cell division with a girdle band still covering the newly formed hypovalve (Pl. 13, Figs. 6, 7).

\section{BASILICOSTEPHANUS Gersonde and Harwood, gen. nov.}

Description. Valve cylindrical, pervalvar axis straight or slightly curved. Valve face with radial punctate striae and radial costae each terminating at valve margin with an elongated three-buttressed linking spine. Distinct central area. Structure of valve mantle variable: pseudoloculate or punctate basal siliceous layer.

Type species. Basilicostephanus ornatus Gersonde and Harwood, sp. nov.

Derivation of name. basilikos (Gk.)—royal; stephanos (Gk.)—crown

Basilicostephanus ornatus Gersonde and Harwood, sp. nov.

(Pl. 3, Fig. 4; Pl. 4, Figs. 5-12, 15-17; Pl. 5, Figs. 1-8)

Description. Valve cylindrical, size highly variable. Pervalvar axis short, straight to slightly curved. Valves $4-15 \mu \mathrm{m}$ in height (excluding linking spines). Frustules forming cylindrical chains connected by apical linking apparatus (Pl. 4, Figs. 7, 8; Pl. 5, Figs. 1-4). Girdle bands segmented and with punctate striae ( $\mathrm{Pl}$. 5, Figs. 1, 2). Valve face circular, slightly convex, (4-20 $\mu \mathrm{m}$ in diameter), with radial punctate striae (2428 pores in $10 \mu \mathrm{m}$ ), and 3-12 radially oriented costae. Central area distinct, hyaline or with scattered pores (Pl. 4, Figs. 9, 11; Pl. 5, Figs. 4, 7, $8)$. Valve face separated from valve margin by solid marginal ridge, projecting at about a right angle from valve face surface and strutted by pseudoloculate structure on the valve mantle side. Pseudoloculate structure of valve mantle variable, from well ordered hexagonal pseudoloculi arranged in horizontal and diagonal rows (7-10 pseudoloculi in $10 \mu \mathrm{m})$ (Pl. 5, Figs. 6, 7), to disordered thickenings (PI. 5, Figs. 3, 5). Pseudoloculi often less developed in apical part of valve mantle. Basal siliceous layer of valve mantle of vertical punctate striae slightly constricted near mantle edge ( $\mathrm{Pl}$. 4, Figs. 6, 15). Straight valve mantle outline, compensated by increasing depths of pseudoloculi walls (PI. 5, Fig. 2). Mantle margin broad with sulcus and "Ringleiste" with serrate ornamentation (PI. 5, Figs. 2, 3, 5). Sulcus loculate or divided with disordered thickenings. Serration consisting of lines of granulae. Length of costae on valve face variable, extending from valve margin to valve center or shorter. Costae strictly radially oriented or diverging in one direction near valve face center. Rarely costae bifurcate near valve face center. Costa wall thickens toward valve face margin, coalesces with marginal ridge and terminates with a three-buttressed linking spine. Scrobisculi slit-like, open on the outside, located on marginal ridge close to the base of a linking spine. Length of linking spines 8-15 $\mu \mathrm{m}$ leading to an "open" connection between valves in chain formation (Pl. 4, Fig. 7; Pl. 5, Figs. $1,3)$. 16).

Holotype. Friedrich-Hustedt Collection No. Zu 3/97 (PI. 4, Fig. 15,

Paratype. Friedrich-Hustedt Collection No. Zu 3/88 (Pl. 4, Fig. 17). Type locality. Weddell Sea margin, Dronning Maud Land coast, Antarctica, ODP Site 693.

Type level. Marine late Aptian-early Albian, ODP Sample 113-693B$19 \mathrm{X}-4,77-78 \mathrm{~cm}$.

Discussion. $B$. ornatus is closely related to $B$. mirabilis, which differs by lacking a pseudoloculate structure on the valve mantle and by a less developed sulcus.
Basilicostephanus mirabilis Gersonde and Harwood, sp. nov. (Pl. 2, Figs. 11, 12; Pl. 3, Figs. 5, 7, 8; Pl. 4, Figs. 13, 14, 21, 22; Pl. 19, Figs. 7, 8)

Description. Valve cylindrical. Pervalvar axis short to moderately long, straight to slightly curved, individual valves 5-20 $\mu \mathrm{m}$ in height (excluding linking spines). Forming cylindrical chains connected by apical linking apparatus. Girdle not observed. Valve face circular, slightly convex, (8-15 $\mu \mathrm{m}$ in diameter), with radial punctate striae (24-32 pores in $10 \mu \mathrm{m}$ ), and 3-6 radial costae. Central area hyaline or with scattered pores. Valve face separated from valve margin by marginal ridge, projecting at about a right angle from valve face surface. Valve mantle with punctate striae, striae running parallel to the pervalvar axis (24-32 pores in $10 \mu \mathrm{m}$ ), pores in general in quincunx pattern (Pl. 3, Figs. 5, 8). Mantle margin distinct, with weakly developed sulcus and broad "Ringleiste" with serrate ornamentation. Sulcus divided by punctum-like structures. Serration consisting of lines of granulae. Length of costae on valve face variable, extending from valve margin to valve center or shorter. Costae strictly radial or diverging in one direction near center of valve face. Costa wall thickens toward valve margin, coalescing with marginal ridge and terminating with three-buttressed linking spine. Scrobisculi slit-like, open to the outside and located on marginal ridge (Pl. 3 , Figs. 5, 8). Length of linking spines 5-20 $\mu \mathrm{m}$, leading to an "open" connection between valves in chain formation.

Holotype. Friedrich-Hustedt Collection No. Zu 3/86 (Pl. 19, Figs. $7,8)$.

Type locality. Weddell Sea margin, Dronning Maud Land coast, Antarctica, ODP Site 693.

Type level. Marine late Aptian-early Albian, ODP Sample 113-693B$19 \mathrm{X}-4,77-78 \mathrm{~cm}$.

Other occurrences. Unconfirmed reports from the Albian in northwest Germany (Forti and Schulz, 1932) and from the Aptian/Albian in Queensland, Australia by Harper (unpublished).

Discussion. $B$. mirabilis differs from $B$. ornatus by lacking a pseudoloculate structure on the valve mantle and having a less developed sulcus.

Remarks. We have called this species Basilicostephanus mirabilis because we think it possible that it belongs to a taxon called Stephanopyxis mirabilis Forti and Schulz, (1932, p. 246, text-fig. 6). Eleven illustrations of the species are given by Forti and Schulz in their text-figure 6 , showing a broad variety of forms, one of them consisting of a heterovalvate frustule (text-fig. 6, fig. 5) and two of them are labelled as "juvenile forms" (text-fig. 6, figs. 4, 5). This variety of forms may include vegetative cells and spores (e.g., text-fig. 6 , figs. 9, 11, see description and remarks for Calyptosporum exasperatum in Harwood and Gersonde, this volume) and probably represents more than one species. However, in their description Forti and Schulz (1932) focus on one form illustrated in their text-figure 6 , figures 7 and 8 , that has strong similarities to Basilicostephanus mirabilis. Unfortunately no type material of Forti and Schulz's taxon is available, so that we are unable to treat it as a synonym.

Glezer (1984, p. 291) transferred the variety of forms named Stephanopyxis mirabilis to Costopyxis mirabilis treating Stephanopyxis Ehrenberg $(1844$, p. 294$)$ as a synonym of Costopyxis Glezer (1984, p. 291). Our attention was drawn to this transfer because of its quotation in the diatom atlas of Glezer et al. (1988, p. 51, text-fig. 3). However, we ignore the reference Glezer (1984) because it is not included in the reference list of Glezer et al. (1988).

\section{BILINGUA Gersonde and Harwood, gen. nov.}

Description. Valve symmetry bipolar. Valve face and mantle with siliceous layer of punctate striae. Poles and center marked by elevations, central elevation ornamented with costa and central ring of radial oriented slit-like structures (scissurate-haplo processes). Valve face and valve mantle separated by marginal ridge.

Type species. Bilingua rossii Gersonde and Harwood, sp. nov.

Bilingua rossii Gersonde and Harwood, sp. nov.

(Pl. 17, Fig. 9; Pl. 18, Figs. 5-7, 9)

Description. Valve with bipolar symmetry, straight, 38-70 $\mu \mathrm{m}$ long, $18-20 \mu \mathrm{m}$ broad at center and $10-13 \mu \mathrm{m}$ at poles. Poles and center marked by elevations. Central portion circular and steeply elevated (PI. 18 , Fig. 7), poles broadly rounded. Valve face and valve mantle consisting of basal siliceous layer with radial punctate striae (28-35 pores in 
$10 \mu \mathrm{m})$. Valve mantle steep and slightly concave at the poles. Valve face separated from valve margin by steep marginal ridge that is well developed in the depression between the central and polar elevations (Pl. 18, Figs. 7, 9). Central elevation ornamented by one apical costa that bifurcates at both of its ends near the margin of the central elevation and coalesces with a short linking spine at each point of bifurcation (PI. 17, Fig. 9; Pl. 18, Fig. 5). Central elevation with central ring of 8-9 radial oriented slit-like structures (scissurate-haplo processes) (PI. 17, Fig. 9; Pl. 18, Fig. 5). $5,6)$.

Holotype. Friedrich-Hustedt Collection No. Zu 3/85 (Pl. 18, Figs.

Type locality. Weddell Sea margin, Dronning Maud Land coast, Antarctica, ODP Site 693.

Type level. Marine late Aptian-early Albian, ODP Sample 113-693B$19 \mathrm{X}-4,77-78 \mathrm{~cm}$.

Derivation of name. Dedicated to Robert Ross, Department of Botany, British Museum, London.

Discussion. By its bipolar valve symmetry and the presence of a ring of process-like structures on the central elevation this taxon has affinities to diatoms of the suborder Biddulphiineae (see Simonsen 1979) and especially to those of the family Biddulphiaceae, and is possibly the oldest known taxon that could be assigned to it. Structures such as ocelli could not be discerned. No internal costae separating the central elevation and the adjacent depression were observed in the specimen seen in girdle view (Pl. 18, Fig. 7). The circular shadow seen in LM-observation (Pl. 18, Fig. 6) is caused by the steep margin of the central elevation.

Remarks. This species occurs only rarely in the studied sample material and only few specimens were observed in LM. During the SEM investigations we encountered only one fragment consisting of one polar portion (Pl. 18, Fig. 9). Further SEM and LM studies are in progress to determine the variability of this taxon, and the structure of valves, especially the central ring of scissurate-haplo processes.

\section{GLADIOPSIS Gersonde and Harwood, gen. nov.}

Description. Valve cylindrical with moderately long pervalvar axis. Valve face circular with central sipho-shaped process. Valve face and valve mantle pseudoloculate, except in the area of the sipho-shaped process. Pseudoloculate portion of valve face may be slightly convex or truncated, area of sipho-shaped process flat. Margin of valve face may be ringed by corona of short spines.

Type species. Gladiopsis speciosa (Ŝchulz) Gersonde and Harwood, comb. nov.

Remarks. We propose the transfer of the taxa belonging to Gladius Schulz (1935) to the new genus Gladiopsis. Gladius Schulz (1935, p. 391 , pl. 1, figs. 6-8) was described from sediment enclosed in Upper Cretaceous sponges from the Gulf of Gdansk, with $G$. speciosus as its only species. However, Gladius Schulz is a later homonym of Gladius Forti and Schulz (1932). Gladius Forti and Schulz (1932) was described from Albian phosphorite nodules in northwest Germany, with G. antiquus as its only species (see remarks to the genus Gladius, below). Thus, Gladius Schulz has to be considered as an illegitimate name and to be replaced.

The new genus Gladiopsis includes: (1) Lower Cretaceous taxa bearing a rudimentary apical linking apparatus represented by a corona of short spines or spinulae situated at the margin of the valve face $(\mathrm{Pl} .11$, Figs. 1, 3-8); and (2) Late Cretaceous taxa identified by Schulz (1935) as Gladius that are lacking a rudimentary apical linking apparatus. It is speculated that Lower Cretaceous Gladiopsis species bearing a rudimentary linking apparatus evolve into Upper Cretaceous species lacking such structures (Gladiopsis lagenoides into $G$. speciosa, and $G$. modica into G. ellipsoideus).

By the transference of Gladius Schulz to Gladiopsis we hope to conclude the confusion around the generic name Gladius.

Gladiopsis lagenoides Gersonde and Harwood, sp. nov. (Pl. 10, Figs. 10, 11; Pl. 11, Figs. 6-8; Pl. 17, Fig. 1)

Description. Valve cylindrical with moderately long and straight pervalvar axis, $50-70 \mu \mathrm{m}$ in height. Presence of central process indicates colony formation. Observed girdle bands open, with punctate striae, pores arranged in slightly curved vertically oriented rows (18-20 pores in $10 \mu \mathrm{m}$, Pl. 11, Fig. 6). Valves constricted below the apex, resulting in a capitate apex. Transverse valve diameter below constriction is equal or larger than valve face diameter $(10-26 \mu \mathrm{m})$. Valve face circular, 8-20 $\mu \mathrm{m}$ in diameter, flat. Sipho-shaped process covers most of valve face (PI. 11,
Figs. 6, 7). Rudimentary pseudoloculate structure at valve face margin, with corona of short spines (PI. 11, Figs. 6-8). Valve mantle pseudoloculate. Pseudoloculi arranged in irregular diagonal rows that spiral around the valve. Shape of pseudoloculi hexagonal, 4.5-6.5 in $10 \mu \mathrm{m}$. Basal siliceous layer of valve mantle with vertically oriented punctate striae in quincunx pattern (16-20 pores in $10 \mu \mathrm{m})$.

Holotype. Friedrich-Hustedt Collection No. Zu 3/87 (Pl. 10, Figs. $10,11)$.

Type locality. Weddell Sea margin, Dronning Maud Land coast, Antarctica, ODP Site 693.

Type level. Marine late Aptian-early Albian, ODP Sample 113-693B$19 \mathrm{X}-4,77-78 \mathrm{~cm}$.

Derivation of name. lagenos (Gk.)-bottle

Other occurrences. An unconfirmed report from the Aptian/Albian in Queensland, Australia by Harper (unpublished).

Discussion. Gladiopsis lagenoides has close affinities to Gladiopsis speciosa (Schulz) Gersonde and Harwood, described from sediment enclosed in Upper Cretaceous sponges recovered in the Gulf of Gdansk. $G$. lagenoides differs from $G$. speciosa by its circle of spines situated at the valve face margin, interpreted as rudimentary linking spines. We speculate that $G$. speciosa evolved from $G$. lagenoides.

\section{Gladiopsis modica Gersonde and Harwood, sp. nov.} (Pl. 10, Figs. 12, 13; Pl. 11, Figs. 1-3)

Description. Valve cylindrical, short. Pervalvar axis straight and 20$55 \mu \mathrm{m}$ in length. Presence of central process indicates colony formation. Observed girdle band closed, with vertically oriented punctate striae (17-26 pores in $10 \mu \mathrm{m})$. Valve face circular and more or less truncated (9-32 $\mu \mathrm{m}$ in diameter), with central sipho-shaped process (6-12 $\mu \mathrm{m}$ in diameter). The rest of valve face with pseudoloculate structure and a basal layer with punctate striae. Valve margin with corona of spinulae (Pl. 11, Figs. 1, 3). Valve mantle straight and pseudoloculate. Hexagonal pseudoloculi (5-8 in $10 \mu \mathrm{m})$ arranged in irregular diagonal rows that spiral around the valve. Basal siliceous layer of valve mantle with vertical punctate striae in quincunx pattern (30-40 pores in $10 \mu \mathrm{m})$.

Holotype. Friedrich-Hustedt Collection No. Zu 3/94 (PI. 10, Figs. $12,13)$.

Type locality. Weddell Sea margin, Dronning Maud Land coast, Antarctica, ODP Site 693.

Type level. Marine late Aptian-early Albian, ODP Sample 113-693B$19 \mathrm{X}-4,103-104 \mathrm{~cm}$.

Derivation of name. modicus (Lat.)-simple

Discussion. Gladiopsis modica differs from $G$. lagenoides by its valve shape and the broad marginal valve face area with pseudoloculate structure. Many individual valves were still connected to a closed girdle band. We encountered one specimen with an apical corona of long spines (Pl. 11, Figs. 4 and 5). This form will be described after documentation of more specimens.

Gladiopsis modica has close affinities to Gladiopsis ellipsoidea $\mathrm{sp}$. nov., originally described as Pyxilla speciosa Schulz f. ellipsoidea Strel'nikova (1966, p. 35, pl. 3, fig. 1-4) from Campanian diatomaceous claystones, recovered in a drillhole located on the eastern slope of the sub-polar Ural mountains (Tyumen province). G. modica differs from G. ellipsoidea by its circle of spines situated at the valve face margin (interpreted as rudimentary linking spines), and the less convex valve face. We speculate that $G$. ellipsoidea evolved from $G$. modica.

\section{Nomenclatural Changes}

Remarks. In the following, only those Upper Cretaceous taxa are transferred to the new genus Gladiopsis that, based on their description and illustration, can be attributed to the forms described by Schulz (1935) as Gladius. Other taxa identified as Gladius, such as Gladius speciosus Schulz f. aculeolatus Strel'nikova (1974, p. 105, pl. 51, figs. 511) and G. speciosus Schulz f. porata Strel'nikova (1974, p. 106, pl. 49, fig. $22 ; \mathrm{pl} .51$, figs. 11,12 ) should probably be placed into the genus Rhynchopyxis because their apical process is different from the siphoshaped process. Taxa described as Gladius Forti and Schulz antarcticus Harwood $(1988$, p. 81, fig. 11.1, 2) and Gladius Forti and Schulz antarcticus f. alta Harwood $(1988$, p. 81 , figs. $11,3-5,7-10 ; 12.25)$ that were recovered from the Campanian and Maestrichtian of Seymour Island (eastern Antarctic Peninsula) do not belong to the genus Gladius Forti and Schulz because they bear a central process that is possibly close to a sipho-shaped process, and lack an apical linking apparatus. However, they also differ from Gladiopsis by their distinct low mantle, 
thus disc-shaped valve. Further study of the valve structure of the discshaped taxa described by Harwood (1988), and probably similar taxa identified as Coscinodiscus morenoensis Hanna (1927, p. 18, pl. 2, figs. $3,4)$, and Coscinodiscus centroaculeatus Strel'nikova (1971, p. 46, pl. 1, figs. 9-11), is needed to clarify their systematic position. It might be speculated, that Late Cretaceous taxa such as Gladius antarcticus Harwood have relationships with taxa of Praethalassiosiropsis or taxa that evolved from it.

Gladiopsis ellipsoidea Gersonde and Harwood, sp. nov.

Basionym. Pyxilla speciosa f. ellipsoidea Strel'nikova, 1966, p. 35, pl. 3, figs. 1-4.

Synonym. Gladius speciosus f. ellipsoideus Strel'nikova, 1974, p. 105, pl. 49 , figs. $1,12,13,16,17,19$.

Gladiopsis jouseana (Hajós) Gersonde and Harwood, comb. nov.

Basionym. Gladius jouseanus Hajós in Hajós and Stradner 1975, p. 932, pl. 11, figs. 7-12.

Gladiopsis maxima (Hajós) Gersonde and Harwood, comb. nov.

Basionym. Gladius maximus Hajós in Hajós and Stradner 1975, p. 933, pl. 11, fig. 13.

Gladiopsis pacifica (Hajós and Stradner) Gersonde and Harwood, comb. nov.

Basionym. Gladius pacificus Hajós and Stradner 1975, p. 933, pl. 11, figs. 1, 2; pl. 26, fig. 2 .

Gladiopsis pacifica f. minor (Hajós) Gersonde and Harwood, comb. nov.

Basionym. Gladius pacificus f. minor Hajós in Hajós and Stradner 1975 , p. 933 , pl. 11 , figs. 3,4 .

Gladiopsis speciosa (Schulz) Gersonde and Harwood, comb. nov.

Basionym. Gladius speciosus Schulz, 1935, p. 391, pl. 1, fig. 6-8. Synonyms. Pyxilla speciosa (Schulz) Strel'nikova, 1966, p. 34, pl. 2, figs. $1-7$; pl. 3 , figs. $5-9$; pl. 4 , figs. $1,2,10$. Other synonyms are cited by Strel'nikova $(1974$, p. 104,105$)$ and by Glezer et al. $(1988$, p. 55).

Remarks. A good SEM photograph of $G$. speciosa and its apical sipho-shaped process is in Glezer et al. (1988, pl. 36, figs. 6, 7).

\section{GLADIUS Forti and Schulz, 1932}

Description. Valve cylindrical with elongated pervalvar axis. Pervalvar axis straight or slightly curved. Mantle with pseudoloculate wall structure and basal siliceous layer of radial punctate striae. Valve face circular, convex, with siliceous layer of radial punctate striae. Marginal zone of valve face can be pseudoloculate. Valve face covered by strongly silicified linking apparatus for chain formation, with 2-4 radially oriented three-buttressed linking spines and equal number of corresponding scrobisculi.

Type species. Gladius antiquus Forti and Schulz, 1932

Remarks. The genus Gladius was first described by Forti and Schulz (1932) from Albian deposits in northwest Germany, G. antiquus Forti and Schulz being its only species. Gladius Schulz (1935), with $G$. speciosus as its only species, is a later homonym. This came from sediment enclosed in Upper Cretaceous sponges from the Gulf of Gdansk. It differs from G. antiquus in valve outline, presence of an apical process and the lack of an apical linking apparatus with spines and corresponding scrobisculi. G. speciosus Schulz and other taxa that had been added to the genus were transferred by Strel'nikova (1966) to Pyxilla Greville. Later, Strel'nikova (1974) retransferred the taxa to Gladius Schulz and more recently $G$. antiquus Forti and Schulz was also included (Glezer et al., 1988). We propose the transfer of the taxa belonging to Gladius Schulz to the new genus Gladiopsis (see above).

Gladius antiquus Forti and Schulz

(Pl. 7, Figs. 1, 2; Pl. 8, Figs. 1, 2, 5, 6; Pl. 15, Figs. 6, 7 ,

$$
\text { Pl. 17, Fig. 12) }
$$

Original description. Forti and Schulz, 1932, p. 242, text-fig. 3, table 3 , fig. 6 .
Description. Valve cylindrical with strongly elongated pervalvar axis, up to $420 \mu \mathrm{m}$ in height (excluding linking spines). Pervalvar axis straight to slightly curved. Presence of apical linking apparatus indicates chain formation. Girdle not observed. Transverse axis narrow $(4-10 \mu \mathrm{m}$ in diameter) and slightly decreasing in size toward the edge of the mantle. Apical part of valve with bulbous inflation (diameter 6-20 $\mu \mathrm{m}$ ). Valve face circular, slightly convex, with basal siliceous layer of radial punctate striae and a strongly silicified fork-like linking apparatus covering most of the valve face (Pl. 7, Fig. 1; Pl. 8, Fig. 6). Marginal part of valve face can be ornamented by pseudoloculate thickenings connected to basal parts of linking apparatus (Pl. 8, Fig. 2). Valve face separated from mantle by more or less distinct marginal ridge. Valve mantle with pseudoloculate structure. Pseudoloculi arranged in regular horizontal and diagonal rows that spiral around the valve. Shape of pseudoloculi hexagonal, slightly elongated in pervalvar direction except on apical inflation, 6-10 pseudoloculi in $10 \mu \mathrm{m}$. Depth of pseudolocular walls equal along the entire valve mantle. Basal siliceous layer of mantle composed of vertically oriented punctate striae in quincunx pattern (25-30 pores in $10 \mu \mathrm{m})$. Linking apparatus consisting of two radially arranged threebuttressed linking spines of equal length connected at their base by a well developed costa, and two three-winged scrobisculi situated on the marginal ridge. Scrobisculi and spines are located approximately at right angles. Length of linking spines 8-20 $\mu \mathrm{m}$.

Neotype. Friedrich-Hustedt Collection No. Zu 3/87 (Pl. 7, Figs 1, 2).

Type locality. Weddell Sea margin, Dronning Maud Land coast, Antarctica, ODP Site 693.

Type level. Marine late Aptian-early Albian, ODP Sample 113-693B$19 \mathrm{X}-4,77-78 \mathrm{~cm}$.

Other occurrences. Albian of northwest Germany (Forti and Schulz, 1932), Aptian/Albian in Queensland Australia by Harper (unpublished).

Remarks. In some individuals we noted the presence of a pore-like structure situated on the mantle 2-4 horizontal pseudoloculi rows from the marginal ridge. The nature of this structure is not yet clear. Because the original material, including the holotype of Gladius antiquus described by Forti and Schulz (1932), is missing, we designate a neotype for the species. Two varieties are defined, which differ from the type variety by the outline of the apical part of the valve mantle.

Gladius antiquus var. tenuis Gersonde and Harwood, var. nov. (Pl. 7, Figs. 3, 4, 10, 11, 15; Pl. 8, Figs. 3, 4, 7)

Diagnosis. Differs from $G$. antiquus by the apical part of its valve mantle, which is straight or slightly inflated.

Holotype. Friedrich-Hustedt Collection No. Zu 3/84 (PI. 7, Figs. 3 and 4).

Type locality. Weddell Sea margin, Dronning Maud Land coast, Antarctica, ODP Site 693

Type level. Marine late Aptian-early Albian, ODP Sample 113-693B$19 X-4,77-78 \mathrm{~cm}$.

Derivation of name. tenuis (Lat.)-thin, narrow

Other occurrences. Albian of northwest Germany (Forti and Schulz 1932).

Remarks. Forti and Schulz (1932) interpret this variety as representing an early ontogenetic state of $G$. antiquus, an interpretation that cannot be followed.

Gladius antiquus var. nodosus Gersonde and Harwood, var. nov. (Pl. 7, Fig. 9)

Diagnosis. Differs from G. antiquus by its pervalvar elongated, nonbulbous inflation of the apical part of the valve mantle.

Holotype. Friedrich-Hustedt Collection No. Zu 3/89 (Pl. 7, Fig. 9).

Type locality. Weddell Sea margin, Dronning Maud Land coast, Antarctica, ODP Site 693.

Type level. Marine late Aptian-early Albian, ODP Sample 113-693B$19 \mathrm{X}-4,77-78 \mathrm{~cm}$

Derivation of name. nodus (Lat.)-bulge

Gladius perfectus Gersonde and Harwood, sp. nov.

(Pl. 4, Fig. 18; Pl. 15; Figs. 3, 8; Pl. 19, Figs. 11-13)

Description. Valve cylindrical, stout, with straight pervalvar axis, $15-30 \mu \mathrm{m}$ in height (excluding linking spines). Presence of apical linking apparatus indicates chain formation. Girdle not observed. Valve face circular, slightly convex (30-70 $\mu \mathrm{m}$ in diameter), with radially punctate striae $(\sim 26-30$ pores in $10 \mu \mathrm{m})$ and 3-6 radially oriented costae, which 
meet in the valve center (Pl. 4, Fig. 18, Pl. 15, Figs. 3, 8; Pl. 19, Figs. 11-13). Costae spaced equally from each other at $120^{\circ}, 90^{\circ}, 72^{\circ}$, or $60^{\circ}$, depending on number of costae. Costae are bifurcated near the valve face margin and coalesce with an elongated three-buttressed linking spine at the point of bifurcation. Valve face separated from valve margin by a well-developed marginal ridge, projecting at approximately a right angle from the valve surface and strutted by pseudoloculate structure on valve mantle side (Pl. 19, Figs. 11-13). Mantle straight with pseudoloculate structure in regular horizontal and diagonal rows. Shape of pseudoloculi hexagonal, 4-6 in $10 \mu \mathrm{m}$ (Pl. 19, Figs. 11, 12). Mantle edge narrow and hyaline. Linking apparatus consisting of 3-6 three-buttressed elongated spines situated at the point of bifurcation of costae. Length of spines $30-50 \mu \mathrm{m}$. Scorbisculi small, consisting of triangular fan-like structures ("tulip flower" structure) attached to the value face with its narrow base near end of a costa close to the marginal ridge (Pl. 19, Figs. 11, 12). Scrobisculi often broken off at their point of attachment and in most cases not detectable by LM-study.

Holotype. Friedrich-Hustedt Collection No. Zu 3/98 (PI. 15, Fig. 3).

Type locality. Weddell Sea margin, Dronning Maud Land coast, Antarctica, ODP Site 693.

Type level. Marine late Aptian-early Albian, ODP Sample 113-693B$19 \mathrm{X}-4,103-104 \mathrm{~cm}$.

Gladius rhizophorus Gersonde and Harwood, sp. nov. (Pl. 7, Figs. 12-14; Pl. 9, Figs. 5-7)

Description. Valve cylindrical with moderately elongate pervalvar axis, individual valves $24-30 \mu \mathrm{m}$ in height (excluding linking spines). Pervalvar axis straight. About midway between valve face and mantle edge, a transverse constriction of the valve mantle ( $1 / 2$ to $1 / 3$ of the diameter of valve face) leads to a goblet-like valve shape. Presence of apical linking apparatus indicates chain formation. Girdle not observed. Valve face circular, slightly convex (14-25 $\mu \mathrm{m}$ in diameter), with radial punctate striae (28-32 pores in $10 \mu \mathrm{m}$ ) and a solid linking apparatus. Valve face separated from valve margin by well developed marginal ridge, projecting at an approximate right angle from valve surface and strutted by pseudoloculate structure on the valve mantle side (Pl. 9, Figs. 5, 7). Pseudoloculate structure of valve mantle in horizontal and diagonal rows that spiral around the valve. Shape of pseudoloculi hexagonal, 6-8 in $10 \mu \mathrm{m}$, smaller near mantle edge. Basal siliceous layer with punctate striae in the apical section of the valve mantle, solid below (Pl. 9, Fig. 6). Mantle edge narrow and hyaline. Linking apparatus consisting of two well developed centrally situated three-buttressed linking spines connected at their base and forming an elongated fork-like structure, and two triangular scrobisculi situated on the marginal ridge at right angles to the linking spine axis. Linking spines diverge from base of linking apparatus and then bend abruptly at $1 / 2$ to $1 / 3$ of the spine length to become parallel to the pervalvar axis. Multifurcated costae spread over the valve face resembling roots, from the base of the distal wings of the linking spines. Linking spines of equal length, $25-28 \mu \mathrm{m}$.

Holotype. Friedrich-Hustedt Collection No. Zu 3/95 (PI. 7, Figs. 13, 14).

Type locality. Weddell Sea margin, Dronning Maud Land coast, Antarctica, ODP Site 693.

Type level. Marine late Aptian-early Albian, ODP Sample 113-693B$19 \mathrm{X}-4,77-78 \mathrm{~cm}$.

Derivation of name. rhiza (Gk.)-root; phora (Gk.)-bear

Remarks. Gladius rhizophorus is the only species with a differentiated basal siliceous layer, perforated in the apical half of the valve and solid in the basal half. We also encountered one partly broken specimen with a valve face and linking apparatus comparable to those of $G$. rhizophorus, but with a straight, non constricted valve mantle. This form will be described after examination of more specimens.

Gladius trispinosus Gersonde and Harwood, sp. nov. (Pl. 7, Figs. 5, 6; Pl. 9, Figs. 1, 2; Pl. 17, Figs. 10, 11; Pl. 19, Figs. 9, 10)

Description. Valve cylindrical with moderately elongated pervalvar axis, individual valves up to $40-70 \mu \mathrm{m}$ in height (excluding linking spines). Pervalvar axis straight. Presence of apical linking apparatus indicates chain formation. Valve face circular (15-25 $\mu \mathrm{m}$ in diameter), slightly convex, with radial punctate striae (23-25 pores in $10 \mu \mathrm{m}$ ) and strongly silicified linking apparatus covering more than $1 / 2$ of the valve face (PI.
9, Fig. 2). Marginal part of valve face can be ornamented by pseudoloculate thickenings connected to basal parts of linking apparatus (diameter at base $10-15 \mu \mathrm{m}$ ). Valve face and valve mantle not separated by marginal ridge (Pl. 9, Figs. 1, 2). Valve mantle with pseudoloculate structure (5-7 pseudoloculi in $10 \mu \mathrm{m}$ ). Valve mantle with one or more constrictions in its middle portion leading to a bulbous to elongated inflation of the apical part of the valve mantle. Transverse diameter at valve mantle edge equals more or less the diameter of valve face. Pseudoloculi hexagonal, arranged in regular horizontal and diagonal rows that spiral around the valve. Pseudolocular walls at apical part of valve mantle less developed. Basal siliceous layer of mantle consists of vertically oriented punctate striae in quincunx pattern (23-25 pores in $10 \mu \mathrm{m})$. Mantle edge with narrow "Ringleiste". Linking apparatus on valve face consisting of three radially arranged three-buttressed tapering linking spines and three slit-like scrobisculi, spaced equally apart at $120^{\circ}$. Inside of spine tip with serrate ornamentation (PI. 9, Figs. 1, 2). Length of linking spines up to $15-20 \mu \mathrm{m}$.

Holotype. Friedrich-Hustedt Collection No. Zu 3/91 (Pl. 19, Figs. $9,10)$.

Type locality. Weddell Sea margin, Dronning Maud Land coast, Antarctica, ODP Site 693.

Type level. Marine late Aptian-early Albian, ODP Sample 113-693B$19 \mathrm{X}-4,77-78 \mathrm{~cm}$.

Derivation of name. tri (Lat.)-three; spinosus (Lat.)-spined

Discussion. G. trispinosus is close to G. antiquus var. antiquus and G. antiquus var. nodosus. It differs from the latter taxa by a generally shorter pervalvar axis, the lack of a marginal ridge structure, the straight slit-like scrobisculi, and the trispinose linking apparatus.

Gladius trispinosus var. tenuis Gersonde and Harwood, var. nov. (Pl. 7, Figs. 7, 8; Pl. 9, Figs. 3, 4; Pl. 17, Figs. 2-4; Pl. 19, Figs. 1, 2)

Diagnosis. Differs from var. trispinosus by its straight mantle outline, diameter of valve $10-20 \mu \mathrm{m}$. Observed girdle band with punctate striae, pores arranged in regular vertical and diagonal rows (24-25 pores in $10 \mu \mathrm{m}$ ), girdle band with hyaline edge (Pl. 9, Fig. 3).

Holotype. Friedrich-Hustedt Collection No. Zu 3/89 (Pl. 19, Figs.

Type locality. Weddell Sea margin, Dronning Maud Land coast, Antarctica, ODP Site 693.

Type level. Marine late Aptian-early Albian, ODP Sample 113-693B$19 \mathrm{X}-4,77-78 \mathrm{~cm}$.

Derivation of name. tenuis (Lat.) - thin, narrow

KERKIS Gersonde and Harwood gen. nov.

Description. Valve elliptic with bipolar symmetry. Valve face with siliceous layer of radially oriented punctate striae. Valve mantle pseudoloculate. Valve face with linking apparatus consisting of two linking spines and corresponding scrobisculi located near and at the poles, respectively. Well developed pseudoseptum (Pl. 10, Fig. 1).

Type species. Kerkis bispinosa Gersonde and Harwood, sp. nov.

Derivation of name. kerkis (Gk.) - shuttle

Kerkis bispinosa Gersonde and Harwood, sp. nov.

(Pl. 3, Figs. 6, 9; Pl. 10, Figs. 7, 16)

Description. Valve elliptic with bipolar symmetry. Length of apical axis $50-80 \mu \mathrm{m}$, length of transapical axis $12-20 \mu \mathrm{m}$. Pervalvar axis straight. Valve face undulate, central portion of valve face depressed, polar portions elevated. Each elevation furnished with a solid three-buttressed linking spine. Spines coalesce at their base with costae, one costa elongated into the central part of valve face (Pl. 3, Fig. 9). Ornamentation of valve face by radial punctate striae $(\sim 25$ pores in $10 \mu \mathrm{m})$. Valve face separated from valve mantle by marginal ridge that is well developed in the central portion of the valve where the valve face is depressed. Valve mantle steep, at its apical part smoothly following the undulation of the valve face plane and slightly curved downward at its base. Height of mantle $12-28 \mu \mathrm{m}$ at the polar elevations, $10-18 \mu \mathrm{m}$ at the central depression. Valve mantle with pseudoloculate structure. Pseudoloculi arranged in slightly curved rows, size of pseudoloculi not regular (5-7 in $10 \mu \mathrm{m}$ ). Basal layer of valve mantle with punctate striae. Edge of valve mantle narrow and hyaline. Well developed pseudoseptum in basal plane of mantle. Linking apparatus consisting of two elongated 
linking spines, $30-40 \mu \mathrm{m}$ in length, and two corresponding scrobisculi. Scrobisculi triangular openings located on the valve margin at the valve poles (Pl. 3, Fig. 9)

Holotype. Friedrich-Hustedt Collection No. Zu 3/98 (Pl. 10, Fig. 7). Type locality. Weddell Sea margin, Dronning Maud Land coast, Antarctica, ODP Site 693.

Type level. Marine late Aptian-early Albian, ODP Sample 113-693B$19 \mathrm{X}-4,103-104 \mathrm{~cm}$.

Remarks. Only small numbers of Kerkis bispinosa were encountered so that the variability of species could not be determined on a broad base. Additionally, we rarely recovered a specimen that also can be attributed to Kerkis (Pl. 10, Figs. 8, 9). This species will be described after documentation of more specimens of that type.

\section{KREAGRA Gersonde and Harwood gen. nov.}

Description. Valves circular and highly convex with apical linking apparatus composed of 2-3 buttressed spines. Spines are formed by the convergence of three or more costae that taper to a point. Valve covered by fine pores arranged in vertical rows that radiate from a central point beneath the linking apparatus. Costae continue from the base of the linking apparatus along the valve toward the valve margin.

Type species. Kreagra forfex Gersonde and Harwood sp. nov.

Derivation of name. kreagra (Gk.) - fork

Remarks. Due to the fact that most specimens are broken, with only the strongly silicified linking apparatus and the top of the conical valve face preserved, taxa within Kreagra are distinguished by the nature of their linking apparatus, including spine ornament and form, and the presence or absence of a central linking notch. Diameter of valve at point of contact with adjacent frustule can be inferred from the distance between spine tips. This is important in species where only the linking apparatus and/or the top of valve face is known.

Kreagra bifalcata Gersonde and Harwood, sp. nov. (Pl. 16, Fig. 6)

Description. Shape and structure of valve face and margin is unknown. Linking apparatus consists of two sickle-shaped linking spines that diverge from the base of the linking apparatus at $60^{\circ}-80^{\circ}$ and then turn inward toward the other spine with maximum curvature at $2 / 3$ length of spine. Distance from spine tip to base of linking apparatus is within $100-130 \mu \mathrm{m}$. Maximum breadth of linking spines is $12 \mu \mathrm{m}$, at point of greatest curvature. Each spine is constructed from four perpendicular costae. Two of these lie within the plane of the linking apparatus. The outer costa is the broadest of the four and bears a weakly serrate ornament. The other two costae are located on the inner edge of the spine and arise from a central position, just above the base of the linking apparatus. All four costae continue to the spine apex. The broad and serrate outer costa continues downward from the base of the linking apparatus onto the valve face for an unknown distance.

Holotype. Friedrich-Hustedt Collection No. Zu 3/97 (Pl. 16, Fig. 6).

Type locality. Weddell Sea margin, Dronning Maud Land coast, Antarctica, ODP Site 693.

Type level. Marine late Aptian-early Albian, ODP Sample 113-693B$19 \mathrm{X}-4,77-78 \mathrm{~cm}$.

Derivation of name. bi (Lat.)-two; falcatus (Lat.)-sickle-shaped

Remarks. Although the structure of the valve face is not known, it probably resembles that of other Kreagra species in being highly convex and finely punctate. A minimum diameter for the valve $(60-90 \mu \mathrm{m})$ can be inferred from the distance between the spine tips, assuming the tips were in contact with adjacent frustules. $K$. bifalcata is distinct from other species of Kreagra by (1) the broadly arcuate linking spines; (2) the position of transverse costae on the inner margin of the linking spines, rather than on the outer margin. $K$. bifalcata bears some affinities with $K$. trinaxon in that the outer costa is single and not paired as it is in $K$. forfex and $K$ sp. A.

Kreagra forfex Gersonde and Harwood, sp. nov. (Pl. 16, Figs. 3-5, 8-11)

Description. Valve highly convex; valve face covered with fine, circular pores arranged in discontinuous vertical rows that appear to radiate from a central point. Large hyaline linking apparatus consists of two linking spines and a broad plate that joins the two spines and contains a linking notch. Linking notch located at the apex of the hyaline plate and is constructed of two teeth and a central groove that is present on both sides of the plate. A hyaline band circles the valve near the margin and connects with the linking apparatus by four vertical extensions of the hyaline band that develop into costae. These four costae continue along the outer margins of the linking spines as a pair of costae, which support the spine. The third costa which constitutes part of the plate, is modified at the central portion of the apparatus to form a tooth of the central notch. The circumferential hyaline band marks the upper boundary of discontinuous rows of closely spaced pores (40-60 in $10 \mu \mathrm{m})$. Size highly variable; linking apparatus dimensions range between $10-70 \mu \mathrm{m}$ width and $30-110 \mu \mathrm{m}$ height.

Holotype. Friedrich-Hustedt Collection No. Zu 3/95 (Pl. 16, Fig. 3).

Type locality. Weddell Sea margin, Dronning Maud Land coast, Antarctica, ODP Site 693.

Type level. Marine late Aptian-early Albian, ODP Sample 113-693B$19 \mathrm{X}-4,77-78 \mathrm{~cm}$.

Derivation of name. forfex (Lat.)-forceps

Other occurrences. Unconfirmed reports from the Aptian/Albian in Queensland, Australia (Harper, unpubl. data).

Remarks. Chain formation is achieved through three points of contact: two points where the spine tips touch the adjacent frustule near the hyaline band, and at the central notch, where two teeth fit within the slots at either side of the siliceous plate.

\section{Kreagra forfex forma serrata Gersonde and Harwood, f. nov.} (Pl. 16, Fig. 2)

Diagnosis. This form differs from $C$ forfex f. forfex by the serrate ornamentation on each of the paired costae that continue from the hyaline band and along the outside margin of both of the linking spines.

Holotype. Friedrich-Hustedt Collection No. Zu 3/98 (Pl. 16, Fig. 2).

Type locality. Weddell Sea margin, Dronning Maud Land coast, Antarctica, ODP Site 693.

Type level. Marine late Aptian-early Albian, ODP Sample 113-693B19X-4, 103-104 cm.

Derivation of name. serratus (Lat.) - serrate

Kreagra tripartita Gersonde and Harwood, sp. nov. (Pl. 16, Fig. 1)

Description. Valve highly convex; covered with small pores arranged in discontinuous longitudinal rows; linking apparatus consists of three linking spines spaced at $120^{\circ}$ separation. Linking spines composed of three costae of equal width, two on outer margin of spine continuing down valve face as weakly developed costae. Some specimens show slightly serrate ornamentation on the linking spines. Linking spines diverge from base of linking apparatus at an angle between $50^{\circ}$ and $90^{\circ}$ and then either bend abruptly at $1 / 2$ to $1 / 3$ the length of the spine to become parallel to the pervalvar axis, or, they gradually curve inward to this orientation. No central linking notch present.

Holotype. Friedrich-Hustedt Collection No. Zu 3/95 (Pl. 16, Fig. 1).

Type locality. Weddell Sea margin, Dronning Maud Land coast, Antarctica, ODP Site 693.

Type level. Marine late Aptian-early Albian ODP Sample 113-693B$19 \mathrm{X}-4,77-78 \mathrm{~cm}$.

Derivation of name. tripartitus (Lat.)-split into three

Remarks. Tips of three linking spines probably attached to an adjacent frustule. Distance between tips of linking spines suggest that base of valve was expanded (bell-shaped) at the point of attachment.

\section{Kreagra sp. A \\ (Pl. 16, Fig. 7)}

Description. Structure and shape of the valve is unknown, only few specimens were encountered that consisted of a portion of the linking apparatus. Height $65 \mu \mathrm{m}$. Four slightly serrate costae run along the length of an elongate, hyaline stalk that gradually tapers toward the apex of the linking apparatus, until it bifurcates into two linking spines. Paired costae continue along the outside margin of the linking spine. Interior costa within the plane of the linking apparatus attains a maximum breadth at the point where a simple U-shaped linking notch bisects the hyaline plate.

Discussion. This type of linking apparatus attributed to Kreagra was recovered only in few specimens. It differs from the linking apparatus of 
other species of Kreagra by the elongate hyaline stalk associated with it; the simple linking notch and teeth; and the relatively short linking spines.

\section{MICROORBIS Gersonde and Harwood, gen. nov.}

Description. Valve disc- or lens-shaped, consisting of basal layer that is punctate and striate in radial orientation. Central area often distinct, with silicified circular plate with scattered or clustered pores (punctatehaplo processes). Valve mantle low, separated from valve face by a more or less developed marginal ridge. Frustules probably heterovalvate.

Type species. Microorbis convexus Gersonde and Harwood, sp. nov.

Derivation of name. mikros (Gk.) - small; orbis (Lat.)-disc

Microorbis convexus Gersonde and Harwood, sp. nov.

(Pl. 2, Figs. 7, 8; Pl. 14, Figs. 3, 6, 9; Pl. 19, Figs. 5, 6)

Description. Valve circular, lens-shaped, weakly silicified. Valve face convex, $25-40 \mu \mathrm{m}$ in diameter, covered by dense net of radial punctate striae ( $26-30$ pores in $10 \mu \mathrm{m}$ ). The outside of valve face often covered by granulae and spinulae. Central area often distinct, with more thickly silicified central plate that is perforated by scattered punctate-haplo processes, 3-ca. 35 per central plate (Pl. 2, Figs. 7, 8; Pl. 14, Fig. 3; Pl. 19, Figs. 5, 6). Valve mantle low and steep, separated from valve face by a weakly developed marginal ridge. Punctate striae of valve face continue on valve mantle. Edge of valve mantle hyaline. 7, 8).

Holotype. Friedrich-Hustedt Collection No. Zu 3/98 (PI. 2, Figs. $5,6)$.

Paratype. Friedrich-Hustedt Collection No. Zu 3/90 (PI. 19, Figs.

Type locality. Weddell Sea margin, Dronning Maud Land coast, Antarctica, ODP Site 693.

Type level. Marine late Aptian-early Albian, ODP Sample 113-693B19X-4, 103-104 cm.

Remarks. The presence of central punctate-haplo processes may indicate that the individual cells of Microorbis convexus were connected by threads to form colonies.

Some of the observed specimens that may be related to $M$. convexus do not have a valve face center differentiated by a more thickly silicified plate perforated by punctate-haplo processes (Pl. 14, Figs. 6, 9). We also encountered diatom valves that resemble the valves of $M$. convexus in shape and punctate striation and differ by the presence of 4-12 equally spaced radial costae (Pl. 18, Figs. 1-4, 8). The costae are restricted to the outer $1 / 3$ to $1 / 2$ of the valve face and bifurcated near the valve face margin. At the point of bifurcation each costa coalesces with an elongated linking spine. Compared to $M$. convexus the valves of this taxon may have a stronger silicified central plate perforated by punctate-haplo processes. However, most specimens (except one, Pl. 18, Fig. 8) were only investigated by LM, so that a detailed analysis of valve structural patterns was not possible. Scrobisculi could not be identified on the SEM investigated specimen.

These findings indicate that the frustules of $M$. convexus were very probably heterovalvate. Ongoing further SEM and LM studies will elucidate the relationships between the different types of valves.

Microorbis undulatus Gersonde and Harwood, sp. nov. (Pl. 2, Figs. 9, 10; Pl. 14, Figs. 5, 8)

Description. Valve circular, $12-20 \mu \mathrm{m}$ in diameter, weakly silicified. Valve face convex with central depression, ornamented by punctate striae in radial orientation (22-25 pores in $10 \mu \mathrm{m}$ ). Central depressed portion of valve face (up to $1 / 2$ of valve diameter) hyaline or with scattered punctate haplo-processes. Outside of valve face sometimes covered by thickenings which, in part, are oriented with the interstriae. Valve mantle low and steep, separated from the valve face by a well developed marginal ridge. Inside of marginal ridge strutted by small thickenings. Valve mantle with punctate striae, similar to that on valve face. Valve mantle edge hyaline (PI. 14, Figs. 5, 8).

Holotype. Friedrich-Hustedt Collection No. Zu 3/83 (Pl. 2, Figs. $9,10)$.

Type locality. Weddell Sea margin, Dronning Maud Land coast, Antarctica, ODP Site 693.

Type level. Marine late Aptian-early Albian ODP Sample 113-693B$19 \mathrm{X}-4,77-78 \mathrm{~cm}$.

Remarks. The presence of central punctate-haplo processes probably indicates that the individual cells of Microorbis undulatus were connected by threads to form colonies. A minor portion of the observed specimens of $M$. undulatus have a hyaline valve face center. These forms may probably represent terminal valves of chains.

\section{PRAETHALASSIOSIROPSIS Gersonde and Harwood, gen. nov.}

Description. Genus with affinities to Thalassiosiropsis Hasle. Valve circular, disc-shaped with low valve mantle. Areolae loculate with external foramina and internal vela that have a structure close to cribra. Foramina in straight to slightly curved tangential rows. Velum pores in radial orientation (PI. 1, Figs. 5, 6). Central area with perforate process.

Type species. Praethalassiosiropsis hasleae Gersonde and Harwood, sp. nov.

Praethalassiosiropsis hasleae Gersonde and Harwood, sp. nov.

(Pl. 1, Figs. 1-9; Pl. 2, Figs. 1, 2)

Synonym? Coscinodiscus sp. Dun et al., 1901, Pl. 18, Fig. 1; ?morphotype D Haig and Barnbaum, 1978, fig. 5F.

Description. Valve circular, diameter $55-135 \mu \mathrm{m}$, approx. $2 / 3$ of the central portion of the valve face slightly elevated. Presence of central process indicates colony formation. Areolae loculate with external foramina and internal vela arranged in linear to slightly curved tangential rows in the central elevated part of the valve and more fasciculate near the margin. Areolae of uniform size over the entire valve face (3.5-5 in $10 \mu \mathrm{m})$, except near the central area and close to the margin, where they are slightly smaller $(4.5-6$ in $10 \mu \mathrm{m})$. Size of areolae positively correlated with valve diameter. Circular foramina can constrict external part of areolae up to $1 / 2$ of the areola diameter (Pl. 1, Fig. 9). Velum pores radially oriented (Pl. 1, Fig. 5), but in general not very regularly arranged (30-40 in $10 \mu \mathrm{m})$. Individual vela are not always distinguished by the pore arrangement. However the pore arrangement is close to a cribral structure. Valve mantle low, consisting of one row of areolae with an external apposition of silica, shaped like a low marginal ridge (Pl. 1, Figs. $1,4,5$ ). Perforate process in central position, 4-10 $\mu \mathrm{m}$ in diameter. Diameter of perforate process positively correlated with valve diameter (Fig. 4). No marginal processes or structures close to a labiate process have been observed. The lack of areolae in the area of the perforate process leads to a circular depression of the valve layer on the internal side of the valve (Pl. 1, Figs. 2, 3, 5, 6, 8). $1,2)$.

Holotype. Friedrich-Hustedt Collection No. Zu 3/82 (Pl. 2, Figs.

Type locality. Weddell Sea margin, Dronning Maud Land coast, Antarctica, ODP Site 693.

Type level. Marine late Aptian-early Albian, ODP Sample 113-693B$19 \mathrm{X}-4,77-78 \mathrm{~cm}$.

Derivation of name. Dedicated to Grethe Rytter Hasle, Professor of Marine Botany at the University of Oslo, Norway.

Other occurrences. Unconfirmed reports from the Aptian/Albian in Queensland, Australia by Harper (unpubl. data), Haig and Barnbaum

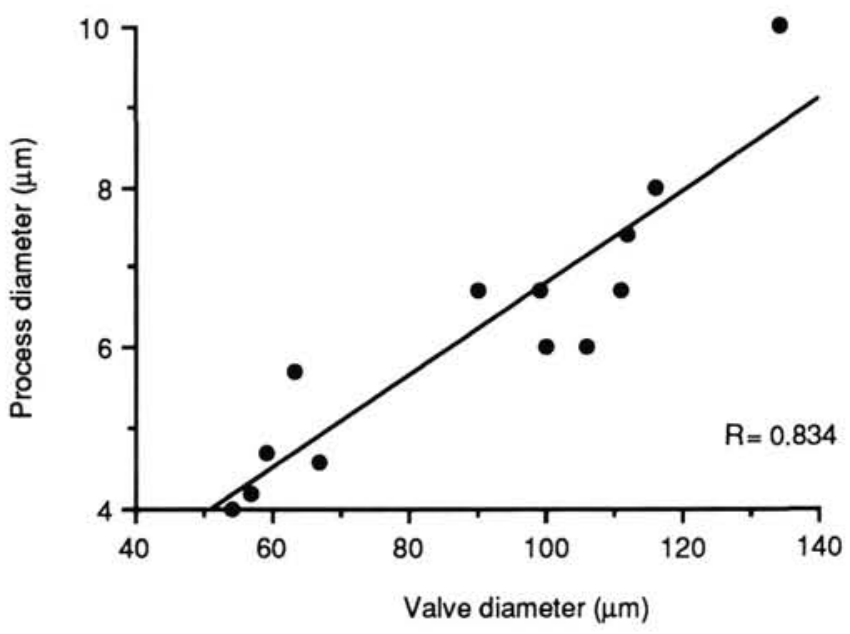

Figure 4. Correlation of valve diameter with diameter of central perforate process in Praethalassiosiropsis hasleae. 
(1978), and Dun et al. (1901), as Coscinodiscus sp., and probably from the Albian of Ilsede (northwest Germany) by Rüst (1885).

Discussion. $P$. hasleae has some affinities to Thalassiosiropsis wittiana (Pantocsek) Hasle described from Late Cretaceous and Paleocenelower Eocene deposits from Russia and California (Hasle and Syvertsen, 1985) and is perhaps a precursor of the latter species. Similarities between the two species are the structure of the valve margin, the size and general pattern of the areolae and the cribral pores. $T$. wittiana, like $P$. hasleae has radially oriented cribral pores, but the cribra are distinctly separated from each other. The size of the cribral pores in both species is rather coarse (30-40 in $10 \mu \mathrm{m})$. For this reason it might be argued that these pores do not represent true cribral pores of loculate areolae but are the internal pores of a pseudoloculate structure, as this is a common feature of most of the Cretaceous species described here. T. wittiana has a central, multistrutted process ( $=$ annular process of Nikolaev and Strel'nikova, 1987) that has some affinities to the perforate process of $P$. hasleae.

Remarks. Forti and Schulz (1935) describe a large cylindrical diatom species as Dactyliosolen priscus from the Albian in northwest Germany that, by its valve diameter (40-152 $\mu \mathrm{m})$, the slightly convex valve face, and the shape of areolae (polygonal, 3 in $10 \mu \mathrm{m}$ ), has affinities to $P$. hasleae. Based on the photographs and description, D. priscus Forti and Schulz (1932, p. 241, table 3, figs. 1-3) has a large number of girdle bands and its valve outline may be circular or elliptical. Because Forti and Schulz did not mention nor describe a distinct central structure that could represent a central process, and because the photographs of their species do not show such a structure, we believe that $D$. priscus is not the same as $P$. hasleae.

\section{RHYNCHOPYXIS Gersonde and Harwood, gen. nov.}

Description. Valve cylindrical with straight, elongated pervalvar axis. Valve face circular, with central rhyncho-shaped process. Valve face and mantle pseudoloculate.

Type species. Rhynchopyxis siphonoides Gersonde and Harwood, sp. nov.

Derivation of name. rhynchos (Gk.) - snout; pyxis (Gk.)-box

Remarks. An apical rhyncho-shaped process is probably also present in taxa originally described by Strel'nikova $(1966$, p. 35 , pl. 4, figs. 3-6, 11-12) as Pyxilla speciosa f. aculeolata and $P$. speciosa f. porata from Campanian diatomaceous claystones from the eastern slope of the subpolar Ural mountains. Later, Strel'nikova (1974, p. 105-106) transferred these taxa to Gladius Schulz. Both taxa bear an apical process that is tube-like and prolongated to the outside, $\sim 5-10 \mu \mathrm{m}$ long in $G$. speciosus f. porata and somewhat shorter in G. speciosus f. aculeolatus. However, based on photographs and the description of the apical structure of these taxa given by Strel'nikova (1966) and the only published SEM-illustration (Glezer et al., 1988, pl. 35, fig. 8, process of $G$. speciosus f. aculeolatus) we cannot definitely decide if they represent true rhyncho-shaped processes. Thus, prior to more comprehensive studies of the apical structure of Strel'nikova's taxa, we cannot decide, if these taxa have to be transferred to Rhynchopyxis.

\section{Rhynchopyxis siphonoides Gersonde and Harwood, sp. nov.} (Pl. 2, Figs. 3-6; Pl. 3, Figs. 1-3)

Description. Valve cylindrical with straight, moderately elongated pervalvar axis, $40-100 \mu \mathrm{m}$ in height including the rhyncho-shaped process. Presence of central process indicates colony formation. Girdle not observed. Valve face circular, conical and with rhyncho-shaped process at the center. Length of outer tube of process 14-20 $\mu \mathrm{m}$. Valve face and mantle pseudoloculate (Pl. 3, Figs. 1, 2). Pseudoloculate structure on valve face less developed (Pl. 2, Figs. 3-6). Basal siliceous layer punctate (25-30 pores in $10 \mu \mathrm{m}$ ), pores irregularly arranged (Pl. 3, Fig. 3). Valve face and mantle separated by a weakly developed marginal ridge (PI. 3, Figs. 1,2) or a corona of small spines. Valve mantle straight, pseudoloculi 4-7 in $10 \mu \mathrm{m}$, arranged in regular and irregular tangential rows that spiral around the valves. Edge of valve mantle narrow with "Ringleiste". 3, 4).

Holotype. Friedrich-Hustedt Collection No. Zu 3/83 (Pl. 2, Figs.

Type locality. Weddell Sea margin, Dronning Maud Land coast, Antarctica, ODP Site 693.

Type level. Marine late Aptian-early Albian, ODP Sample 113-693B$19 \mathrm{X}-4,77-78 \mathrm{~cm}$.

Derivation of name. siphon (Gk.)-syringe
Other occurrences. Unconfirmed report by Rüst (1885) from the ?Albian near Ilsede (labelled as a tintinnid).

Remarks. Isthmia fortii Forti and Schulz, an elongated, cylindrical diatom species with a linking structure, described from the Albian in northwest Germany by Forti and Schulz (1935) may, on photographic evidence (pl. 3, figs. 7, 7a, 8), have some affinities to $R$. siphonoides. However, in their description (p. 242) Forti and Schulz state that the apical linking structure is a slightly curved spine situated in eccentric position on the valve face. For this reason we do not believe that the apical linking structure described by them represents a haplo process and that I. fortii is the same as $R$. siphonoides.

Rüst (1885, pl. 44, fig. 1) illustrates a diatom, which he refers to the tintinnids, that has strong affinities with $R$. siphonoides. An elongated sipho-shaped process is obvious on Rüst's drawing. Rüst states that this form occurs abundantly in the recovered assemblage. According to Kemper (pers. comm., 1989) the assemblages studied by Rüst are very probably of Albian age, and thus not of Jurassic age as stated by Rüst (1885).

TROCHUS Gersonde and Harwood, gen. nov.

Description. Valve disc-shaped, consisting of basal layer with punctate striae in radial orientation. Valve face with radial costae that fuse in the center of the valve face. Valve face separated from valve margin by a projecting marginal ridge. Valve face with one or more slit-like structures (scissurate-haplo processes) subcentrally located. Frustules probably heterovalvate, differentiated by presence/absence of scissurate haplo-processes and structure of costae.

Type species. Trochus elegantulus Gersonde and Harwood, sp. nov. Derivation of name. trochos (Gk.)-wheel

Trochus elegantulus Gersonde and Harwood, sp. nov. (Pl. 14, Figs. 1, 2, 4, 7; Pl. 15, Figs. 1, 2, 11)

Description. Valve circular, weakly silicified, $18-63 \mu \mathrm{m}$ in diameter. Valve face with a strongly raised central part covering $\sim 1 / 2$ of valve face area. Central part of the valve face with 2-5 radial costae, which meet at its top. Costae extend $1 / 2$ to $1 / 3$ radius from center. Valve face covered by radial punctate striae ( $28-42$ pores in $10 \mu \mathrm{m})$. Striation very dense (3040 striae in $10 \mu \mathrm{m}$ ) in marginal part of the valve face, less dense on and near central raised part, the top of which is hyaline or with scattered pores. About midway between valve face center and valve margin 1-3 scissurate-haplo processes are radially oriented (Pl. 14, Fig. 7; Pl. 15, Fig. 1, 11). Valve face separated from valve margin by well developed marginal ridge ( $\mathrm{Pl}$. 14, Fig. 4), projecting at $\sim 130^{\circ}$ angle from valve surface. Structure of marginal ridge punctate, striate in radial orientation. Valve mantle at an angle of $\sim 130^{\circ}-180^{\circ}$ to the valve face, ornamented by dense punctate striae. Edge of mantle narrow and hyaline.

Holotype. Friedrich-Hustedt Collection No. Zu 3/98 (Pl. 15, Figs. $1,2)$.

Type locality. Weddell Sea margin, Dronning Maud Land coast, Antarctica, ODP Site 693.

Type level. Marine late Aptian-early Albian, ODP Sample 113-693B$19 \mathrm{X}-4,103-104 \mathrm{~cm}$.

Remarks. During our studies we also encountered valves with similar structure to those described above, but lacking scissurate processes and having radial costae that bifurcate a short distance from the center. This indicates that the frustules of $T$. elegantulus may be heterovalvate. We will try to elucidate the relationships between the different types of valves by further SEM and LM studies.

\section{DISCUSSION}

The upper Aptian-late Albian sediment sequence of Site 693 contains an extremely well preserved diatom assemblage that allows insight into a little known stage of early diatom evolution. The diatom assemblages are preserved in opaline state, and SEM investigations of the valve ultrastructure show that the valves were affected by only minor diagenetic alteration. It can be speculated that, due to the unusually good state of preservation of the recovered diatom assemblages that also allowed preservation of weakly silicified valves (e.g., Bilingua, Microorbis, and Trochus taxa), the composition of Albian-Aptian diatom assemblages that were originally produced in the area of the site is not very strongly biased. However, we suppose that some alteration 
led to the destruction of weakly silicified velum structures that may have occluded the pores of the basal siliceous layer. The original presence of such occluding structures is postulated, because the rather large size of the pores of the basal layer would not prevent effusion of cellular components.

Considering the results of Von Rad et al. (1977) the very unusual preservation of Lower Cretaceous biogenic opal might be explained by at least two factors: (1) the sediment contains high amounts of clay and is barren of calcareous components; (2) the Albian-Aptian diatomaceous sediments of Site 693 were never buried deeper than their present depth at around 398-410 mbsf (Barker, Kennett, et al., 1988, Site 693).

The recovered Albian-Aptian diatom assemblages are well diversified and consist of vegetative forms, described in the present paper, and resting spores that are reported in the companion chapter by Harwood and Gersonde (this volume). The forms described in this paper are interpreted to represent vegetative forms because of the following characteristics: (1) weakly silicified valves (Bilingua, Microorbis, and Trochus taxa); (2) relatively large volume of frustules (Gladius, Gladiopsis); (3) perforate basal siliceous layer leads to relatively "permeable" valve structure (all taxa described herein); (4) presence of connecting bands. However, we know that this interpretation is in some cases arbitrary (e.g., in cases where no connecting bands were found) considering the fact that modern resting spores often show characteristics typical of vegetative forms. But overall, there are distinct differences between the diatoms we consider to represent vegetative cells and resting spores, and considerable uniformity of structure and form within each of these two groups to warrant their division.

We document in this chapter 25 taxa in 13 genera (Table 2), all belonging to the diatom order Centrales. These taxa represent the majority of the vegetative forms encountered in the investigated diatom assemblages and most of them could be well documented by SEM and LM observations. However, a number of additional taxa with rare to trace occurrences are not yet well enough documented and will be presented and described elsewhere.

The diatom assemblages recovered at Site 693 have rather close similarities with the Aptian assemblages from Queensland, Australia, reported by Harper (unpublished notes). Most of the types illustrated by Harper can be assigned to taxa reported in the present paper (Ancylopyrgus reticulatus var. elongatus, Basilicostephanus mirabilis, Kreagra forfex, Gladius trispinosus var. tenuis, ?Gladiopsis lagenoides, ?G. modica, Praethalassiosiropsis hasleae). The resemblance to the assemblages reported by Forti and Schulz (1932) and Rüst (1885) from the Albian (Gault) in northwest Germany (Hannover area) is probably also very close. However, the documentation of these taxa does not always allow an unequivocal assignment to the diatoms encountered at Site 693. Undoubted occurrences in the German Albian are those of Gladius antiquus and Rhynchopyxis siphonoides, reported by Forti and Schulz (1932) and Rüst (1885), respectively. Uncertain are those diatoms close to Amblypyrgus campanellus, Basilicostephanus mirabilis, and some forms representing resting spores (see Harwood and Gersonde, this volume).

The number of different taxa and the diversity in diatom valve structure reported up to now from Albian and Aptian deposits indicate that during the middle Cretaceous time period, $(\sim 100-120 \mathrm{Ma})$, diatoms were already well established members of the marine phytoplankton community. All middle Cretaceous diatom assemblages found in opaline valve preservation that are now known are from neritic shallow water environments. The Albian-Aptian paleoenvironment in northwest Germany (Hannover area) is described as inshore-environment affected by alternating transgressions and regressions (Kemper et al., 1975). Based on the occurrence of calcareous micro- and megafossils,
Table 2. Diatom taxa treated in this paper. Taxa marked by an asterisk are not present in the studied upper Albian-lower Aptian diatomaceous sediment interval of Site 693 .

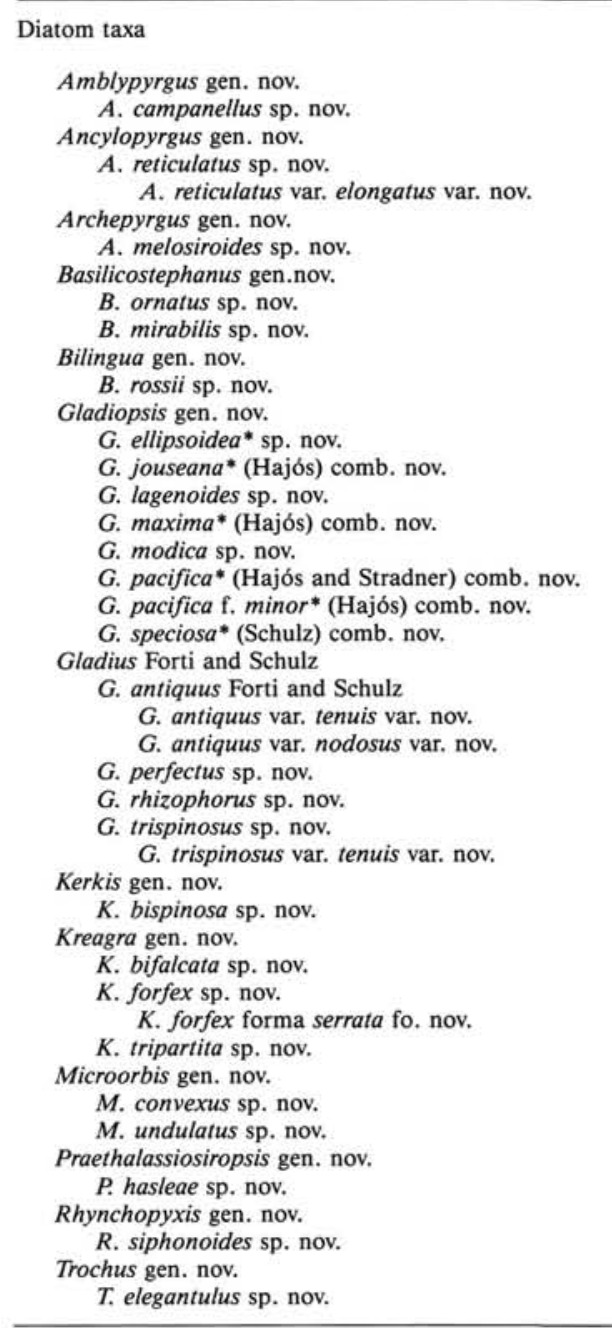

Haig and Barnbaum (1978) suggest a slightly hyposaline, shallow sea in the Early Cretaceous Artesian Basin of Australia. The species composition of the planktonic and benthic foraminifers encountered in the sediments immediately underlying the upper Aptian/lower Albian diatomaceous sediment interval also suggest a shallow water environment with water depth probably around $500 \mathrm{~m}$ and somewhat restricted conditions (Shipboard Scientific Party, 1988; Site 693).

We found it difficult to place the Albian-Aptian diatoms described in this paper into a diatom system (e.g., as proposed by Simonsen, 1979) and to relate them to circumscribed diatom suborders, families, or subfamilies. At present the structure of a diatom system is not yet fully established and is still controversial (e.g., see discussion in Ross and Sims, 1987). The system proposed by Simonsen (1979) is strongly based on the presence, location, and arrangement of labiate and strutted processes. The herein studied middle Cretaceous diatoms did not yet possess these processes, but in some species structures interpreted to represent ancestral stages of strutted and labiate processes were discerned. Another problem is that some of the families, such as the Melosiraceae, apparently represent a "huge conglomerate" (Simonsen, 1972, p. 43) of genera and thus cannot 
be characterized very well. For these reasons we decided to divided the herein described diatom taxa into groups and subgroups. We postulate that at least some of them represent major stages in diatom organization and diatom evolution. However, as far as we think it possible or useful, we will discus relationships between our groups and already defined families or other taxa of higher rank, using the system proposed by Simonsen (1979).

Major criteria for subdivision are (1) structure of the valve wall; (2) presence/absence of apical linking apparatus and location of the linking apparatus on the valve face; (3) presence/absence of structures interpreted to represent processes and morphology of these processes; and (4) valve symmetry. Some groups are not real groups because they are represented only by one taxon, but as more data become available from different localities and stratigraphic levels in the Cretaceous, these groups will probably contain more taxa. Some groups probably also represent different stages in adaptions to life habitats.

\section{Group 1}

This group is represented by taxa of Amblypyrgus, Ancylopyrgus, Basilicostephanus, Gladius, and Kerkis, with a well developed apical linking apparatus for chain formation, consisting of one or more three-buttressed linking spines and corresponding scrobisculi. Except for Kerkis bispinosa that has bipolar valve symmetry, all taxa have cylindrical frustules with a more or less elongated pervalvar axis. The valve wall consists of a basal siliceous layer with punctate striae (generally $20-25$ pores in $10 \mu \mathrm{m}$ ) that are radial on the valve face and in general vertical on the valve mantle. Except for Basilicostephanus mirabilis, the valve wall is ornamented to various degrees by a pseudoloculate structure. In some taxa the pseudoloculate structure is restricted to the valve mantle, in others it is present on both the valve mantle and the valve face, or on the valve mantle and marginal parts of the valve face. A more or less developed marginal ridge often marks the boundary between valve face and valve mantle. No processes or structures close to processes were detected, either on the valve face, or on the valve mantle.

The pseudoloculate structure can be explained as a means to increase the stability of the elongated valves, and to support the long and strongly silicified linking spines that many taxa bear on their apex. In the taxa with a valve face not covered by a pseudoloculate structure the linking spines are anchored on well silicified costae and/or a well silicified marginal ridge. The presence of the linking apparatus indicates the formation of well organized chains of cells that could also have spiral or circular forms, as indicated by the occurrence of a curved pervalvar axes. The rather complicated, diverse, and highly developed structure of the linking apparatus shows that these structures must be the result of an evolutionary development that started well before the Albian-Aptian time period.

This group is dominant in the Albian-Aptian diatom assemblages recovered at Site 693 and it was also found in AlbianAptian deposits in Australia (Harper, 1977, and unpubl. data) and northwest Germany (Forti and Schulz, 1932). Paleoenvironmental studies based on other fossil groups indicate that the diatom assemblages at these three localities lived in a nearshore shallow water marine environment (Kemper, 1975; Haig and Barnbaum, 1978; Shipboard Scientific Party, 1988). This may indicate that these chain-forming taxa represent one successful diatom group during the middle portion of the Cretaceous period that, however, was probably restricted to nearshore shallow water environments. It may be speculated that the restriction to such environments was related to the fact that these diatoms incorporate, especially in the linking apparatus, a rather large amount of silica in their wall. By this, the removal of viable frustules and chains from the euphotic zone by sedimentation to the seafloor could have been increased. Thus, these diatoms were probably restricted to environments that are shallow enough to allow resuspension of viable diatom frustules from the sediment surface into the euphotic water layer and/or that are characterized by sufficient upwelling to counteract vertical sinking.

Considering the valve symmetry, the taxa included in Group 1 can be split into two subgroups.

\section{Subgroup $1 A$}

This subgroup consists of taxa with cylindrical outline and circular valve face (Amblypyrgus, Ancylopyrgus, Basilicostephanus, Gladius). In this context we want to point out that $\mathrm{Si}$ monsen, who placed Gladius Forti and Schulz into the family Pyxillaceae Schütt (Simonsen, 1979, p. 49) apparently confused it with Gladius Schulz, replaced herein by Gladiopsis gen. nov.

\section{Subgroup $1 B$}

The subgroup is represented by only one species and it differs from the taxa of Subgroup 1A by its bipolar valve (Kerkis bispi$n o s a$ ). $K$. bispinosa occurs only rarely and is one of two species with bipolar valve symmetry found in the investigated sample set. The other species is Bilingua rossii, placed into Subgroup 3C.

We suppose that the development of the taxa of Group 1 started well before the middle Cretaceous and that these taxa are representative of an early stage of diatom evolution. It may be speculated that the diatoms reported by Rothpletz (1896) from Lower Jurassic (late Lias) deposits in southern Germany as Pyxidicula bollensis and $P$. liasica are somehow related to taxa of Amblypyrgus. Unfortunately, the deposit studied by Rothpletz can no longer be located, nor any original raw or type material, so that a modern study of that Jurassic material is not possible. Based on our investigation we doubt that the diatoms described by Rothpletz belong to the genus Pyxidicula Ehrenberg, characterized by at least one labiate process. Our skepticism is based on the fact that, during our broad SEM investigations of the ultrastructure of Lower Cretaceous diatoms, we could not detect structures that undoubtedly represent labiate processes (rimoportula). However, we observed slit-like structures, named the scissurate-haplo process, in taxa of Trochus (Subgroup 3B) and Bilingua (Subgroup 3C) that may represent an ancestral stage of the labiate process. It seems to be very likely that diatoms representing an early stage of evolution did not bear a labiate process and that the development of this structure, which was completed in the Late Cretaceous, started somewhere within the middle Cretaceous.

We speculate that Group 1 taxa were probably at the maximum of their development during the middle Cretaceous time interval and they apparently became extinct somewhere between the Albian and Campanian, because none of the taxa of Group 1 is recorded from Upper Cretaceous (Campanian, Maestrichtian) sediments according to the investigations of Hanna (1934), Schulz (1935), Strel'nikova (1974), Hajós (1974), and Harwood (1988). One reason for the extinction of the taxa of Group 1 may be the development of apical processes that take the function of the mostly heavily silicified linking apparatus. Such development can be deduced by the study of taxa included to Subgroup $2 \mathrm{~A}$ (see below). Development of apical linking processes reduced the amount of silica incorporated into the diatom wall and it may be speculated that this reduction, which leads to a reduction of the sinking velocity of the frustules, might have enabled the diatoms to populate habitats other than shallow water seas.

The occurrence of taxa with bipolar symmetry in the middle Cretaceous may indicate that the beginning of development from frustules with circular valve plane to frustules with bipolar symmetry can be placed in the middle Cretaceous time period or not long before. Development of bipolar symmetry in taxa belonging to different diatom groups (Groups 1 and 3) shows that this 
development took place in two different lines (convergent development). However, the line including Kerkis bispinosa was not successful because it apparently became extinct in the Late Cretaceous together with the other taxa of Group 1.

\section{Group 2}

Group 2 is characterized by genera (Praethalassiosiropsis, Gladiopsis, Rhynchopyxis) that bear a well developed process (perforate process, sipho-shaped process, rhyncho-shaped process) in the valve center. We suggest that Albian-Aptian diatoms of Group 2 directly evolve into Campanian-Maestrichtian diatoms.

The processes of the three genera developed by transformation of the perforated basal siliceous layer. We interpret the perforate process of Praethalassiosiropsis as representing an early stage of this development, characterized by a slightly transformed internal protrusion of the basal layer (Pl. 1, Figs. 2, 3, 5-8). The sipho- and the rhyncho-shaped processes of Gladiopsis and Rhynchopyxis are possibly more highly developed stages within the evolution of diatom processes. The internal structure of the latter two processes is similar to each other, is characterized by a solid wall, and is not occluded at its inner opening (Pl. 3, Fig. 3 ). The rhyncho-shaped process is interpreted to represent the most evolved stage of Lower Cretaceous diatom processes. Here the outer structure of the basal layer surrounding the tube of the process is closed by a silica wall and has lost its perforation (Pl. 3, Figs. 1, 2).

Structurally the Early Cretaceous processes are possibly older homologs to the multistrutted process of Hasle and Syvertsen (1985), named the annular process by Nikolaev and Strel'nikova (1987), and the strutted process (fultoportula). The adhesive function of the strutted process by extrusion of b-chitine threads was shown by Herth and Zungenmaier (1977), and Herth and Barthlott (1979). This would support our hypothesis of the adhesive function of the processes of the Lower Cretaceous species. The multistrutted process was found in the Upper Cretaceous to lower Eocene species Thalassiosiropsis wittiana (Pantocsek) Hasle. In their description Hasle and Syvertsen (1985) pointed out the similarity to the strutted process. A reduction of the silicified central area and a transformation of the multiple pores of the perforate process to a ring of larger pores situated on the marginal wall adjacent to the solid ring would result in a structure close to that of the multistrutted process (see Hasle and Syvertsen 1985, pl. 4; and Glezer et al, 1988, pl. 33, figs. 7, 8 ). The internal structure of the sipho- and the rhyncho-shaped process is a tube surrounded at its base by a number of pores (Pl. 3, Fig. 3), a structure similar to that of the multistrutted process of Hasle and Syvertsen (1985) and the strutted process as defined in Anonymous (1975). Based on this interpretation the genera Praethalassiosiropsis, Gladiopsis, and Rhynchopyxis could be placed close to the family Thalassiosiraceae Lebour, the only family characterized by the presence of strutted processes.

Considering the valve morphology, the structure of the wall and of the process, Group 2 can be divided into two subgroups.

\section{Subgroup $2 A$}

Subgroup 2A includes diatom taxa (Gladiopsis, Rhynchopyxis) that have some affinities to Subgroup 1A: (1) the frustules are cylindrical with a more or less elongated pervalvar axis; (2) the valve wall consists of a basal siliceous layer with punctate striae $(20-25$ pores in $10 \mu \mathrm{m})$ that are radial on the valve face and in general vertical on the valve mantle; (3) the valve mantle and valve face (except area of process) are ornamented by a pseudoloculate structure. These affinities may indicate some evolutionary relationships between the taxa of Subgroup 1A and those of Subgroup 2A.
As already stated above, the processes (sipho-shaped process, rhyncho-shaped process) characteristic for the taxa of Subgroup 2A show close similarities and differ from each other only by their external structure. As documented by the presence of a marginal corona of spinulae (PI. 11, Figs. 1, 3-8) in the Albian-Aptian taxa of the genus Gladiopsis that are interpreted to represent rudimentary linking spines, the development of processes supersedes the linking apparatus as an instrument for chain formation. In Late Cretaceous (Campanian-Maestrichtian) Gladiopsis taxa the reduction of the linking apparatus is apparently completed because rudimentary linking spines cannot be observed. Thus, a major morphological feature of middle Cretaceous diatom taxa was lost between the middle and Late Cretaceous.

Our study shows, that evolutionary precursors of the well established Late Cretaceous taxa of Gladiopsis and probably also of Rhynchopyxis existed in the middle Cretaceous. To our knowledge these taxa became extinct in the latest Cretaceous or near the Cretaceous-Tertiary boundary, because we are ignorant of reports from Tertiary deposits (see Harwood, 1988).

The assumption of the presence of central labiate processes in the Upper Cretaceous species of Gladius Schulz, herein transferred to the genus Gladiopsis, by Simonsen $(1979$, p. 22) is not confirmed. LM investigations of Harwood (1988) and our preliminary SEM investigations on Upper Cretaceous Gladiopsis species from Seymour Island (Antarctic Peninsula) show that their central process is in fact a sipho-shaped process.

\section{Subgroup 2B}

This subgroup is represented by only one taxon, Praethalassiosiropsis hasleae. It differs from the taxa of Subgroup $2 \mathrm{~A}$ by the disc-shaped valve, the morphology of the process, the lack of rudimentary linking spines, and the structure of the valve wall interpreted to represent a first stage of loculate areolae that have affinities to the loculi of the Thalassiosiraceae (external foramina, internal cribra). The size of pores interpreted to represent vela is distinctly finer (30-40 pores in $10 \mu \mathrm{m})$ compared to the size of pores in most of the pseudoloculate species $(20-25$ in $10 \mu \mathrm{m})$. The distinct morphology of $P$. hasleae may indicate that this genus evolved in a lineage separate from that of other Lower Cretaceous species.

P. hasleae has affinities to Thalassiosiropsis wittiana (Pantocsek) Hasle described from Upper Cretaceous and Paleocenelower Eocene deposits from Russia and California (Hasle and Syvertsen, 1985) and is perhaps a precursor of the latter species.

\section{Group 3}

Group 3 includes taxa marked by valves that consist of a weakly silicified basal siliceous layer with radial punctate striae (Bilingua, Microorbis, Trochus). Valve face and valve mantle have the same structure and are separated by a more or less developed marginal ridge. In general the valve mantle is low. The valve face can be ornamented by granules or radially oriented costae. The costae, located in the center of the valve (Trochus, Bilingua), or close to the margin (Microorbis) are interpreted as reduced or rudimentary linking structures. In some forms the costae bifurcate and coalesce with a spine. However, no structures have yet been noted that could represent attachment points for linking spines, e. g., scrobisculi. The taxa of Group 3 bear pore-like or slit-like structures in central or subcentral positions that are interpreted to represent primitive stages of process formation (punctate-haplo process, scissurate-haplo process). The processes were probably used for chain formation. The slit-like scissurate process that is surrounded by a rim of silica on the outside of the valve may be an early form of the labiate process. This may indicate that the development of true labiate pro- 
cesses, which was completed in the Late Cretaceous, started somewhere within the middle Cretaceous.

The frustules of at least some of the taxa included in Group 3 are very probably heterovalvate. The valves are differentiated by the presence/absence of costae or haplo processes.

Compared to other middle Cretaceous diatoms the taxa of Group 3 are characterized by relatively weakly silicified valves. This may indicate that these taxa could more easily remain in the euphotic zone, compared to the more heavily silicified taxa of Groups 1, 2, 4, and the Kreagra group. Thus the Group 3 taxa were probably also able to dwell successfully in deeper water environments.

Considering the valve symmetry, the structure of the haplo processes, and the location of costae and spines Group 3 can be subdivided into three subgroups.

\section{Subgroup $3 A$}

Subgroup 3A is represented by Microorbis convexus and $M$. undulatus that have a circular valve outline and a distinct central area perforated by one or more punctate-haplo processes (Pl. 2, Figs. 7, 8; Pl. 14, Figs. 3, 5; Pl. 18, Figs. 1, 2). Based on the recovered specimen, we suppose that taxa of Microorbis are heterovalvate. In valves bearing costae and spines, the costae are restricted to the outer $1 / 3$ to $1 / 2$ of the valve face, bifurcate near the valve face margin, and bear a spine at the point of bifurcation.

\section{Subgroup $3 B$}

Subgroup 3B is represented by Trochus elegantulus that has a circular valve outline and one or more radially oriented scissurate-haplo processes clustered in one section of the valve face about midway between the center of the valve face and its margin (Pl. 14, Figs. 1, 2, 4, 7; Pl. 15, Figs. 1, 2, 11). The valve is strongly raised in its central part and ornamented by radial costae that extend only in the center of the valve.

\section{Subgroup 3C}

Subgroup $3 \mathrm{C}$ contains Bilingua rossii that has bipolar valve symmetry. The valve is structured by elevations and the central elevation is ornamented by a costa and a ring of radially oriented slit-like structures on the elevated central area (Pl. 17, Fig. 9; Pl. 18, Fig. 6), which may represent an early stage of labiate processes (scissurate-haplo processes). By its valve outline and the presence of a central cluster of processes $B$. rossii has affinities to diatoms of the suborder Biddulphiineae and especially to those of the families Biddulphiaceae, and thus is probably the oldest taxon that can be assigned to it.

Of these three subgroups, the Subgroups 3B and 3C have most similarities, despite the different valve symmetry. Scissuratehaplo processes occur in both subgroups and valve margin and face are separated by a well developed marginal ridge, the central part of the valve is domed or elevated, and costae and spines are located in the center of the valve. Based on this finding we speculate that Bilingua might derive from taxa represented by Trochus.

The taxa of Group 3 differ distinctly from the taxa of the other two groups. It is not yet clear to us, whether they represent a stage in diatom evolution that by the Albian-Aptian time period was old (more primitive) or modern. As already speculated above, the presence of a more weakly silicified frustule could indicate a more evolved stage because it would enable these taxa to populate open ocean areas. It can also be argued that at least one member of the Group 3 taxa, Bilingua rossii is modern by Albian-Aptian time and represents the ancestor of a diatom branch that has been successful since the Late Cretaceous and the Paleogene.

\section{Group 4}

This group is represented by only one species, Archepyrgus melosiroides. A. melosiroides differs from the other taxa recovered in the studied samples by the structure of the wall, which is areolate and has affinities with that of the modern Melosira granulata group, transferred by Simonsen (1979) to Aulacoseira. Processes were not detected. The linking spines overlap the adjacent valve, interdigitating with the corresponding linking spines, leading to a "close" connection between the individual frustules (Pl. 13, Fig. 1). A similar linking apparatus is developed in taxa of Basilicostephanus leading to an "open" connection between the individual frustules (Pl. 5, Figs. 1, 2). However, because of its valve wall structure Basilicostephanus was included to Group 1 (Subgroup 1A).

Archepyrgus probably evolved in a lineage separate from that of other Lower Cretaceous species described herein.

\section{Kreagra Group}

We did not include the taxa of the genus Kreagra in one of the former groups and we will not place them in a separate group because we know only their well silicified linking apparatus which consists of two or three elongated spines and a central linking notch. The preserved parts of the adjacent valve face are weakly silicified and ornamented by punctate striae. It may be speculated that the Kreagra group is related somehow to the taxa of Subgroup 3A, which have, on the raised central portion of the valve face, radially oriented costae that are interpreted to represent a rudimentary linking apparatus.

\section{SUMMARY}

The study of the extremely well preserved diatom assemblages of late Aptian-early Albian age that were recovered at ODP Site 693 allow new insight into a little known early stage of diatom evolution. We documented 25 taxa in 13 genera, most of them new, which represent a nearshore shallow water diatom assemblage that probably was only very little biased by dissolution or other diagenetic alteration. One prominent characteristic of the encountered diatoms is their ability for chain formation. Instruments for chain formation are a mostly heavily silicified linking apparatus consisting of one or more three-buttressed linking spines and corresponding scrobisculi, or one or more processes located on the valve face in central or subcentral position. Diatoms with a well developed linking apparatus and not possessing a process (e.g., taxa of Group 1, Kreagra-group) are dominant in the studied assemblages. These diatoms were probably at the maximum of their development during the middle Cretaceous time period and they became extinct in the Late Cretaceous (between the Albian and the Campanian). Diatoms that bear one or more processes on the valve face (punctate-haplo process, scissurate-haplo process, perforate process, sipho-shaped process, rhyncho-shaped process) do not possess an apical linking structure, or the apical linking structure is reduced, and in most cases only a rudimentary structure consisting of costae or short spines is developed. A comparison of Albian-Aptian and Campanian-Maestrichtian taxa of the genus Gladiopsis illustrates the total reduction of linking spine structures between the middle and Late Cretaceous. Thus the development of processes supersedes the mostly heavily silicified linking apparats. Taxa of Gladiopsis are prominent in Late Cretaceous diatom assemblages and apparently became extinct just below or around the Cretaceous-Tertiary boundary.

In the middle Cretaceous or not long before, falls the beginning of development from frustules with circular valve plane to frustules with bipolar symmetry. One of the two bipolar taxa encountered in the studied assemblages (Bilingua rossii) has af- 
finities to diatoms of the suborder Biddulphiineae and is probably the oldest known taxon that can be assigned to the family Biddulphiaceae.

The present chapter represents a first step of documentation and discussion of the middle Cretaceous diatom assemblages recovered at Site 693. It will be followed by further publications that will focus on possible generic and phylogenetic interrelationships and that will document more broadly the variability of the diatom species, the composition of the assemblages, and include the descriptions of incompletely documented diatoms, which occur only rarely in the assemblages.

\section{ACKNOWLEDGMENTS}

The authors are very grateful to R. Simonsen for his help and critical remarks. We also thank R. Ross, P. Sims, J. Baldauf, G. Andrews, and A. Abelmann for many suggestions and review of the manuscript. N. I. Strel'nikova contributed remarks at an early stage of the manuscript. We are grateful to $\mathrm{H}$. Harper for making available unpublished information on the Aptian/ Albian in Queensland, Australia. We thank Ruth Cordelair, Ute Bock, and Matt Karrer for laboratory assistance, and H.-G. Gersonde for his advice on the use of Greek and Latin names. This work was supported by the Deutsche Forschungsgemeinschaft and the Byrd Polar Research Center. This is Alfred Wegener Institute contribution No. 218 and Byrd Polar Research Center contribution No. 683.

\section{REFERENCES}

Abelmann, A., Bock, U., Gersonde, R., and Treppke, U., in press. A revised preparation technique for siliceous microfossils.

Anonymous, 1975. Proposals for a standardization of diatom terminology and diagnoses. In Simonsen, R. (Ed.), Third Symp. on Recent and Fossil Marine Diatoms. Kiel. Nova Hedwigia, Beih., 53:323354.

Barker, P. F., Kennett, J. P., et al. 1988. Proc. ODP Init. Repts., 113: College Station, TX (Ocean Drilling Program).

Barron, J. A., 1985. Diatom biostratigraphy of the CESAR 6 Core, Alpha Ridge. In Jackson, H. R., Mudie, P. J., and Blasco, S. M. (Eds.), Initial Geological Report on CESAR: The Canadian Expedition to study the Alpha Ridge, Arctic Ocean, Geol. Surv. Can. Pap. 84-22:137-147.

Barron, E. J., 1987. Cretaceous plate tectonic reconstructions. Palaeogeogr., Palaeoclimatol., Palaeoecol., 59:3-29.

Benda, L., 1982. Die Diatomeen des späten Apt in Nordwestdeutschland. Geol. Jahrb., A65:405-411.

Bergstresser, T. J., and Krebs, W. N., 1983. Late Cretaceous (Campanian-Maastrichtian) diatoms from the Pierre Shale, Wyoming, Colorado and Kansas. J. Paleontol. 57:883-891.

Dun, W. S., Rands, W. H., and David, B. A., 1901. Note on the occurrence of diatoms, radiolaria, and infusoria in the Rolling Downs Formation (Lower Cretaceous), Queensland. Proc. Linn. Soc., N. S. W., 26:299-309.

Forti, A., 1933. Contribuzioni diatomologiche XIV-Schulziella nov. nom. Dallas Hanna et Forti (1933). Atti R. 1st. Veneto Sci. Lett. Arti, 2;92:1279-1283.

Forti, A., and Schulz, P., 1932. Erste Mitteilung über Diatomeen aus dem Hannoverschen Gault. Beih. Bot. Zentralbl., 50(2):241-246.

Foucault, A., Servant-Vildary, S., Fang, N., and Powichrowski, L., 1986. Un des plus anciens gisements de diatomées découvert dans l'Albien-Cénomanien inférieur des Alpes ligures (Italie). Remarque sur l'apparition de ces algues. C.R. Acad. Sci., T. 303, Ser. 2, 5:397402.

Georgi, K.-H.,1976. Mikrofaunistische-lithologische Untersuchungen der Hilssandstein-Region (Apt/Alb) im Raum Salzgitter-Goslar. Mitt. Geol. Inst. Tech. Univ., Hannover, 13:5-112.

Geroch, S., 1978. Lower Cretaceous diatoms in the Polish Carpathians. Rocz. Pol. Tow. Geol., 48:283-295.

Glezer, Z. I., Makarova, I. V., Moisseeva, A. I., and Nikolaev, V. A., 1988. The diatoms of the USSR. Fossil and recent. Vol 2. Fasc. 1, Pyxidiculaceae, Thalassiosiropsidaceae, Triceratiaceae, Thalassiosiracea. Leningrad "Nauka" Leningrad Branch (in Russian).
Haig, D. W., and Barnbaum, D., 1978. Early Cretaceous microfossils from the type Wallumbilla Formation, Surat Basin, Queensland. Alcheringa, 2:159-178.

Hajós, M., and Stradner, H., 1975. Late Cretaceous Archaemonadaceae, Diatomaceae, and Silicoflagellatae from the South Pacific Ocean, Deep Sea Drilling Project, Leg 29, Site 275. In Kennett, J. P., Houtz, R. E., et al., Init. Repts. DSDP, 29: Washington (U.S. Govt. Printing Office), 913-1009.

Hanna, G. D., 1927. Cretaceous diatoms from California. Occas. Pap. Calif. Acad. Sci., 13:5-49.

1934. Additional notes on diatoms from the Cretaceous of California. J. Paleontol. 8:352-355.

Harper, H. E., 1977. A Lower Cretaceous (Aptian) diatom flora from Australia. Nova Hedwigia, Beih., 54:411.

Harwood, D. M., 1988. Upper Cretaceous and lower Paleocene diatom and silicoflagellate biostratigraphy of Seymour Island, eastern Antarctic Peninsula. In Feldman, R. and Woodburne, M. O. (Eds.), Geology and Paleontology of Seymour Island. Geol. Soc. Am. Mem. Ser. 169:55-129.

Hasle, G. R., and Syvertsen, E. E., 1985. Thalassiosiropsis, a new diatom genus from the fossil record. Micropaleontology, 31:82-91.

Herth, W., and Zungenmaier, P., 1977. Ultrastructure of the chitine fibrils of the centric diatom Cyclotella cryptica. J. Ultrastruct. Res., $61: 230-239$.

Herth, W., and Barthlott, W., 1979. The site of b-chitine fibril formation in centric diatoms. 1. Pores and fibril formation. J. Ultrastruct. Res., 68:6-15.

Jousé, A. P., 1949. New upper Cretaceous diatoms and silicoflagellates from argillaceous sands along the Bol'shoi Kitoi River, east slope of the Northern Ural. Botan. Mater. Otd. Spor. Rast. Bot. Inst. Akad. Nauk SSSR, 6:1-6 (in Russian).

Kemper, E., Bertram, H., and Deiters, H., 1975. Zur Biostratigraphie und Palökologie der Schichtenfolge Ober-Apt/Unter-Alb im Beckenzentrum nördlich und östlich von Hannover. Ber. Naturhist. Ges., Hannover, 119:49-85.

Kitchell, J. A., and Clark, D. L., 1982. Late Cretaceous-Paleogene paleogeography and paleocirculation: evidence of north Polar upwelling. Palaeogeogr., Palaeoclimatol., Palaeoecol. 40:135-165.

Long, J. A., Fuge, D. P., and Smith, J., 1946. Diatoms of the Moreno Shale. J. Paleontol. 20:89-118.

Müller, O., 1912. Diatomeen aus den Turonschichten der Kreide. Ber. Deutsch. Bot. Ges., 29:661-668.

Nikolaev, V. A., and Strel'nikova, N. I., 1987: New data on the structure and systematic position of some species of the genus Coscinodiscus (Bacillariophyta). Bot. Zh. SSSR, 72:245-247. (in Russian).

Rad, U. von, Riech, V., and Rosch, H., 1977. Silica diagenesis in continental margin sediments off Northwest Africa. In Lancelot, Y., Seibold, E., et al., Init. Repts., DSDP, 41: Washington (U.S. Govt. Printing Office), 879-905.

Ross, R., and Sims, P. A., 1972. The fine structure of the frustule in centric diatoms: a suggested terminology. Br. Phycol. J., 7:139-163. 1987. Further genera of the Biddulphiaceae (diatoms) with interlocking linking spines. Bull. Br. Mus. Nat. Hist. (Bot.), 16(4): 269-311.

Ross, R., Cox, E. J., Karayeva, N. J., Mann, D. G., Paddock, T.B.B., Simonsen, R., and Sims, P. A., 1979. An amended terminology for the siliceous components of the diatom cell. Nova Hedwigia Beih., 64:513-533.

Rothpletz, A., 1896. Über die Flysch-Fucoiden und einige andere fossile Algen, sowie über liasische, Diatomeen führende Hornschwämme. Z. Deutsch. Geol. Ges. 48:854-914.

Rüst, G., 1885. Beiträge zur Kenntniss der fossilen Radiolarien aus Gesteinen des Jura. Palaeontographica, 31 (3/7): 271-321.

Schulz, P., 1935. Diatomeen aus senonen Schwammgesteinen der Danziger Bucht. Zugleich ein Beitrag zur Entwicklungsgeschichte der Diatomeen. Bot. Archiv, 37:383-413.

Shipboard Scientific Party, 1988. Site 693. In Barker, P. F., Kennett, J. P., et al., Proc. ODP, Init. Repts., 113: College Station, TX (Ocean Drilling Program), 329-448.

Simonsen, R., 1972. Ideas for a more natural system of the centric diatoms. Nova Hedwigia., Beih. 39:37-54. 9-71.

Strel'nikova, N. I., 1964. New species of diatom algae from the Upper Cretaceous deposits of the Syny River Basin (West Siberia). Paleo- 
phytol. sbornok, "Nedra", Trudy Vsesoyuznogo neft, nauchnois, geol-razved. inst. (VNIGRI) 239:229-323 (in Russian).

, 1965. De diatomeis Cretae superioris raris et novos declivis orientalis montium Uralensium Polarium. Nov. syst. niz. rast., Bot. Inst. V.A. Komarova, Akad. Nauk SSSR:29-38 (in Russian).

, 1966. Revisio specierum generum Gladius Schulz et Pyxilla Grev. (Bacillariophyta) e sedimentis Cretae superioris. Nov. syst. niz. rast. Bot. Inst. V. A. Komarova, Akad. Nauk SSSR:23-36 (in Russian).

, 1968. Late Cretaceous diatom algae. Iskop. Diat. Vodor. SSSR, Sibirskoe Otd. Inst. Geol. Geof., Akad. Nauk SSSR: 17-21 (in Russian).

1971. Species novae bacillariophytorum e sedimentis Cretae posterioris in declivitate orientali partis polaris ac praepolaris montium Uralensium. Nov. Syst. Plat. non Vasc. 8:41-52 (in Russian). , 1974. Late Cretaceous diatoms from western Siberia: Acad. Nauk SSSR, Moscow (in Russian).
1975. Diatoms from the Cretaceous period. In Simonsen, R. (Ed.), Third Symp. Recent and Fossil Diatoms, Kiel. Nova Hedwigia, Beih., 53:311-321.

Strel'nikova, N. I., and Martirosjan, G. N., 1981. Lower Cretaceous diatom algae from Stavropol. Viestnik LGU, Ser. biologiya. 3:52-57 (in Russian).

Tectonic Map of the Scotia Arc, 1985. 1:3,000,000 BAS (Misc.) 3, Cambridge, British Antarctic Survey.

Wall, J. H., 1975. Diatoms and radiolarians from the Cretaceous system of Alberta-a preliminary report. Geol. Assoc. Can. Spec. Pap., 13: 391-409.

Date of initial receipt: 20 March 1989

Date of acceptance: 14 September 1989

Ms 113B-127 

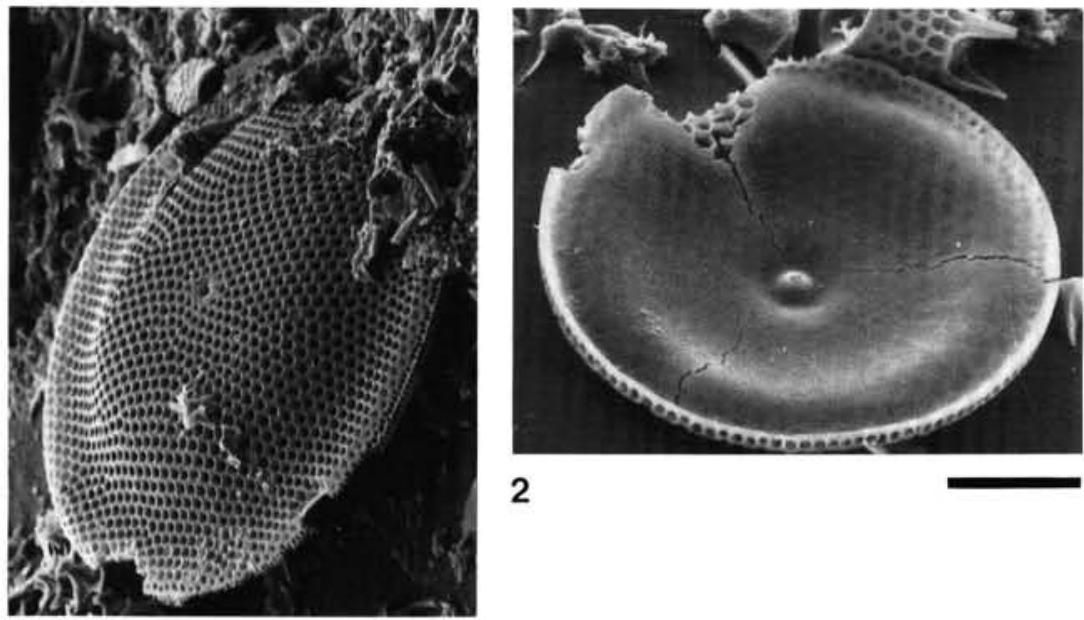

2

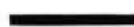

1

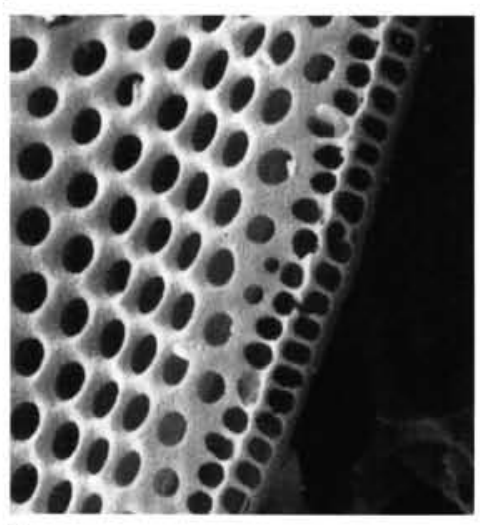

4

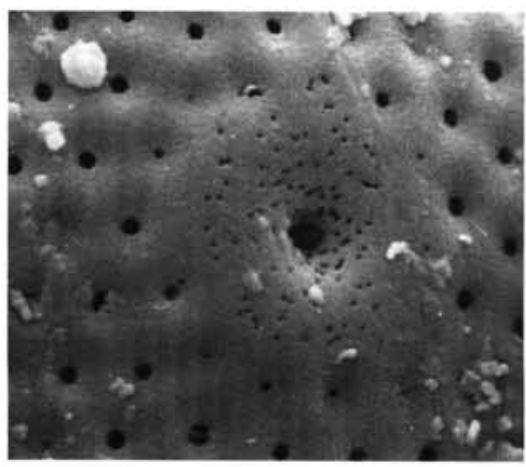

7

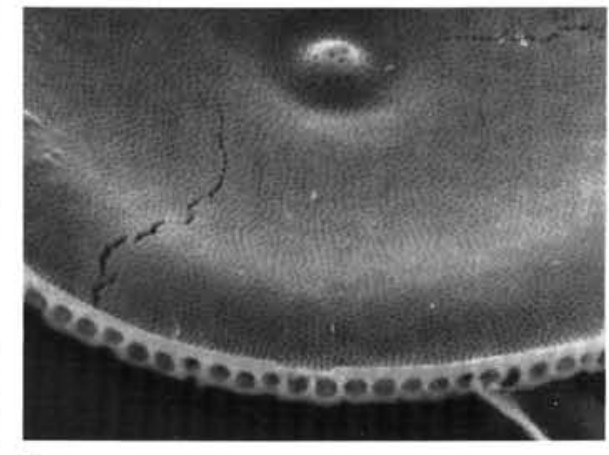

5

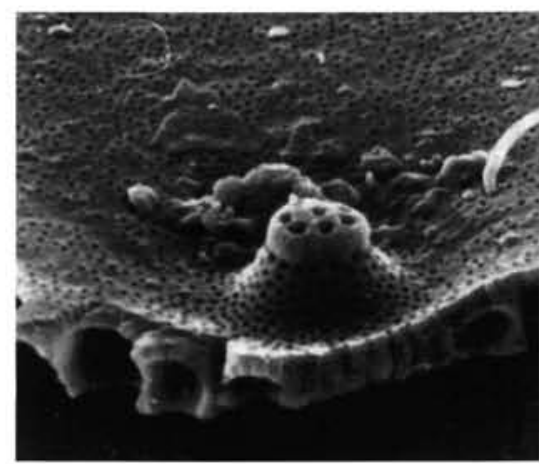

8

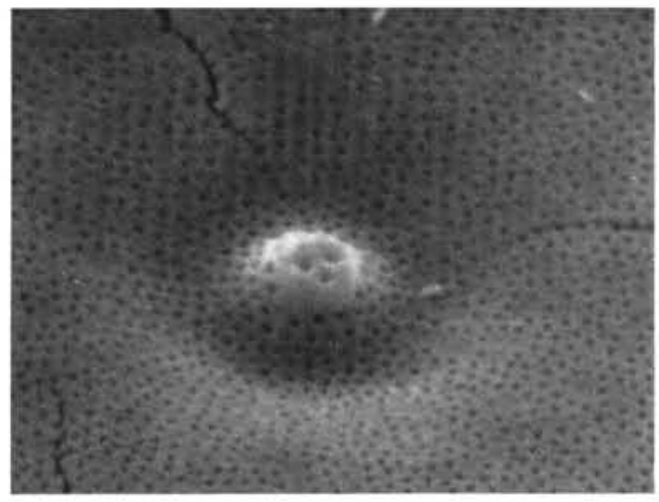

3
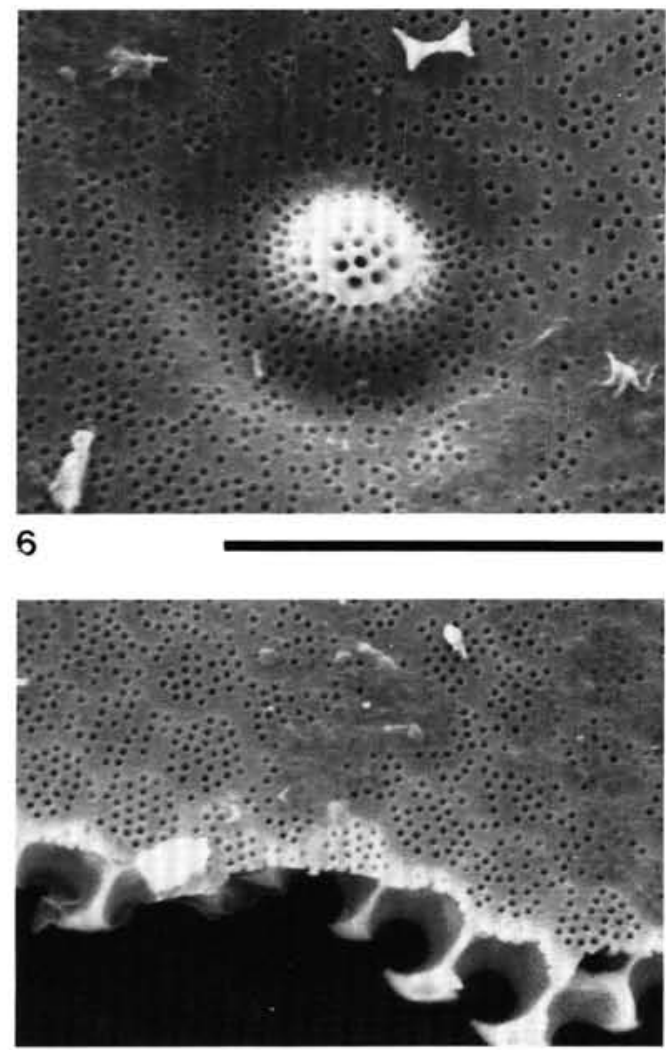

9

Plate 1. (Scale bar $=10 \mu \mathrm{m}$ unless stated otherwise) 1-9. SEM of Praethalassiosiropsis hasleae sp. nov., (1) external view of valve (bar $=100 \mu \mathrm{m}$ ); (2) internal view of valve with central perforate process and velum pores; $(3,6,8)$ internal view of perforate process; $(4,5)$ valve margin, external and internal view; (7) external view of central perforate process; (9) internal view of loculate areolae with external foramina and internal vela. (1-6, 9) from Sample 113-693B-19X-4, 77-78 cm; (7) from Sample 113-693A-44R-1, 14-18 cm; (8) from Section 113-693B-19X-4, CC. 


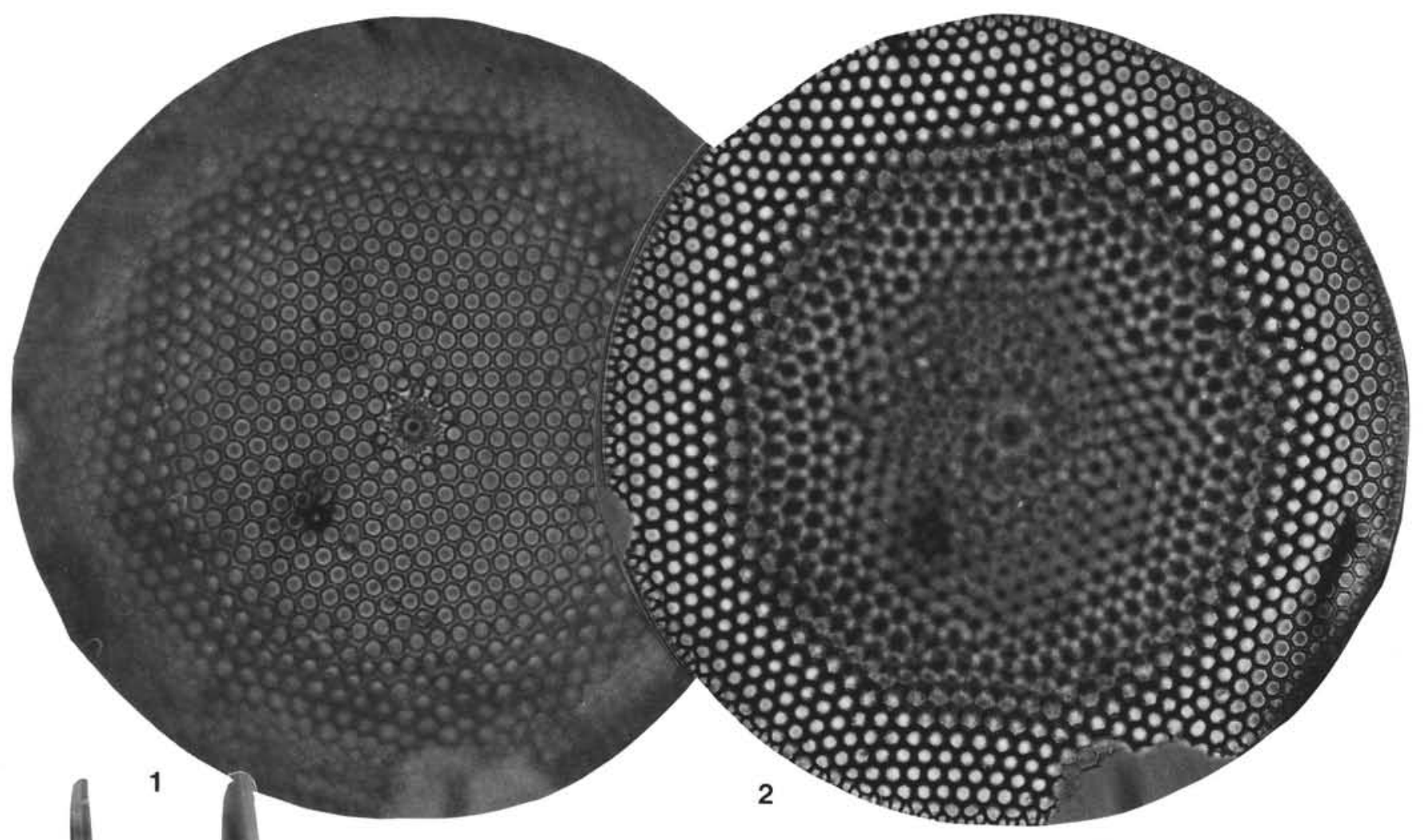

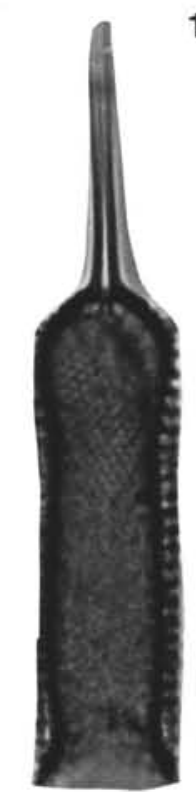

3

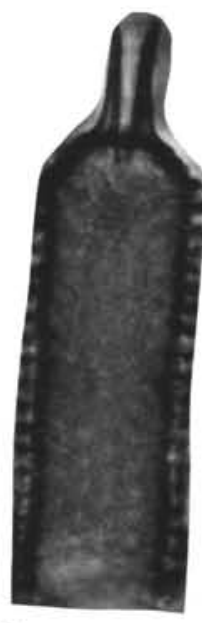

5

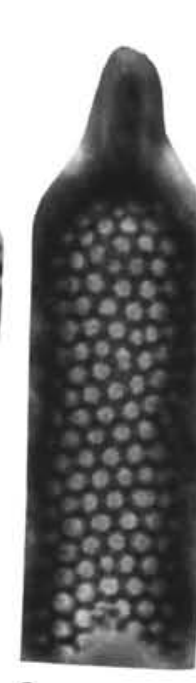

6

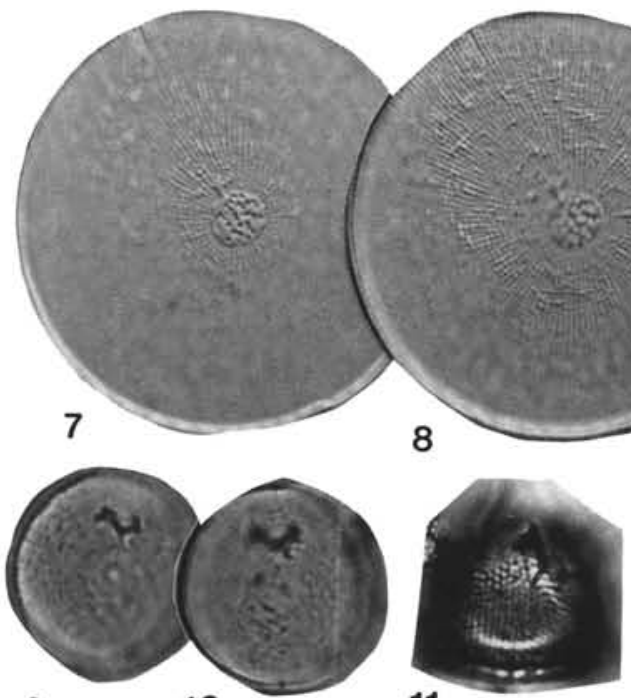

11
9
10

Plate 2. (All specimens from Sample 113-693B-19X-4, 77-78 cm, and $\times 1500$ unless stated otherwise) 1, 2. Praethalassiosiropsis hasleae sp. nov., $\times 960$, holotype. 3-6. Rhynchopyxis siphonoides sp. nov., valve mantle view, note apical rhyncho-shaped process with external tube-like prolongation and inside projection, $(3,4)$ holotype. 7, 8. Microorbis convexus sp. nov., Sample 113-693B-19X-4, 103-104 cm, holotype. 9, 10. Microorbis undulatus sp. nov., holotype. 11, 12. Basilicostephanus mirabilis sp. nov., oblique view. 


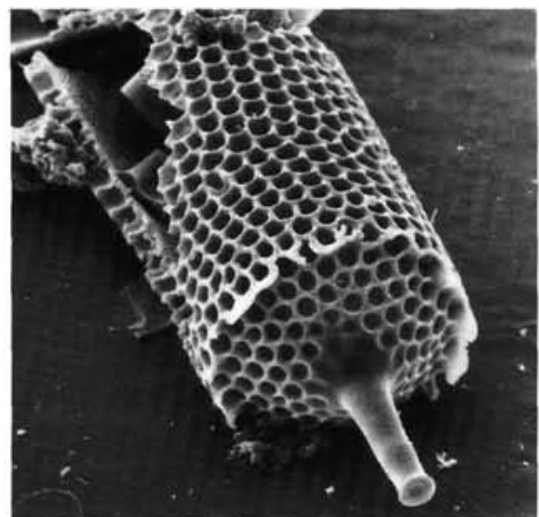

1

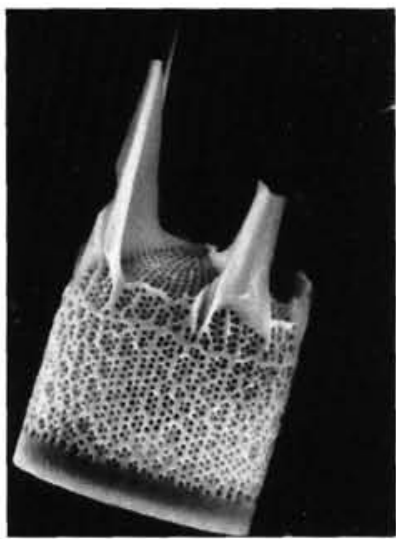

4

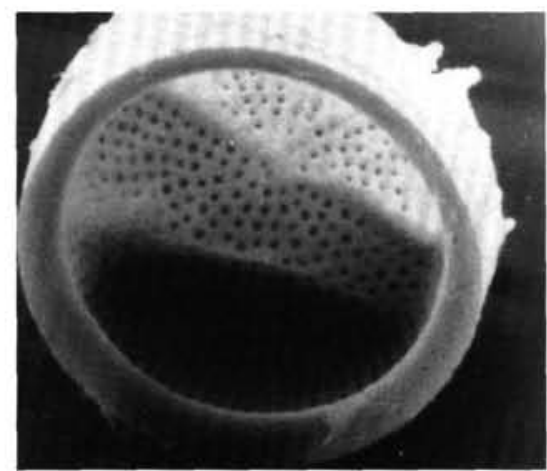

7

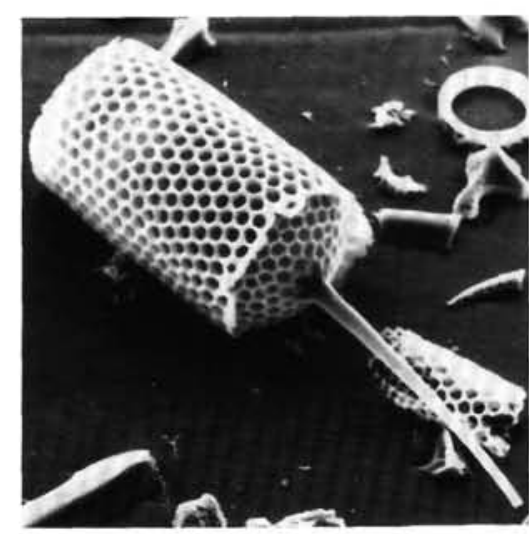

2

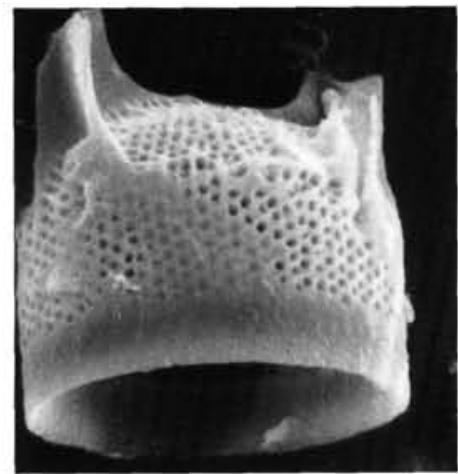

5

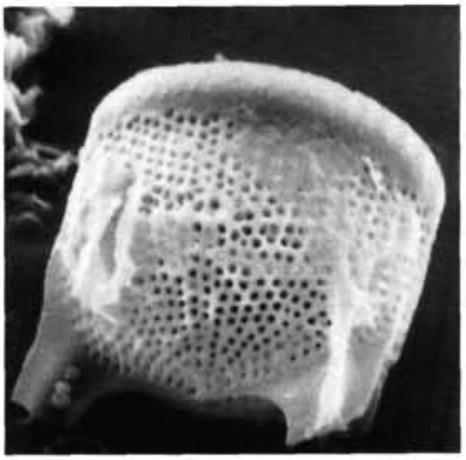

8

6

9

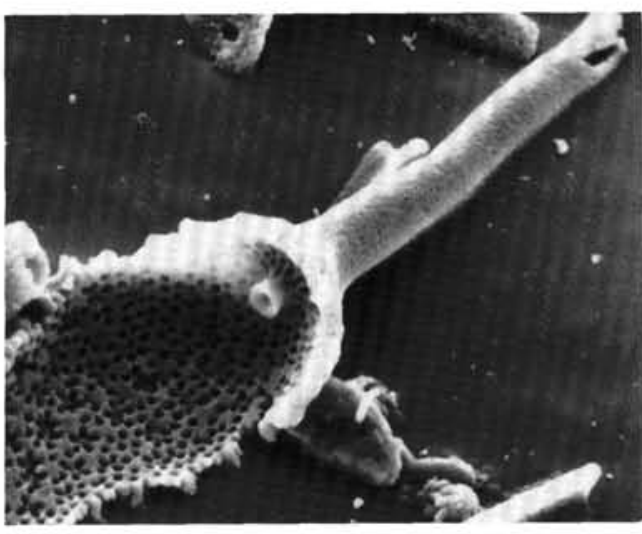

3
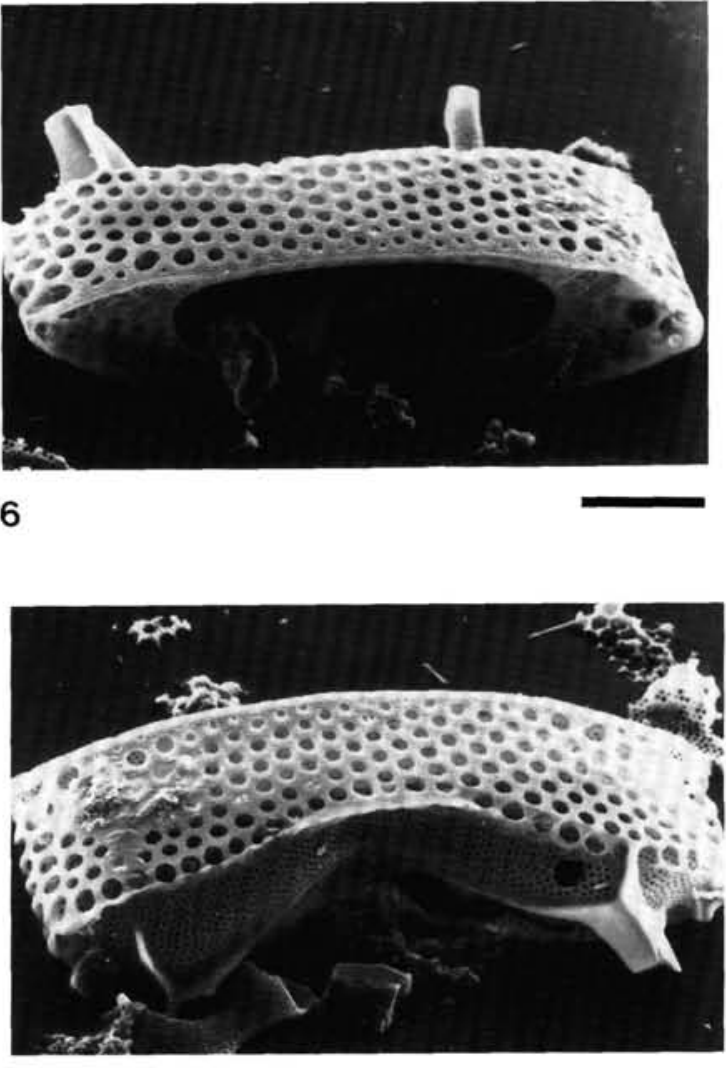

Plate 3. (All specimens from Sample 113-693B-19X-4, 77-78 cm; scale bar $=10 \mu \mathrm{m}$ ) 1-2. Rhynchopyxis siphonoides sp. nov., SEM external view with central rhyncho-shaped process. 3. $R$. siphonoides sp. nov., internal view of partly corroded valve with rhyncho-shaped process. 4. Basilicostephanus ornatus sp. nov., external view of valve mantle and valve margin with "Ringleiste", pseudoloculi not well developed. 5, 7, 8. Basilicostephanus mirabilis sp. nov., (5) external view of valve mantle; (7) internal view of valve face; (8) external view of valve face, linking spines broken. 6 , 9. Kerkis bispinosa sp. nov., (6) external view with septal plate; (9) external view of valve face and valve mantle, note triangular scrobisculi at valve poles. 

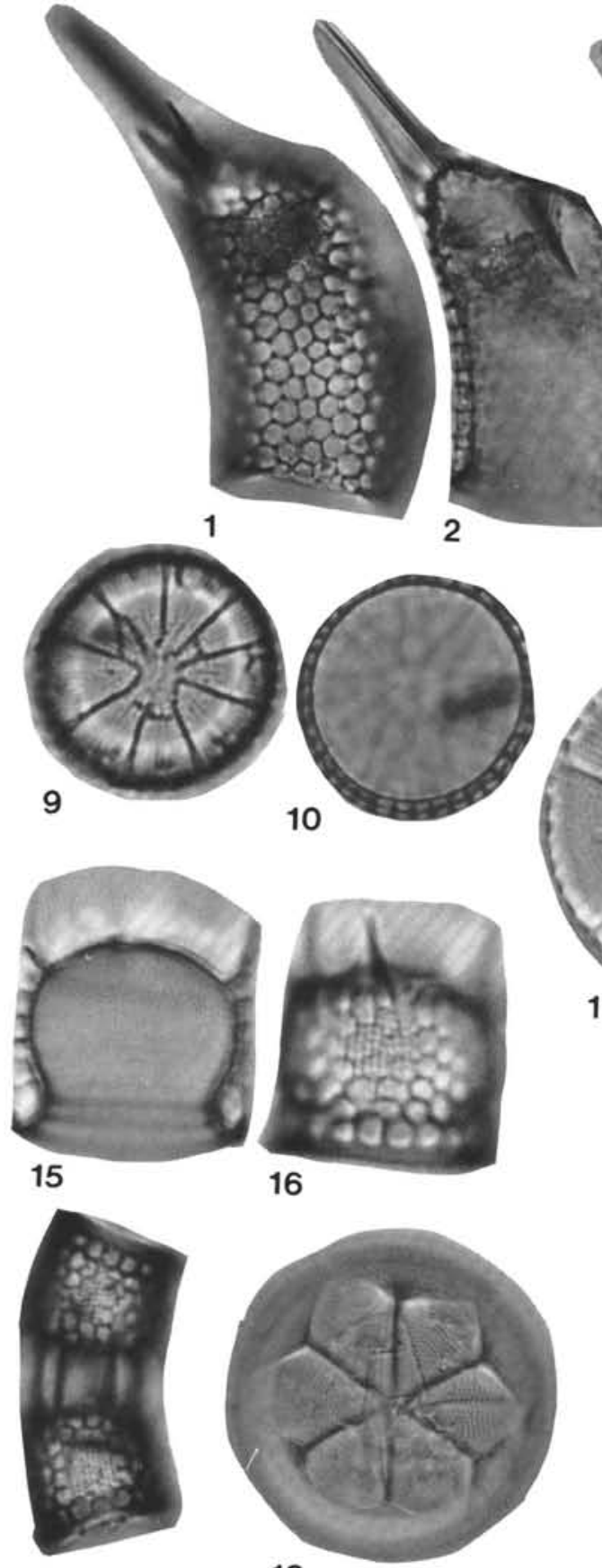

17

15

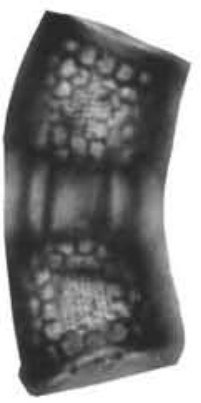

16

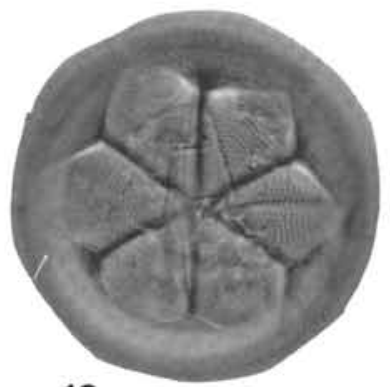

18

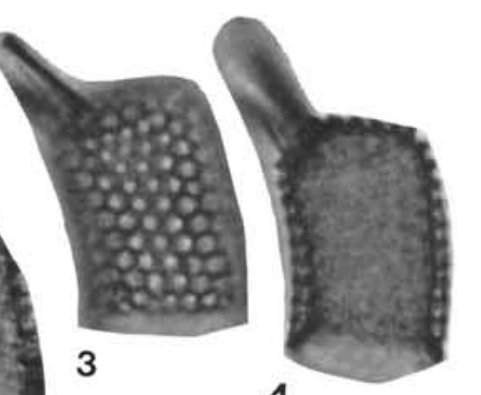

4

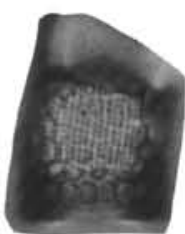

5

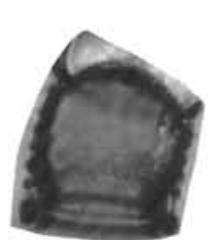

6

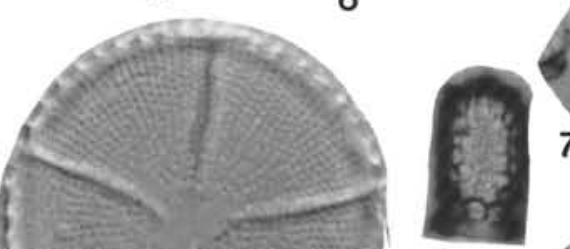

11

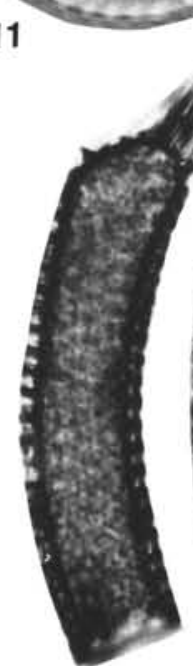

19
12
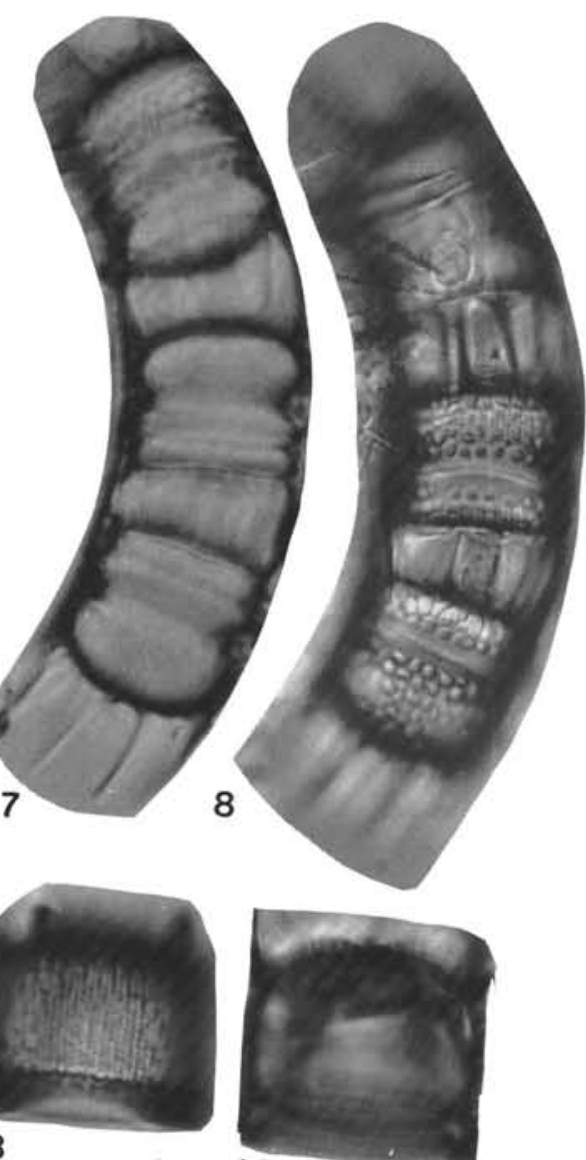

14

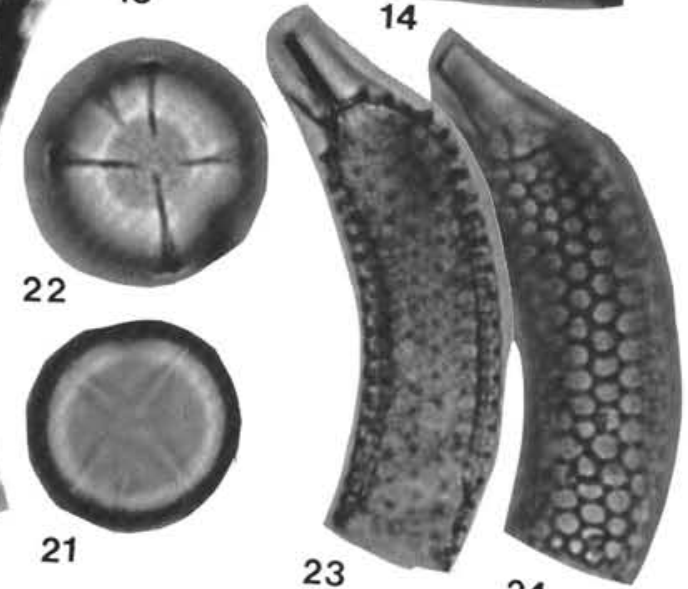

24

Plate 4. 1-4. Ancylopyrgus reticulatus sp. nov., Sample 113-693B-19X-4, 77-78 cm, $\times 1500,(3,4)$ valve mantle view. 5-12, 15-17. Basilicostephanus ornatus sp. nov., $(5,6)$ valve mantle view, Sample 113-693B-19X-4, 103-104 cm, $\times 1500 ;(7,8)$ in chain formation, Sample 113-693B-19X-4, 77-78 cm, $\times 1000$; (9-11) valve face, Sample 113-693B-19X-4, 77-78 cm, $\times 2000$; (12) valve mantle view, Sample 113-693B-19X-4, 103-104 cm, $\times 1500$; $(15,16)$ holotype, Sample 113-693B-19X-4, 77-78 cm, $\times 2000$; (17) valve mantle view, chain formation. Paratype Sample 113-693B-19X-4, 103-104 cm, $\times 1500.13,14,21,22$. Basilicostephanus mirabilis sp. nov., $(13,14)$ valve mantle view, Sample $113-693 \mathrm{~B}-19 \mathrm{X}-4,77-78 \mathrm{~cm}, \times 1500$, $(21,22)$ valve face, Sample 113-693B-19X-4, 77-78 cm, $\times 1500$. 18. Gladius perfectus sp. nov., valve face with linking apparatus, Sample 113-693B$19 \mathrm{X}-4,77-78 \mathrm{~cm}, \times 1000$. 19, 20, 23, 24. Ancylopyrgus reticulatus var. elongatus var. nov., Sample $113-693 \mathrm{~B}-19 \mathrm{X}-4,77-78 \mathrm{~cm}, \times 1500,(19,20)$ holotype, valve mantle view at different focus, $(23,24)$ valve mantle view at different focus. 

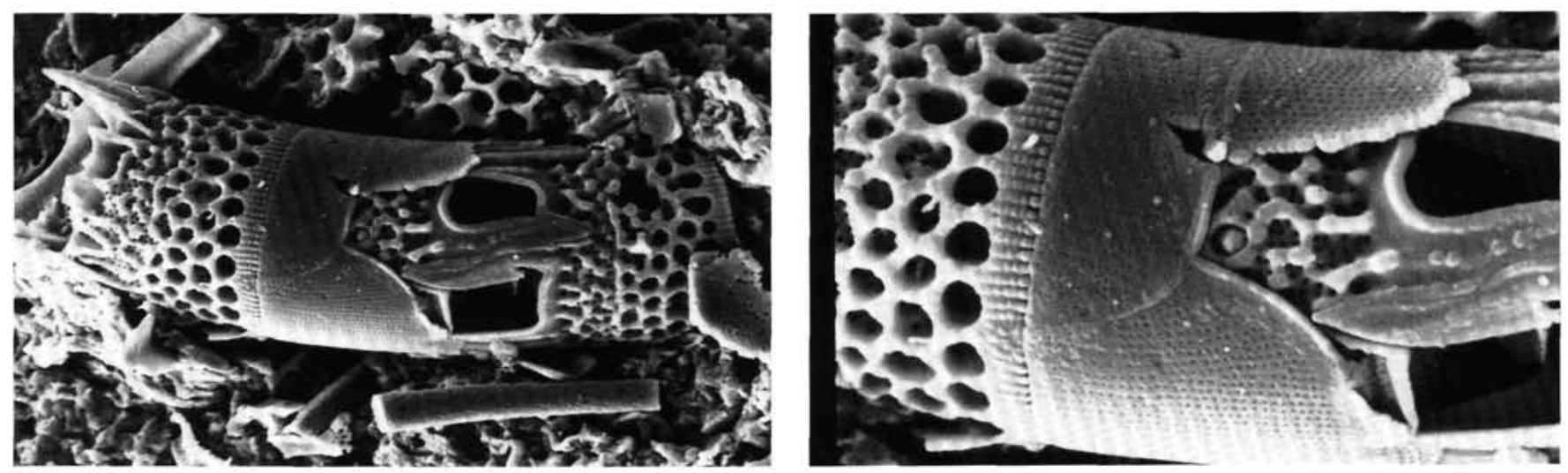

1
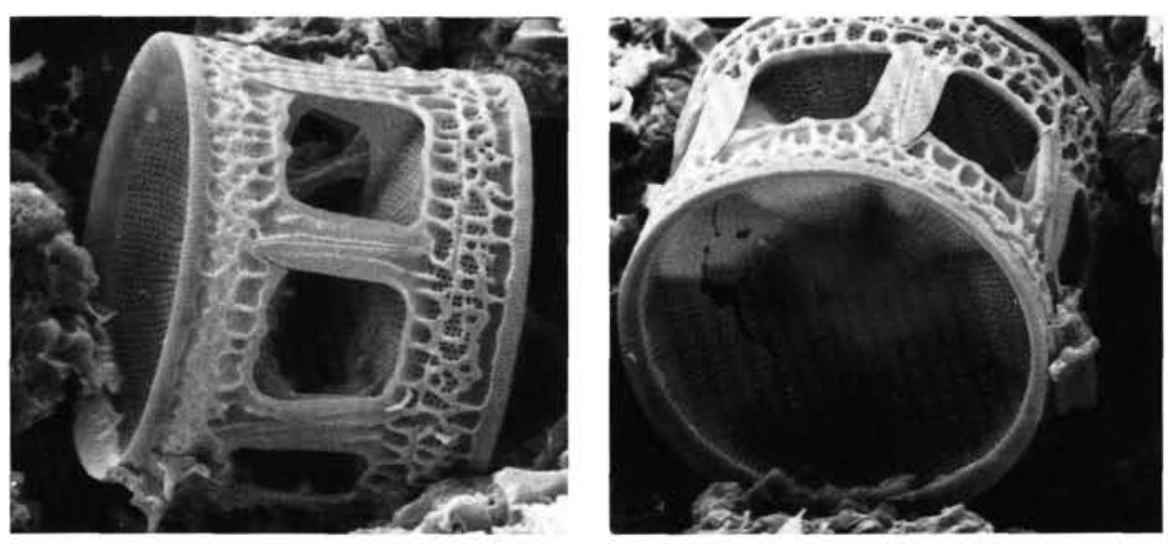

3

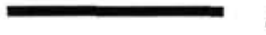

4
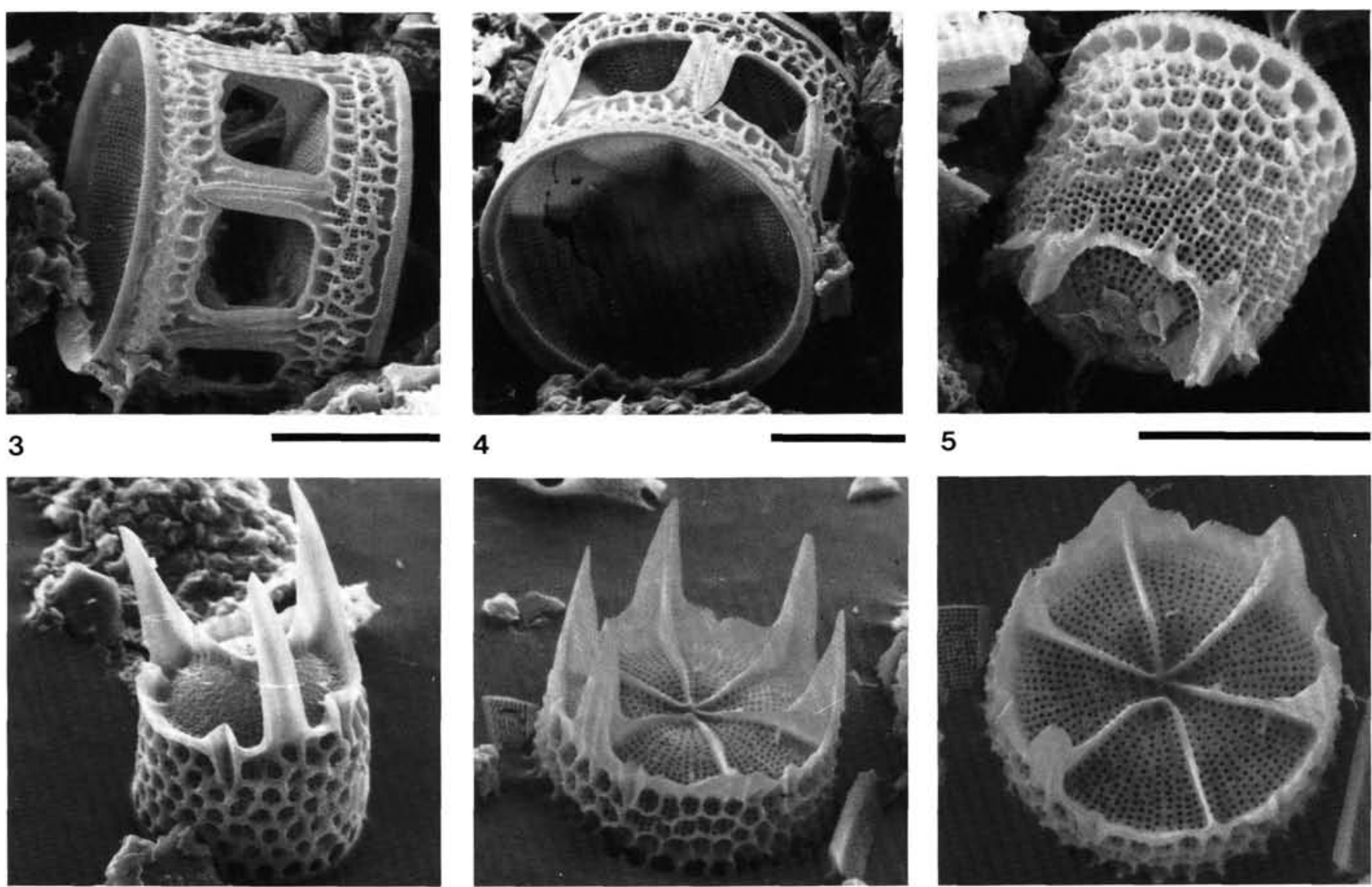

6
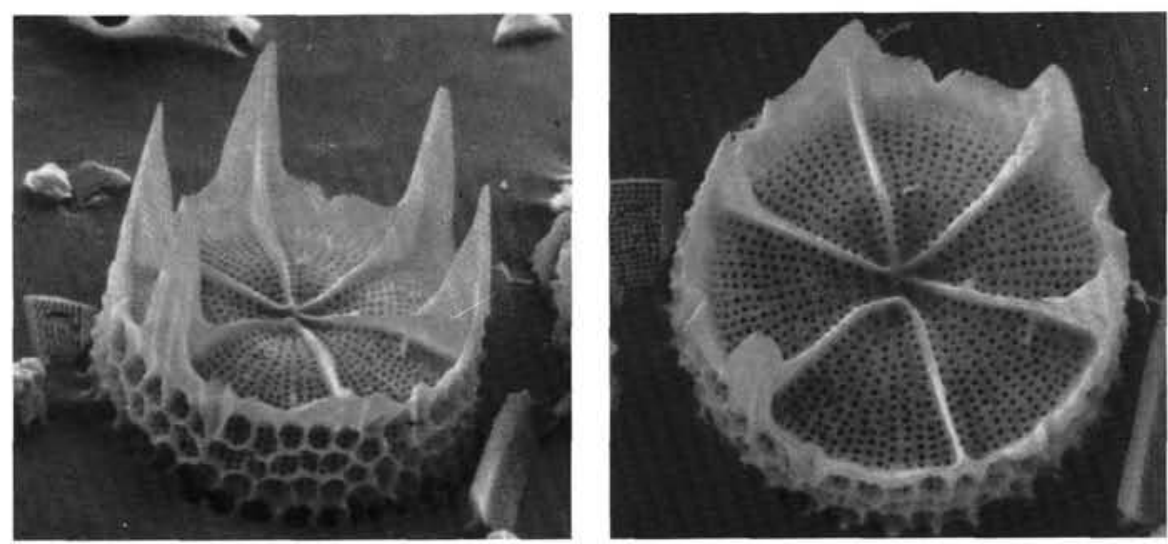

7

8

Plate 5. (All specimens from Sample 113-693B-19X-4, 77-78 cm, unless stated otherwise; scale bar $=10 \mu \mathrm{m}$ ) 1-8. Basilicostephanus ornatus sp. nov., SEM, $(1,2)$ chain with girdle band, Sample 113-693B-19X-4, 103-104 cm; (3) valves with low valve margin connected by linking apparatus; (4) internal view of valve face; $(5)$ external view of valve mantle, structure of marginal sulcus well visible; $(6,7)$ individual valves with well preserbed linking app ratus, note structure of three-buttressed linking spines and scrobisculi at valve face margin; (8) external view of valve face with radial costae, same specimen as illustrated in (7). 


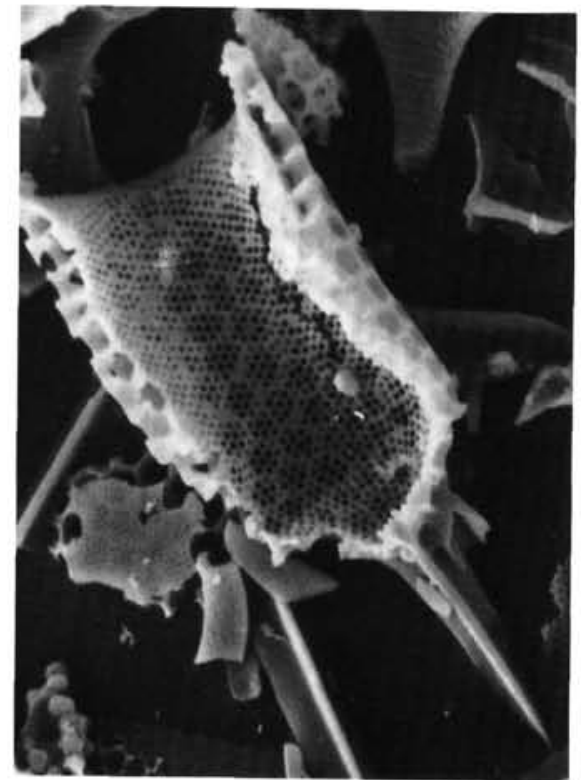

1

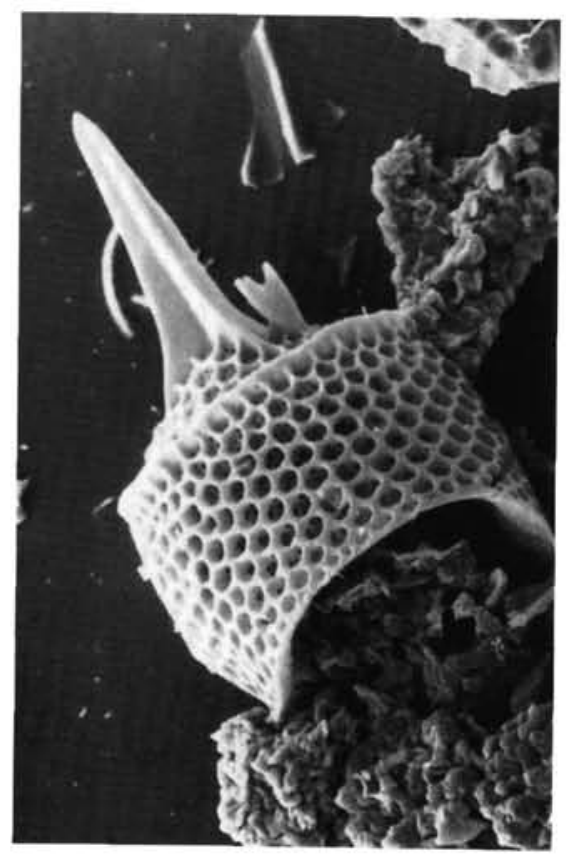

5
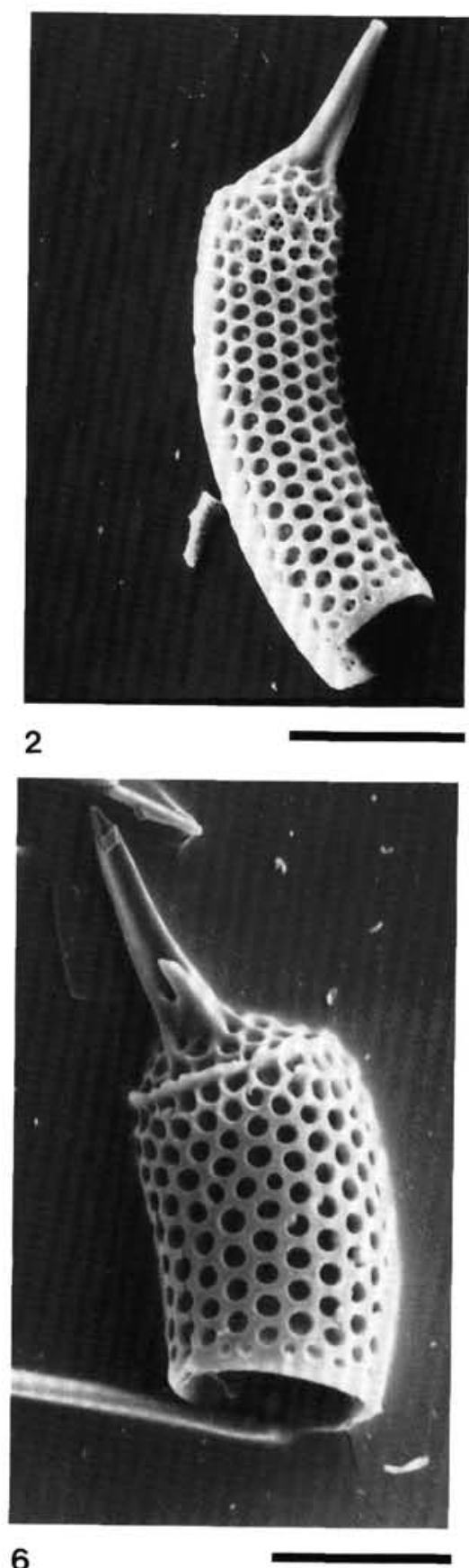

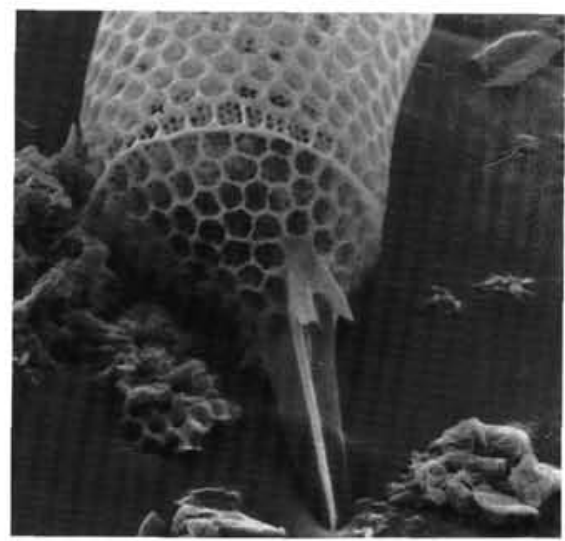

3

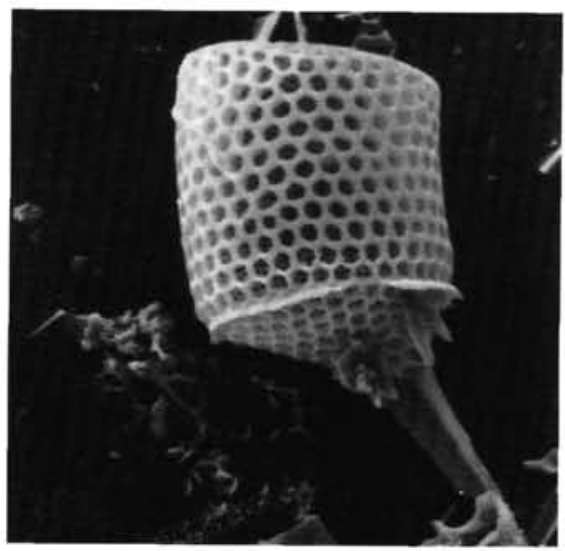

4

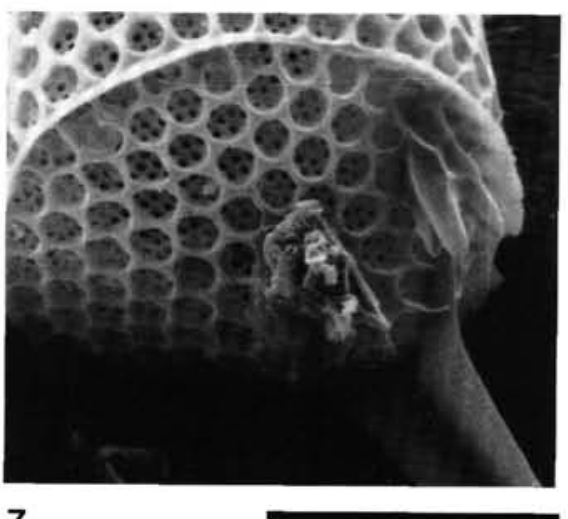

7

Plate 6. (All specimens from Sample 113-693B-19X-4, 77-78 cm, unless stated otherwise; scale bar $=10 \mu \mathrm{m}$ ) 1, 3-7. Ancylopyrgus reticulatus sp. nov., SEM, (1) internal view of valve margin, Section 113-693A-44R, CC; (3-7) external view of valve margin and valve face with linking spine and scrobiculus of linking structure, note "tulip-flower" structure of scrobisculi; (6) external view, scrobiculus coalescing with linking spine, Section 113-693A-44R, CC. 2. Ancylopyrgus reticulatus var. elongatus var. nov., SEM external view. 


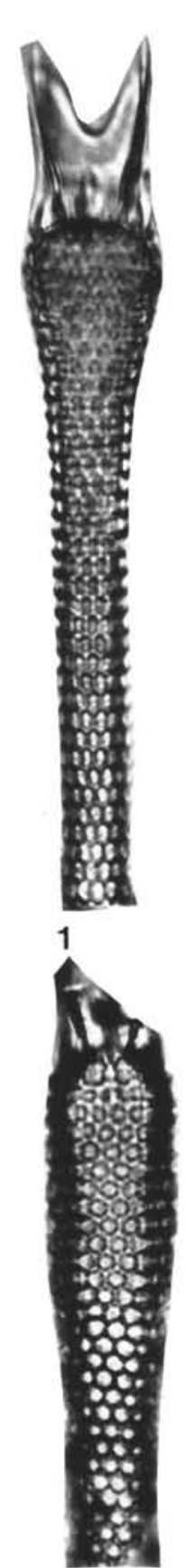

9

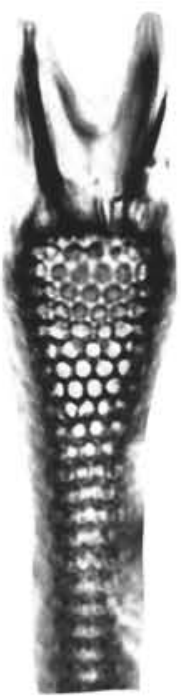

2

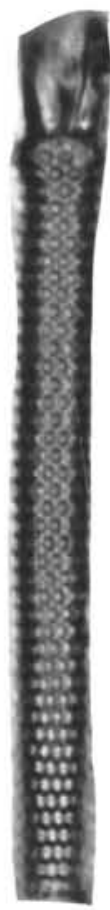

10

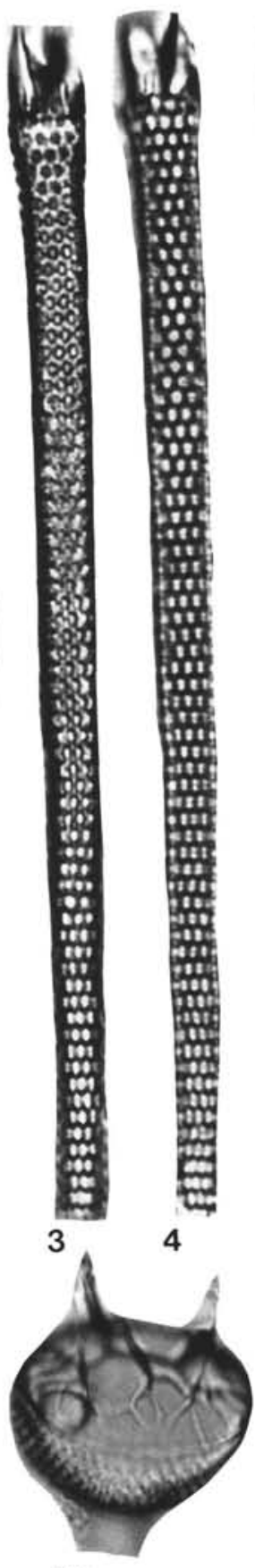

12

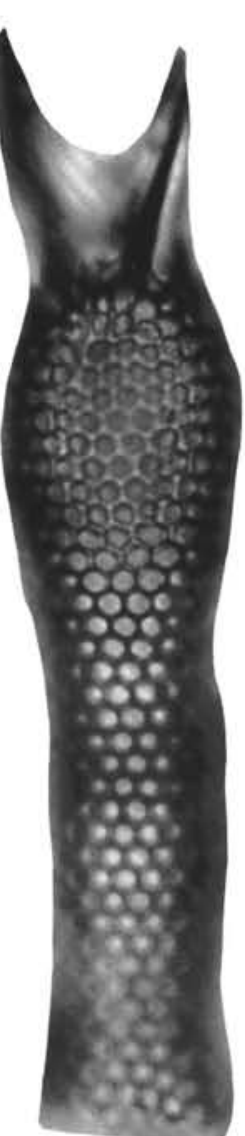

5
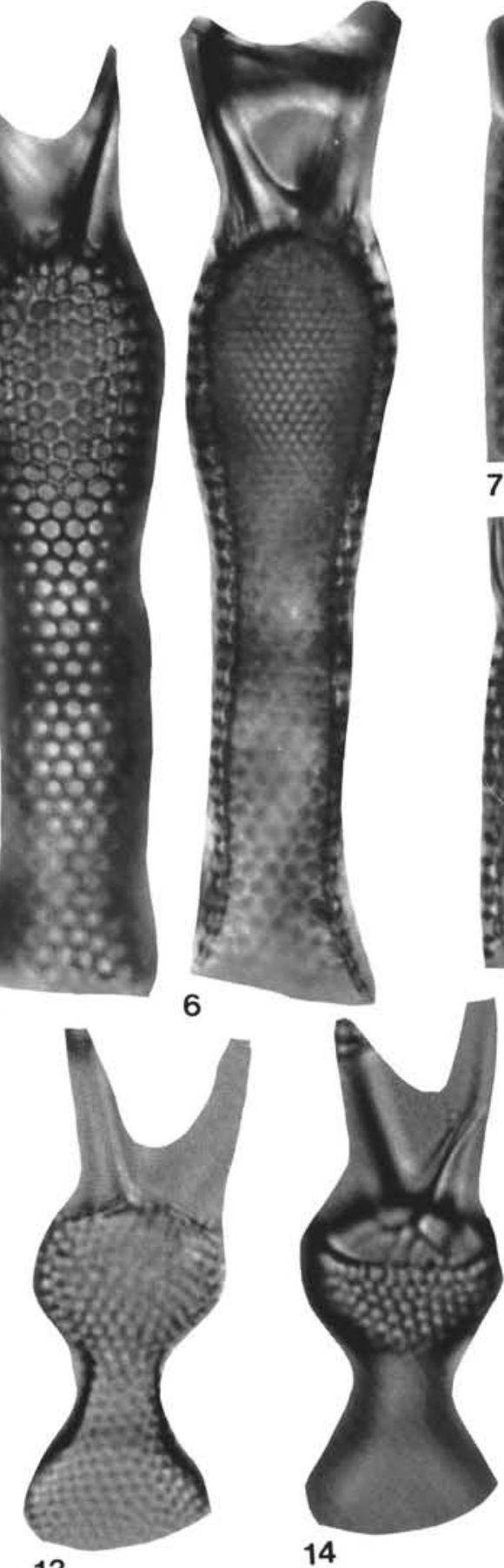

13

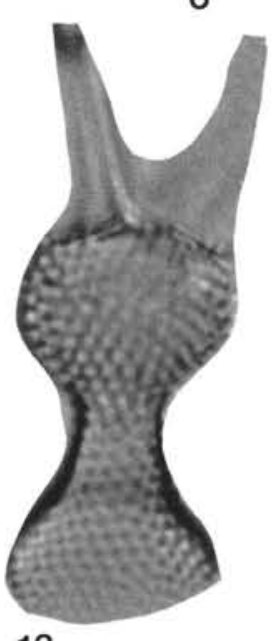

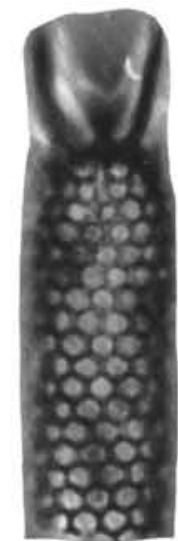

7

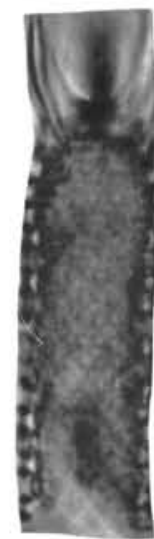

8

Plate 7. (All specimens from Sample 113-693B-19X-4, 77-78 cm; $\times 1500$ unless stated otherwise) 1, 2. Gladius antiquus Forti and Schulz, neotype, valve mantle view at different focus. $\mathbf{3 , 4 , 1 0 , 1 1}$, and $\mathbf{1 5}$. Gladius antiquus var. tenuis var. nov., valve mantle view, (3, 4) holotype. 5, 6. Gladius trispinosus sp. nov., valve mantle view at different focus. $\mathbf{7 , 8}$. Gladius trispinosus var. tenuis var. nov., girdle view at different focus. 9 . Gladius antiquus var. nodosus var. nov., holotype, valve mantle view. 12-14. Gladius rhizophorus sp. nov., $\times 1000$, (12) oblique view with valve face; (13, 14) holotype, valve mantle view at different focus. 

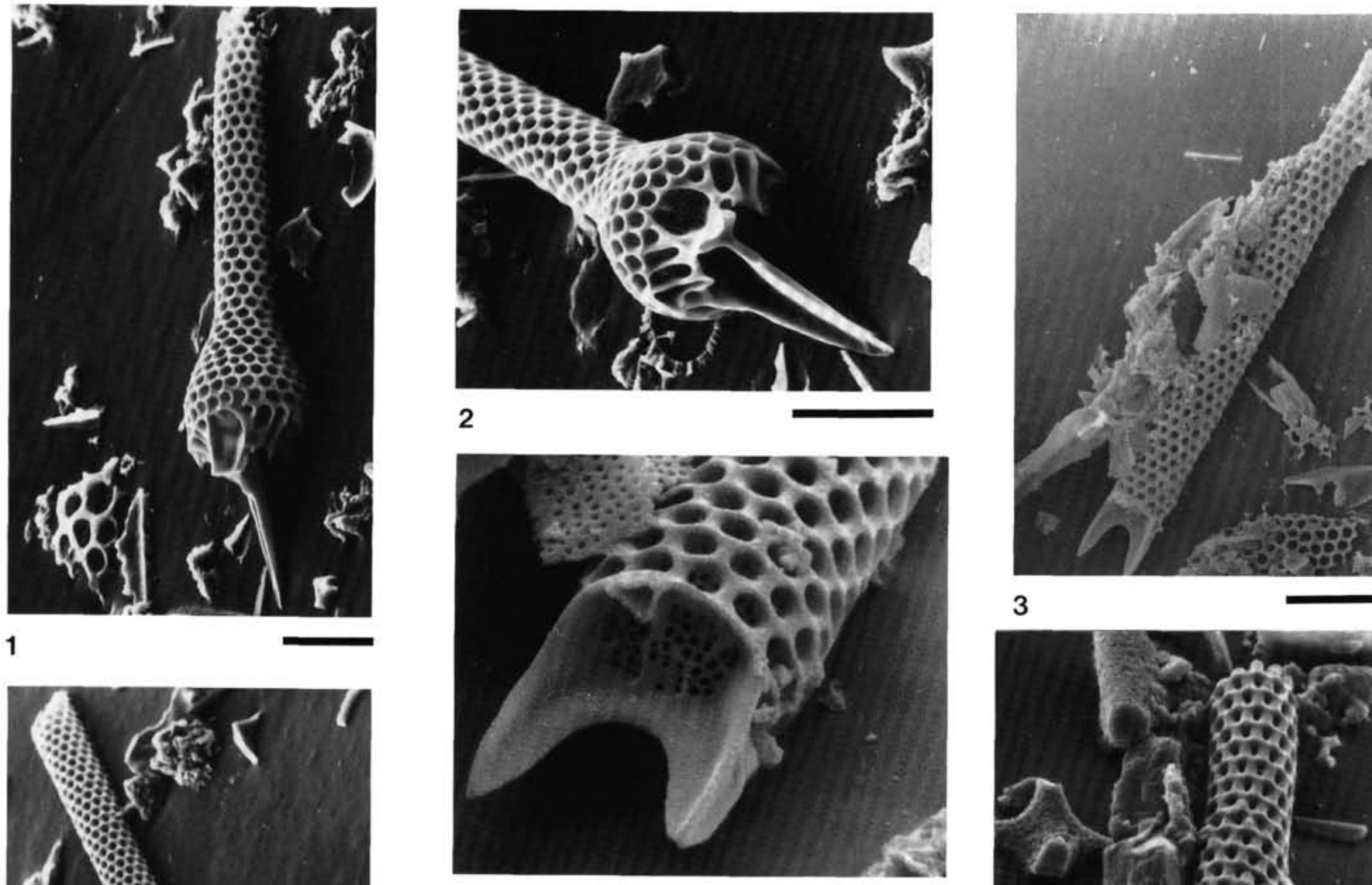

3

1

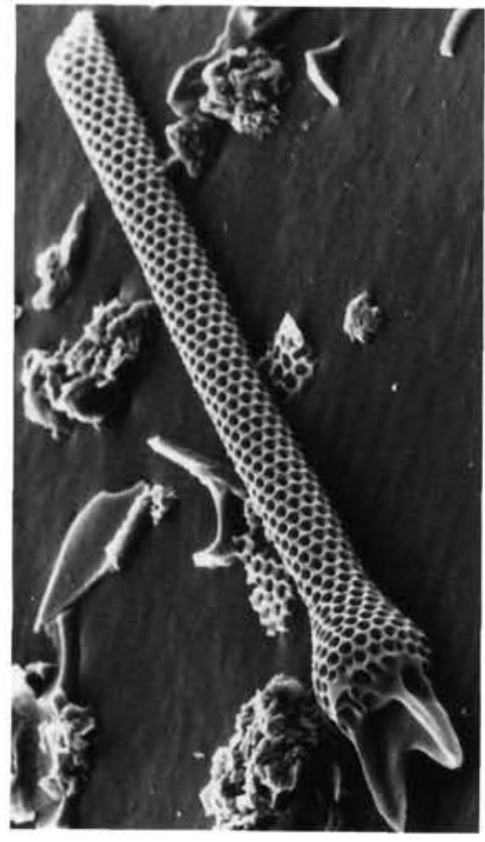

5

4

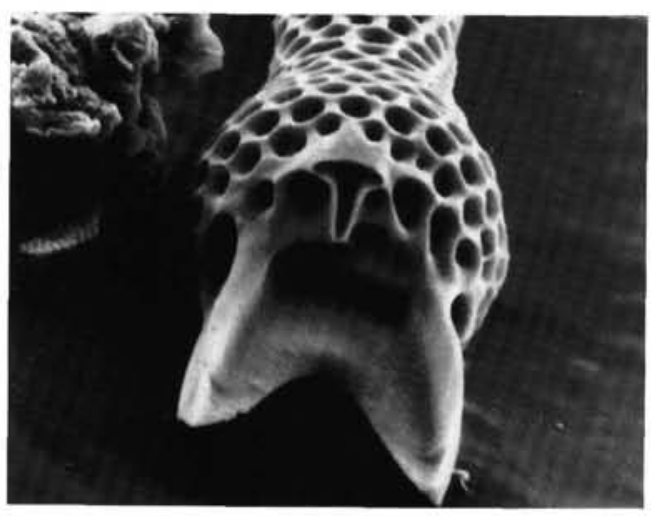

6

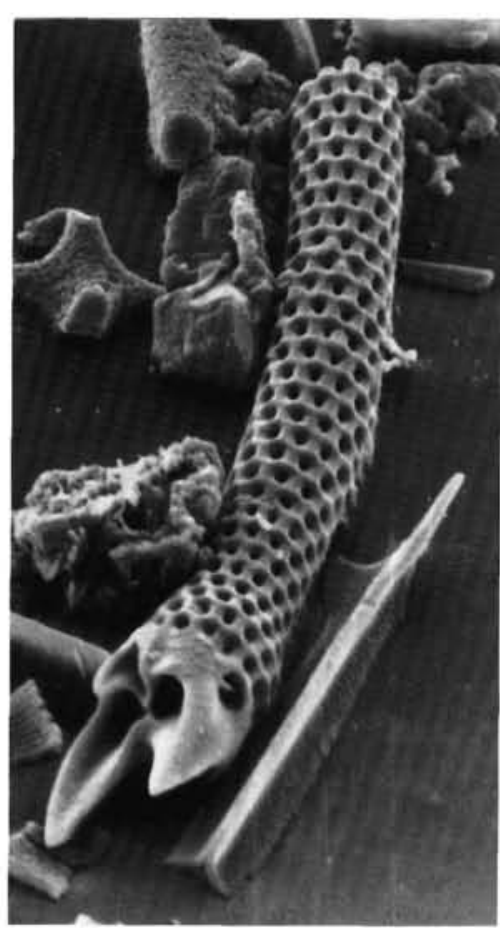

7

Plate 8. (Scale bar $=10 \mu \mathrm{m}) \quad$ 1, 2, 5, 6. Gladius antiquus Forti and Schulz, SEM, Sample 113-693B-19X-4, 77-78 cm $(2,6)$ external view of valve face with linking apparatus, note structure of three-buttressed spines and corresponding scrobisculi. 3, 4. Gladius antiquus var. tenuis var. nov, $\mathrm{SEM},(3,4)$ same specimen, note in (4) structure of apical linking spines and triangular scrobisculi located on marginal ridge, Section 113-693A44R, CC. 7. Gladius antiquus var. tenuis var. nov., SEM, valve with curved pervalvar axis, Sample 113-693B-19X-4, 103-104 cm. 

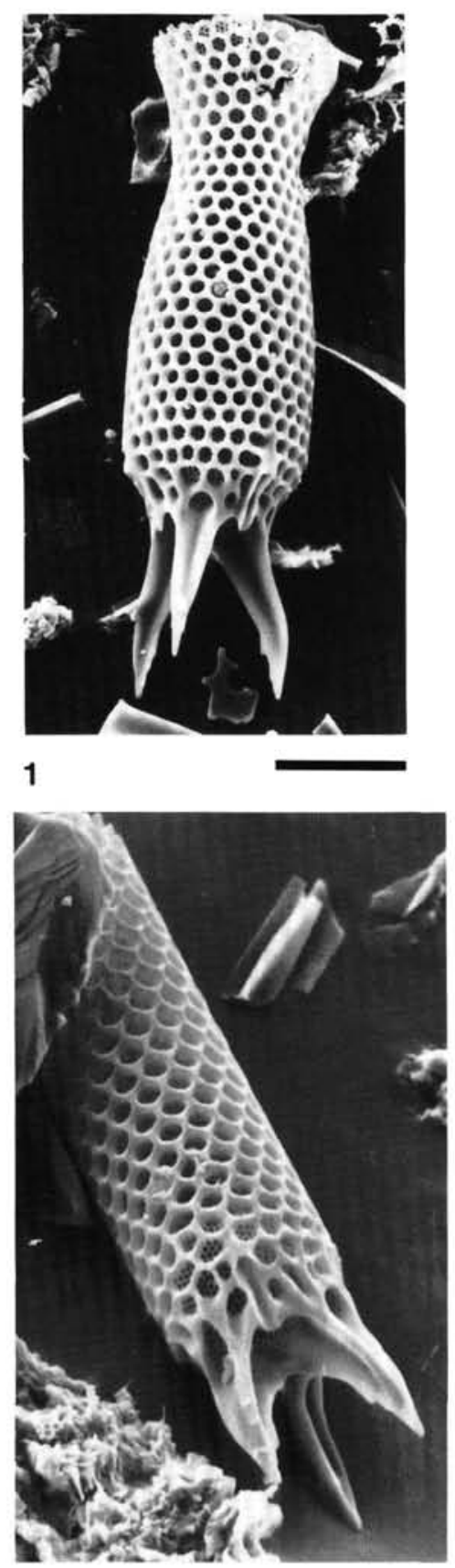

4

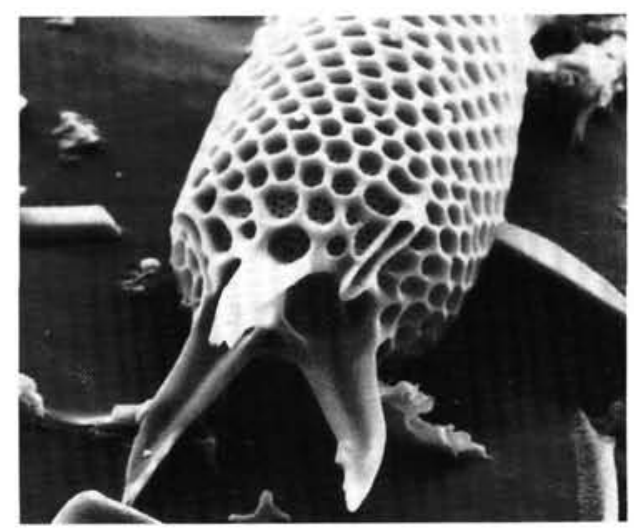

2

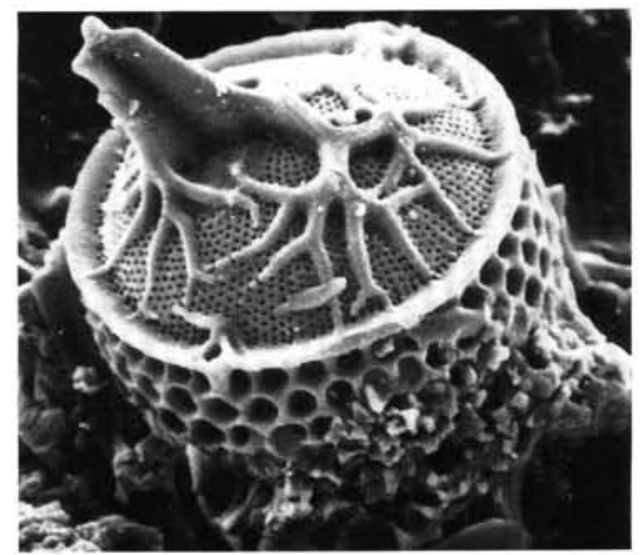

\section{5}

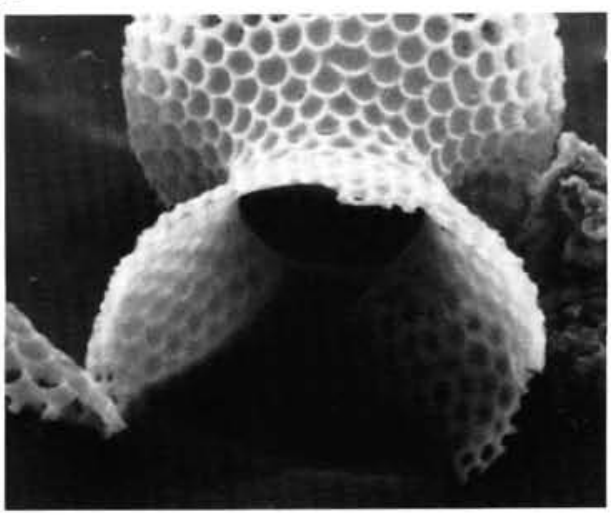

6

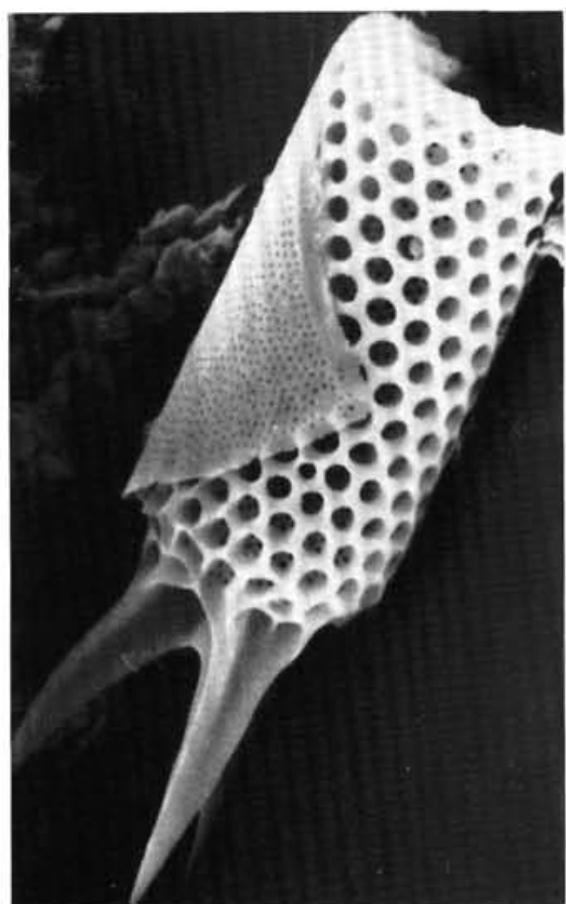

3

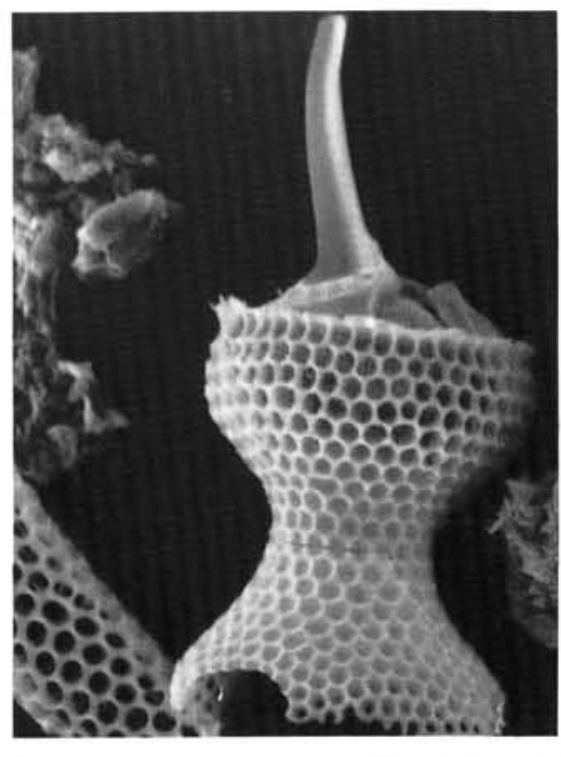

7

Plate 9. (All specimens from Sample 113-693B-19X-4, 77-78 cm, unless stated otherwise; scale bar $=10 \mu \mathrm{m}$ ) 1, 2. Gladius trispinosus sp. nov., SEM, same specimen, note structure of linking apparatus with three-buttressed spines, serrate ornamentation on inside of spine tips, and slit-like structure of scrobisculi. 3, 4. Gladius trispinosus var. tenuis var. nov., SEM, (3) note structure of girdle band. 5-7. Gladius rhizophorus sp. nov., SEM, (5) valve face, spines of linking apparatus broken, note multifurcated costae and shape of scrobisculi located on marginal ridge, Sample 113-693B-19X-4, 103-104 cm; $(6,7)$ same specimen, inside view of lower portion of valve mantle, note differentiated structure of basal siliceous layer and shape of linking spines, one spine broken. 

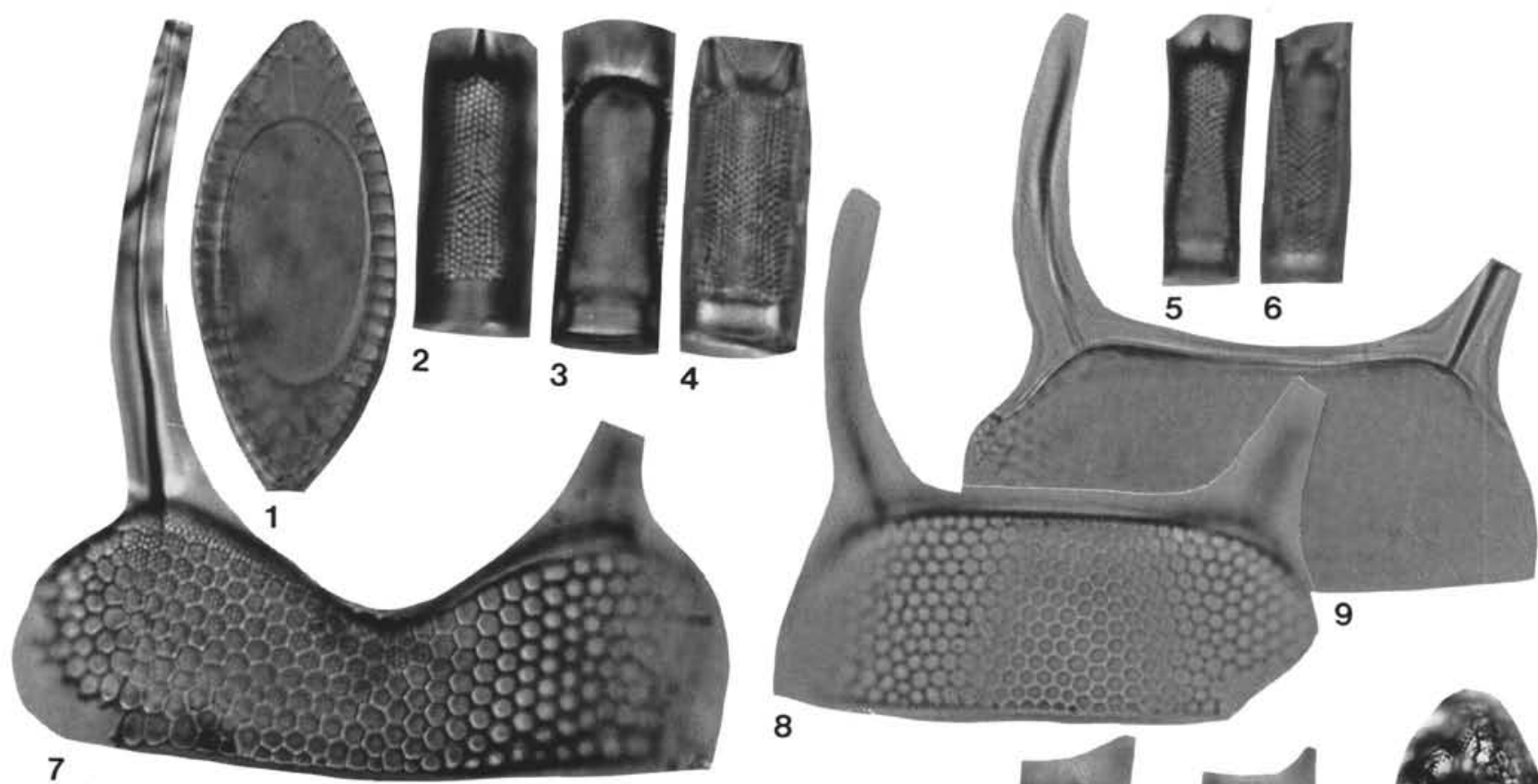

9

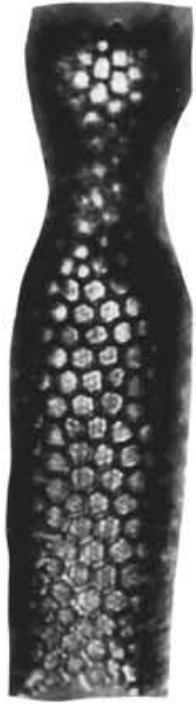

10

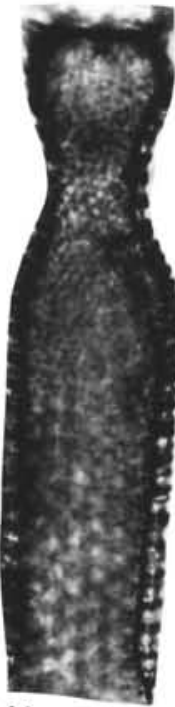

11

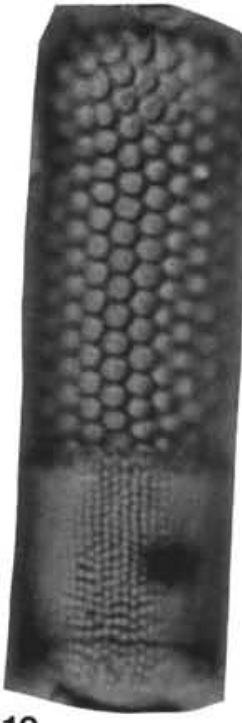

12

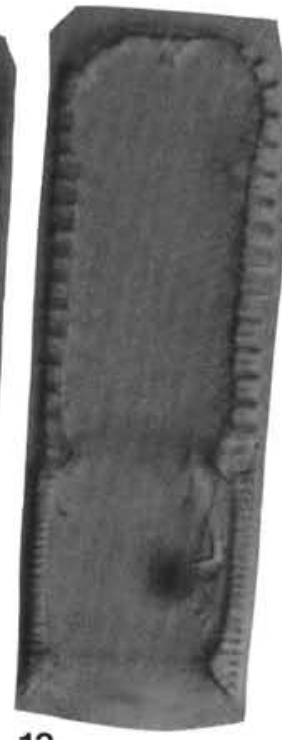

13

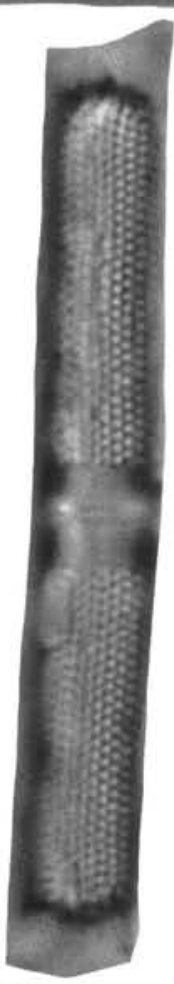

14
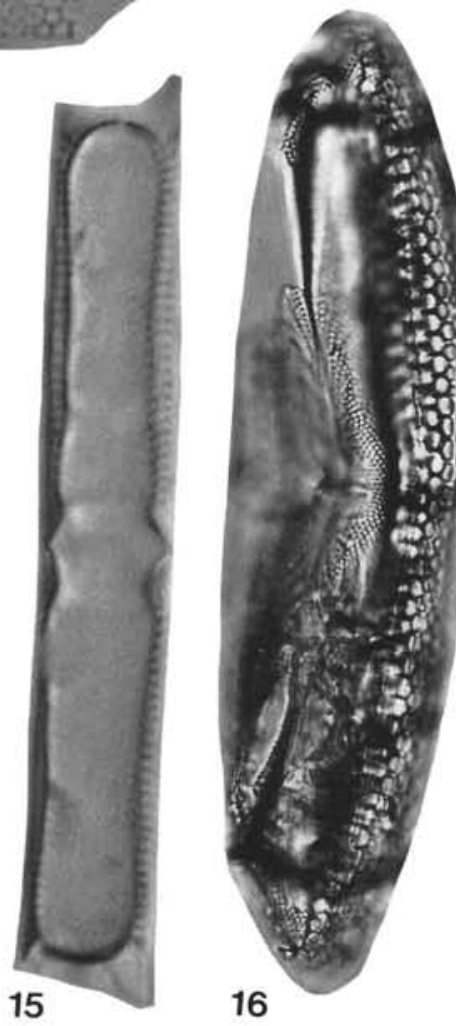

Plate 10. 1. Kerkis pseudoseptal plate, Sample 113-693B-19X-4, 103-104 cm, $\times 1000$. 2-6. Archepyrgus melosiroides sp. nov., (2-4) (5, 6) valve mantle view at different focus, note "Ringleiste", Sample 113-693B-19X-4, 103-104 cm, $\times 1500$. 7. Kerkis bispinosa sp. nov., holotype, valve manthe view, Sample 113-693B-19X-4, 103-104 cm, x 1000. 8, 9. Kerkis sp. valve mantle view at different focus, Sample 113-693B-19X-4, 103-104 cm. 10, 11. Gladiopsis lagenoides sp. nov., holotype, valve mantle view at different focus, note apical corona of spinulae, internal protrusion of apical sipho-shaped process, and attached girdle band, Sample 113-693B-19X-4, 77-78 cm, $\times 1500.12,13$. Gladiopsis modica sp. nov., holotype, valve mantle view at different focus, note apical corona of spinulae, internal protrusion of apical sipho-shaped process, and attached girdle band, Sample 113-693B-19X-4, 103-104 cm, $\times 1500$. 14, 15. Archepyrgus melosiroides sp. nov., holotype, girdle view of frustule at different focus, Sample 113693B-19X-4, 77-78 cm, $\times 2000$. 16. Kerkis bispinosa sp. nov., oblique view on external valve face, Sample 113-693B-19X-4, 77-78 cm, $\times 1500$. 


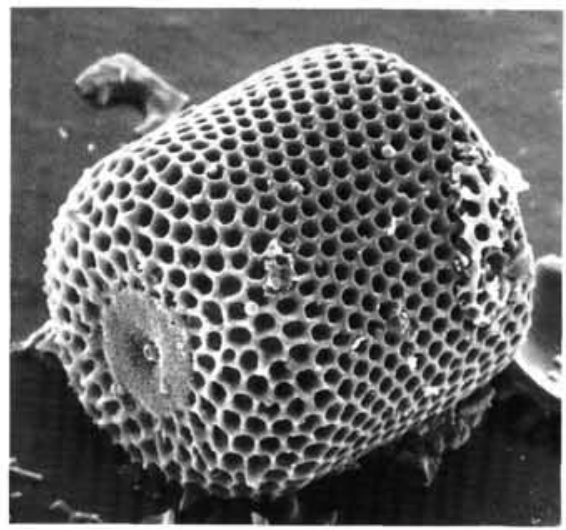

1

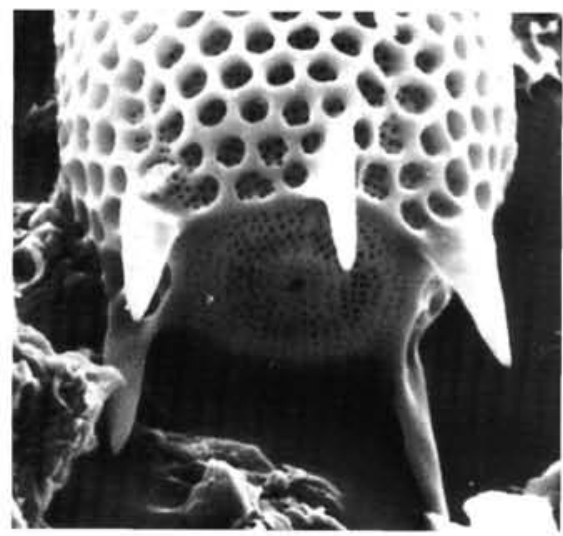

4

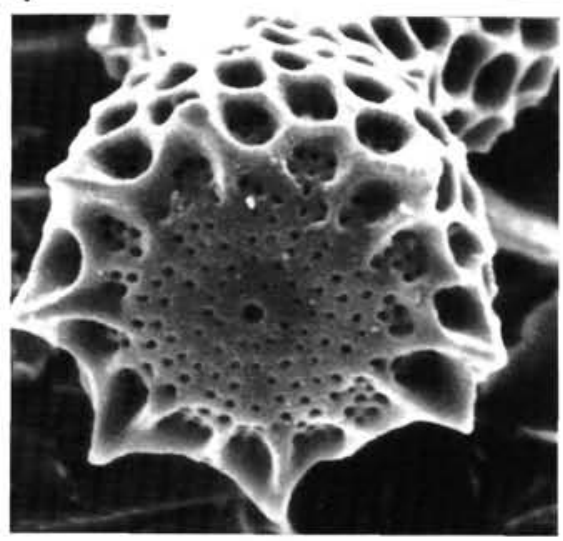

7

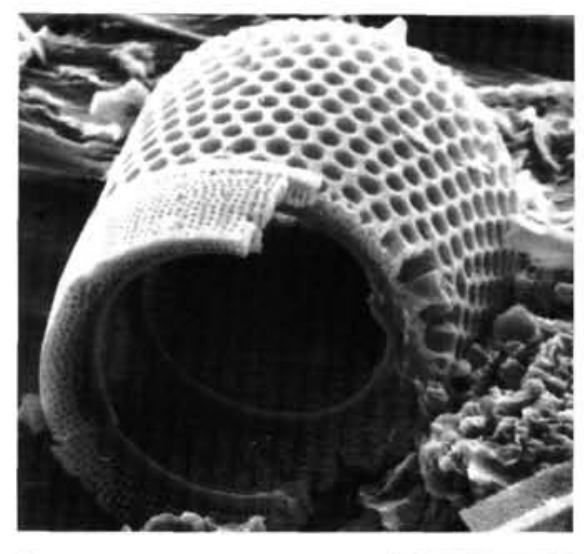

2

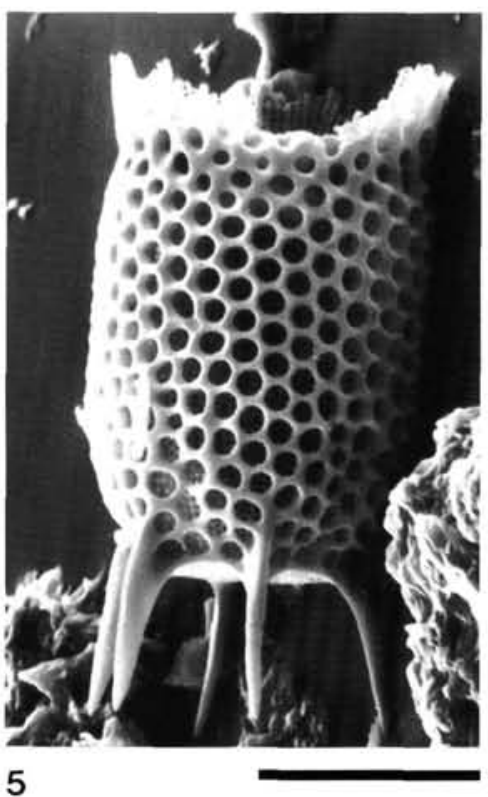

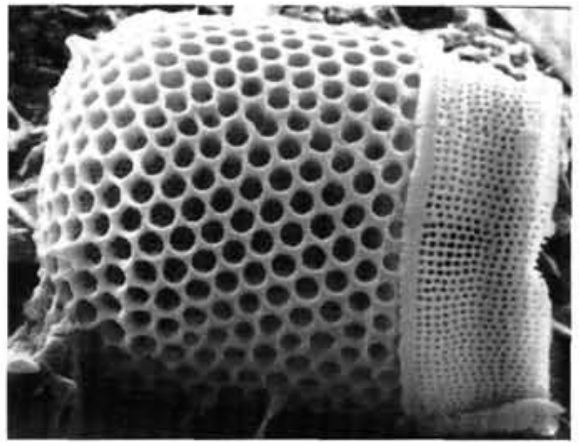

3

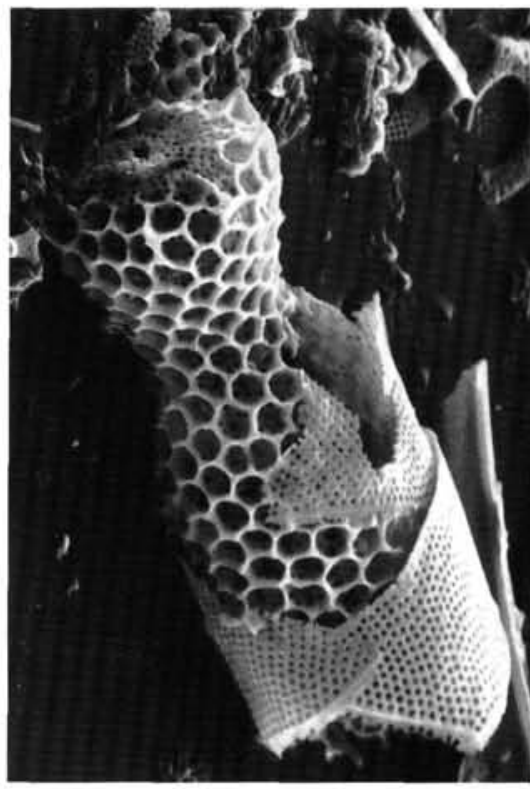

6

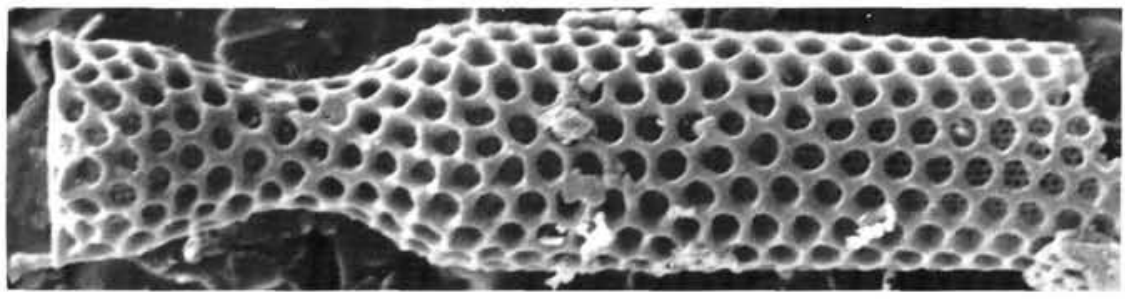

8

Plate 11. (All specimens from Sample 113-693B-19X-4, 77-78 cm, unless stated otherwise; scale bar $=10 \mu \mathrm{m}$ ) 1-3. Gladiopsis modica sp. nov., SEM, (1) external view of valve face with central sipho-shaped process and valve mantle, Section 113-693B-19X, CC.; (2), valve margin and attached girdle band; (3) valve mantle and girdle band, note apical corona of spinulae. 4, 5. Gladiopsis aff. modica, SEM, same specimen, note apical corona of spines and the absence of scrobisculi. 6-8. Gladiopsis lagenoides sp. nov., SEM, (6) external view of valve, apical sipho-shaped process, note structure of girdle band; $(7,8)$ same specimen, valve face with outer opening of central sipho-shaped process, note apical corona of spinulae and valve mantle, and wall ornamentation by pseudoloculi, Sample 113-693B-19X-4, 103-104 cm. 

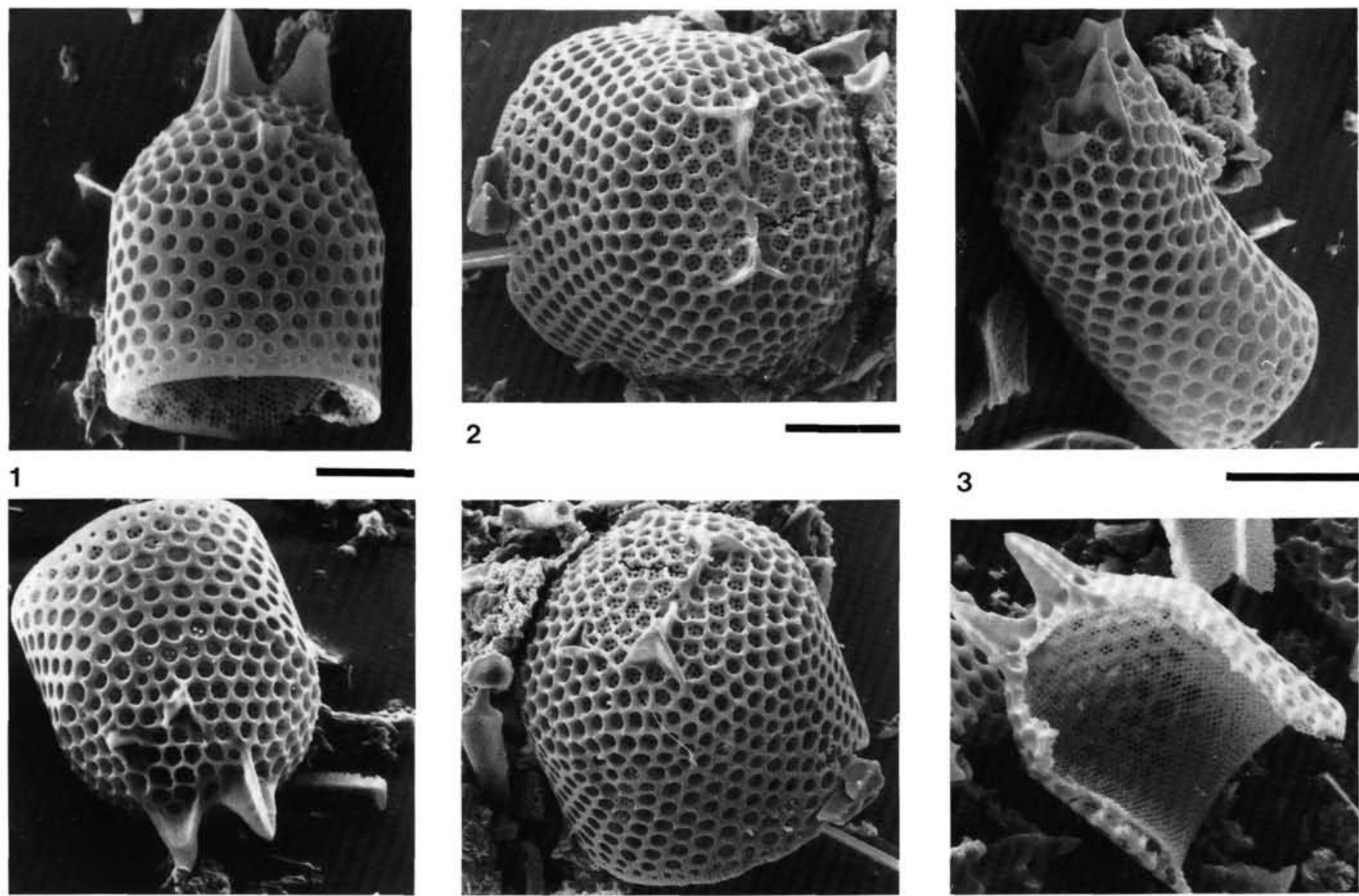

4

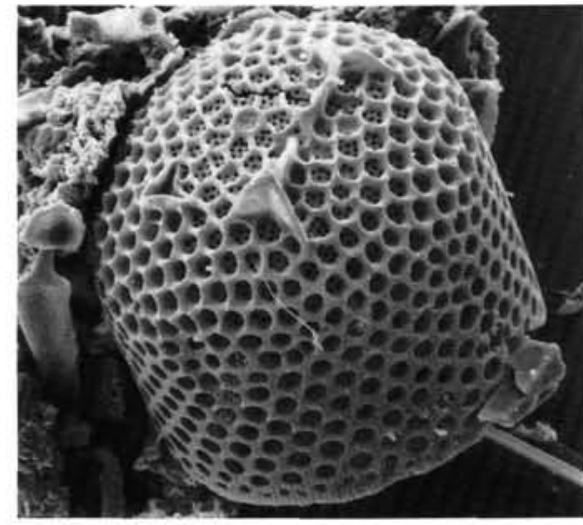

3

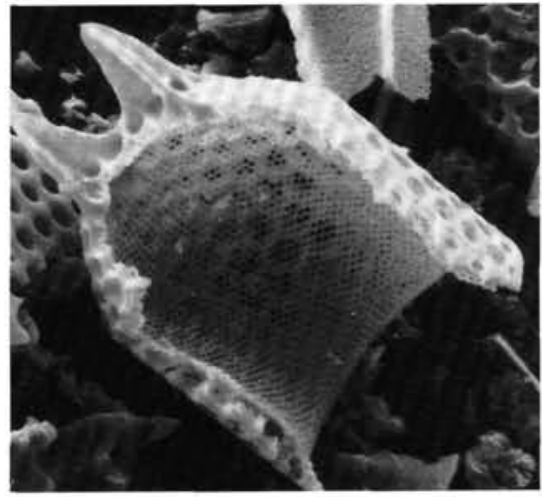

5

6

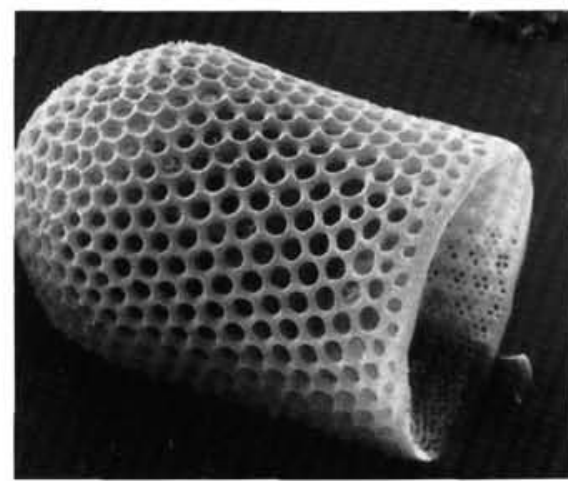

8

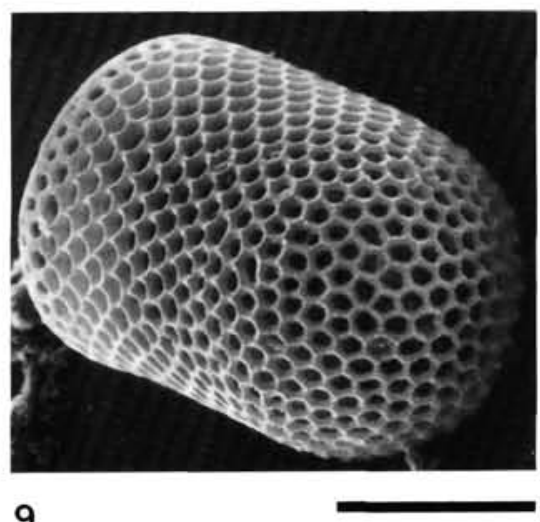

9

Plate 12. (All specimens from Sample 113-693B-19X-4, 77-78 cm; scale bar $=10 \mu \mathrm{m}$ ) 1-7. Amblypyrgus campanellus sp. nov., SEM, (1-5, 7) external view of valve face with linking apparatus and valve mantle; (6) internal view of valve mantle structure. 8, 9. Amblypyrgus campanellus sp. nov., valves without linking structure interpreted to represent end-members of chains. 


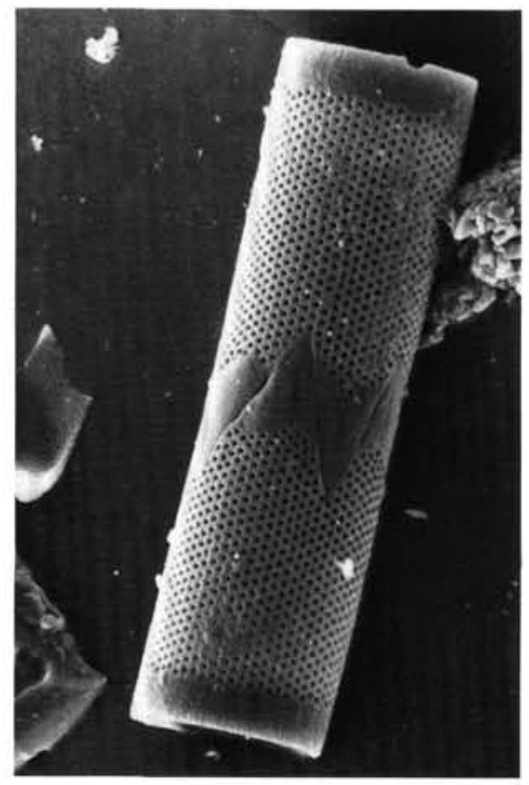

1

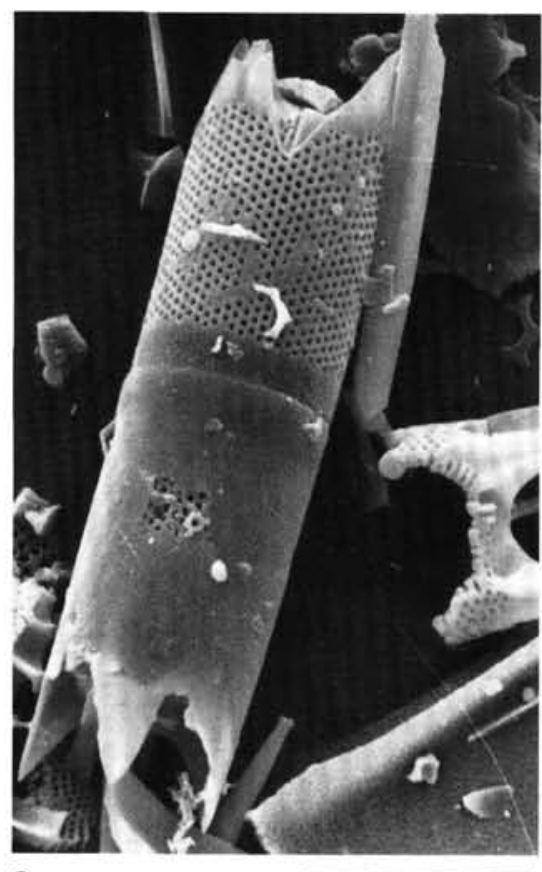

6

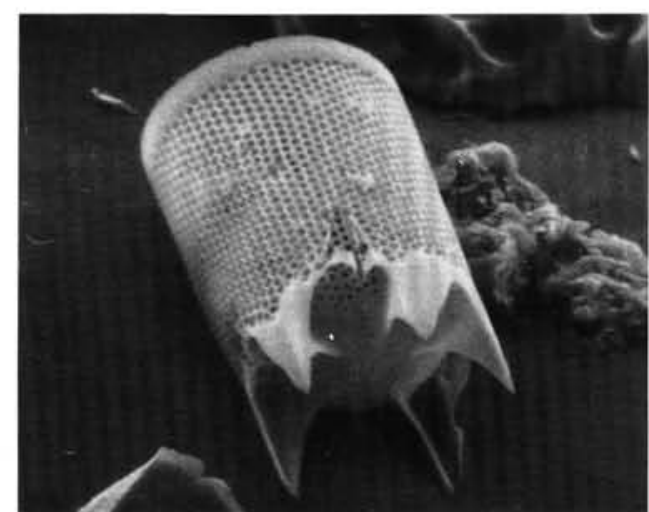

2

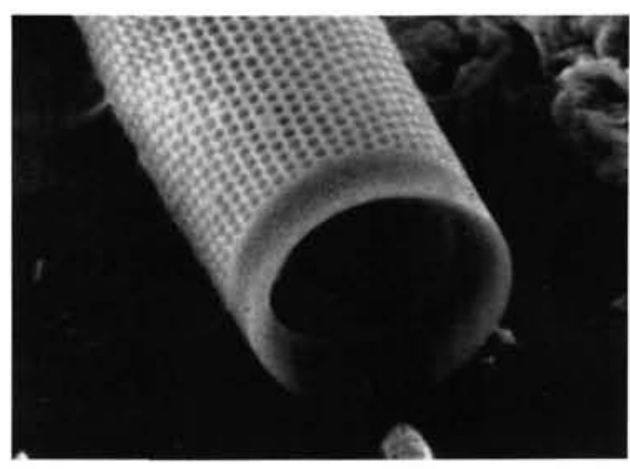

4

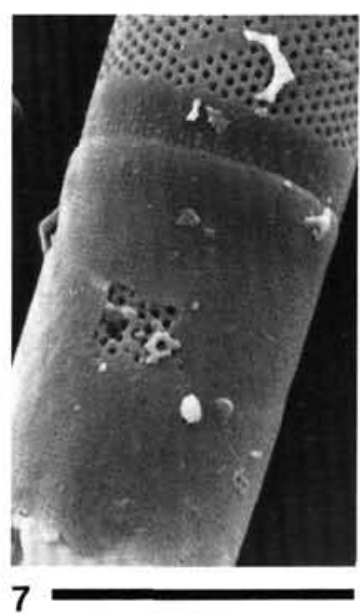

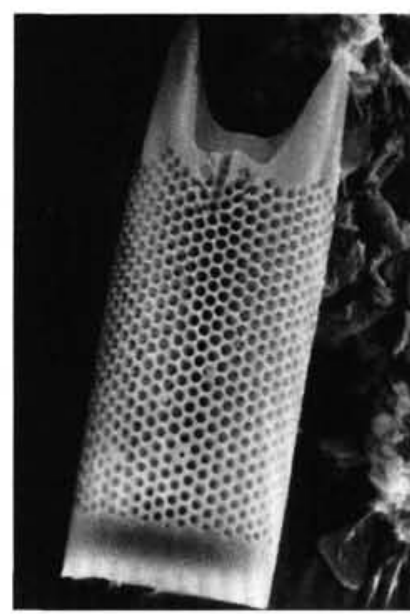

3

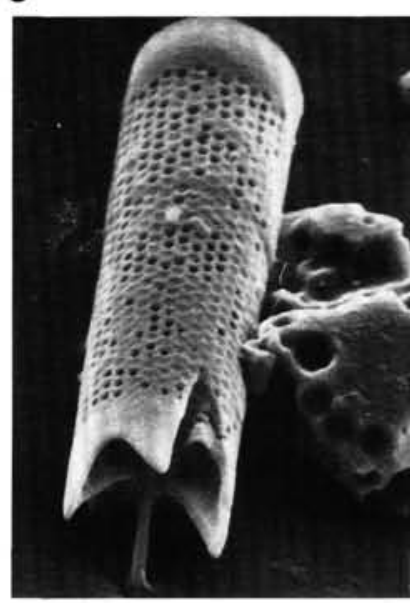

5

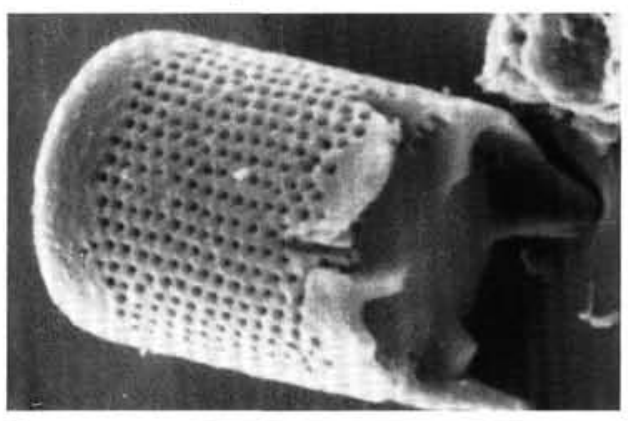

8

Plate 13. (All specimens from Sample 113-693B-19X-4, 77-78 cm, unless stated otherwise; scale bar $=10 \mu \mathrm{m}$ ) 1-8. Archepyrgus melosiroides sp. nov., SEM (1) part of chain, note interdigitating linking spines; (2) valve face with linking apparatus, note structure of valve face, three-buttressed linking spines and shape of scrobiculus; $(3,5)$ valve margin; $(4)$ mantle edge with "Ringleiste"; $(6,7)$ frustule, girdle band covering the hypovalve, valve face, Section 113-693A-44R, CC; (8) Sample 113-693B-19X-4, 103-104 cm. 


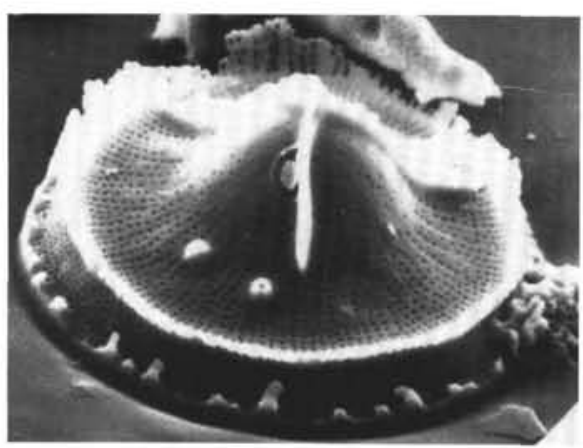

1

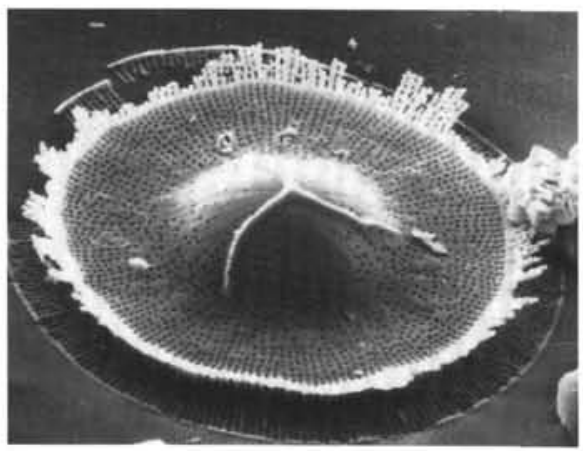

4

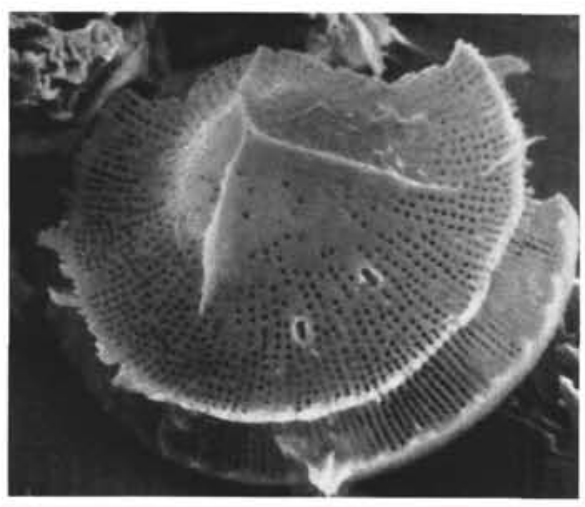

7

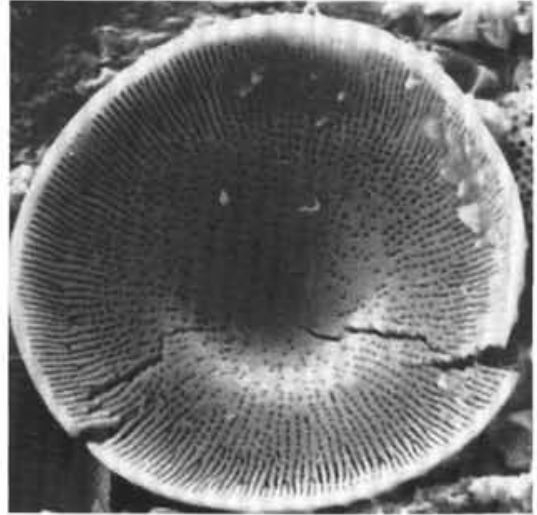

$=3$

2

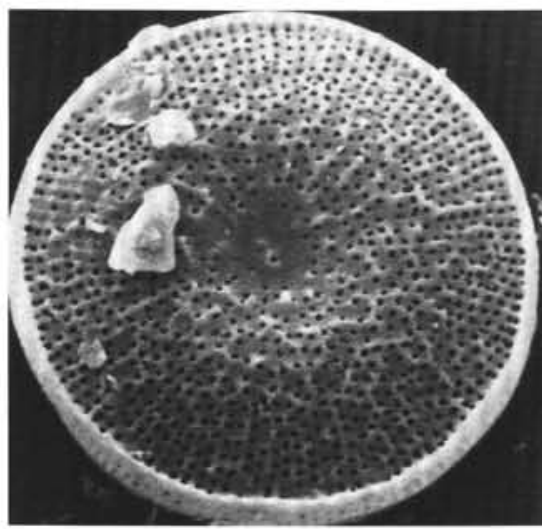

5

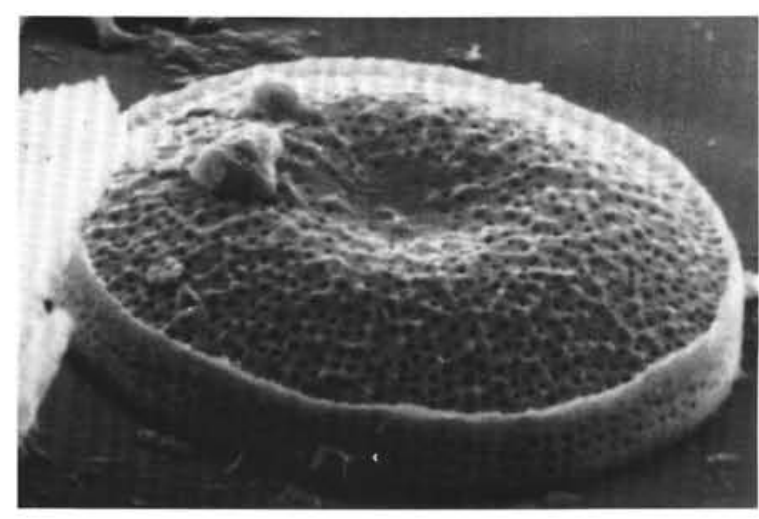

8

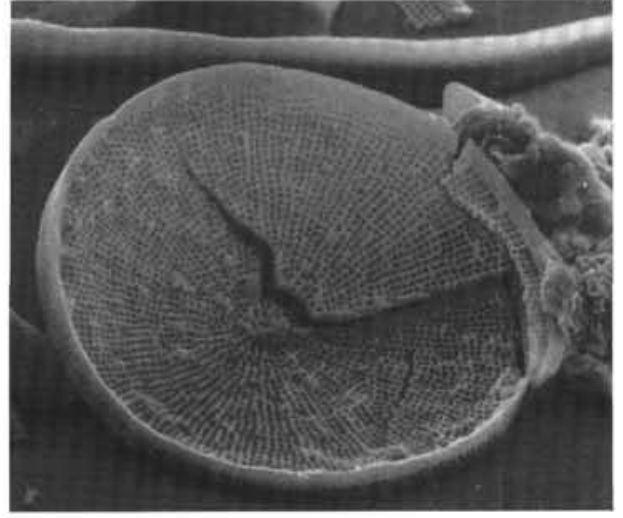

3

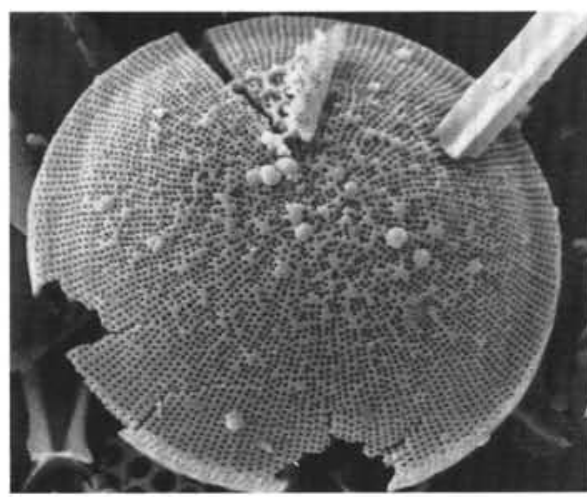

6

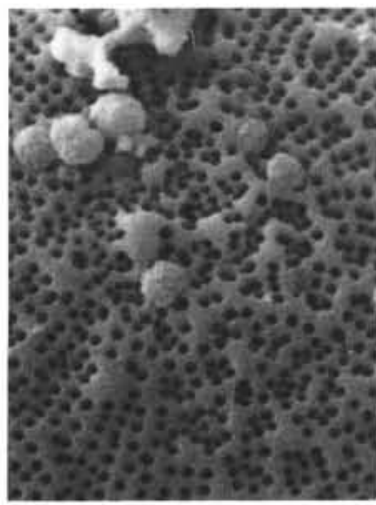

9

Plate 14. (All specimens from Sample 113-693B-19X-4, 77-78 cm, unless stated otherwise; scale bar $=10 \mu \mathrm{m}$ ) 1, 2, 4, and 7. Trochus elegantulus sp. nov., SEM, $(1,4,7)$ of external valve face with marginal ridge and scissurate-haplo processes; (2) internal view of valve face. 3, 6, 9. Microorbis convexus sp. nov., SEM, (3) internal valve face with distinct central area perforated by punctate-haplo processes; (6), external valve face without differentiated central area, Section 113-693A-44R, CC; (9) detail of (6). 5, 8. Microorbis undulatus sp. nov., SEM, (5) external valve face; (8) oblique view showing valve mantle and marginal ridge. 

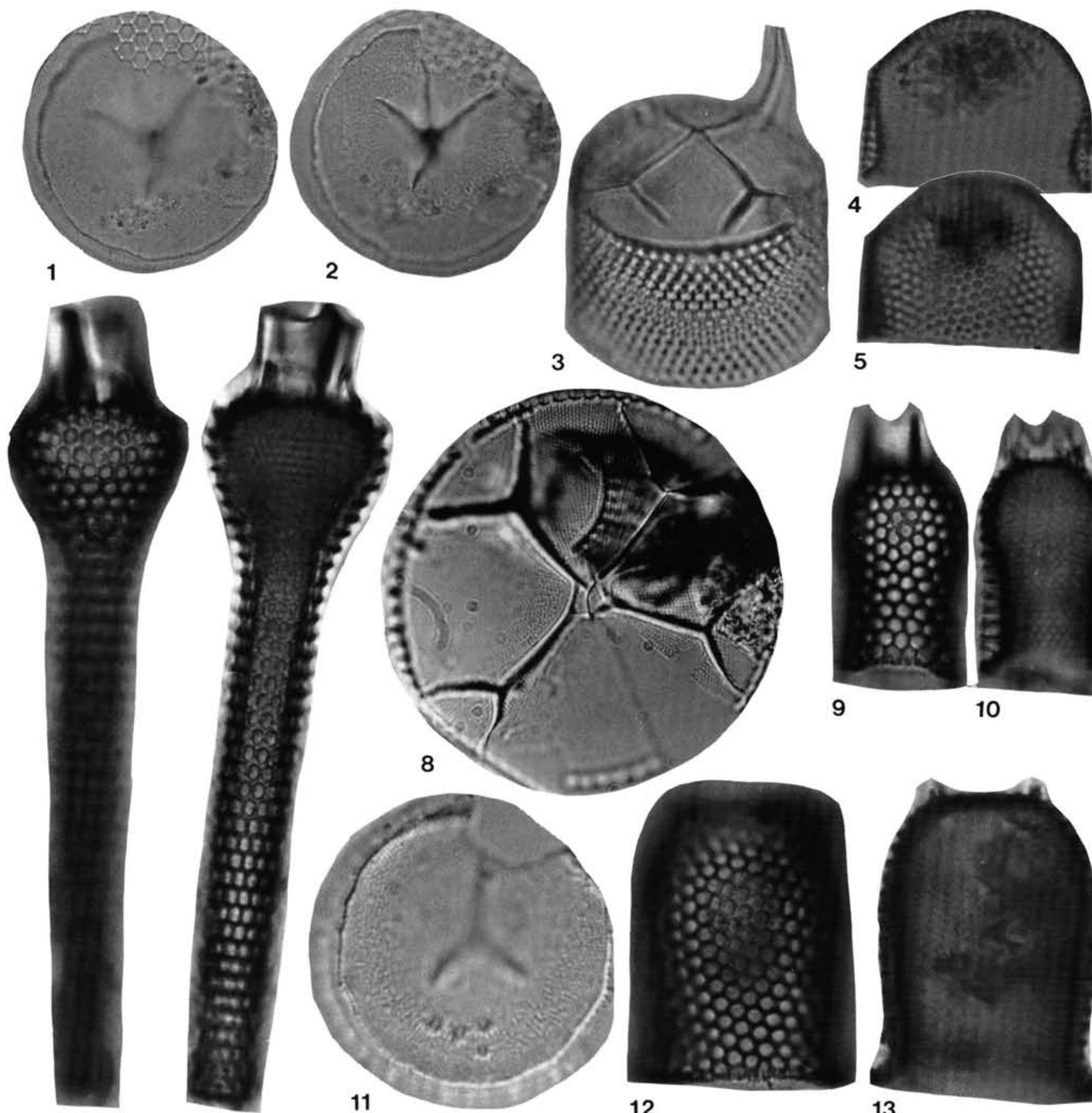

5
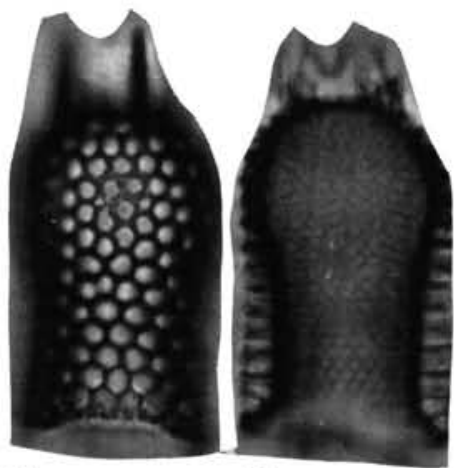

9

10

6

7

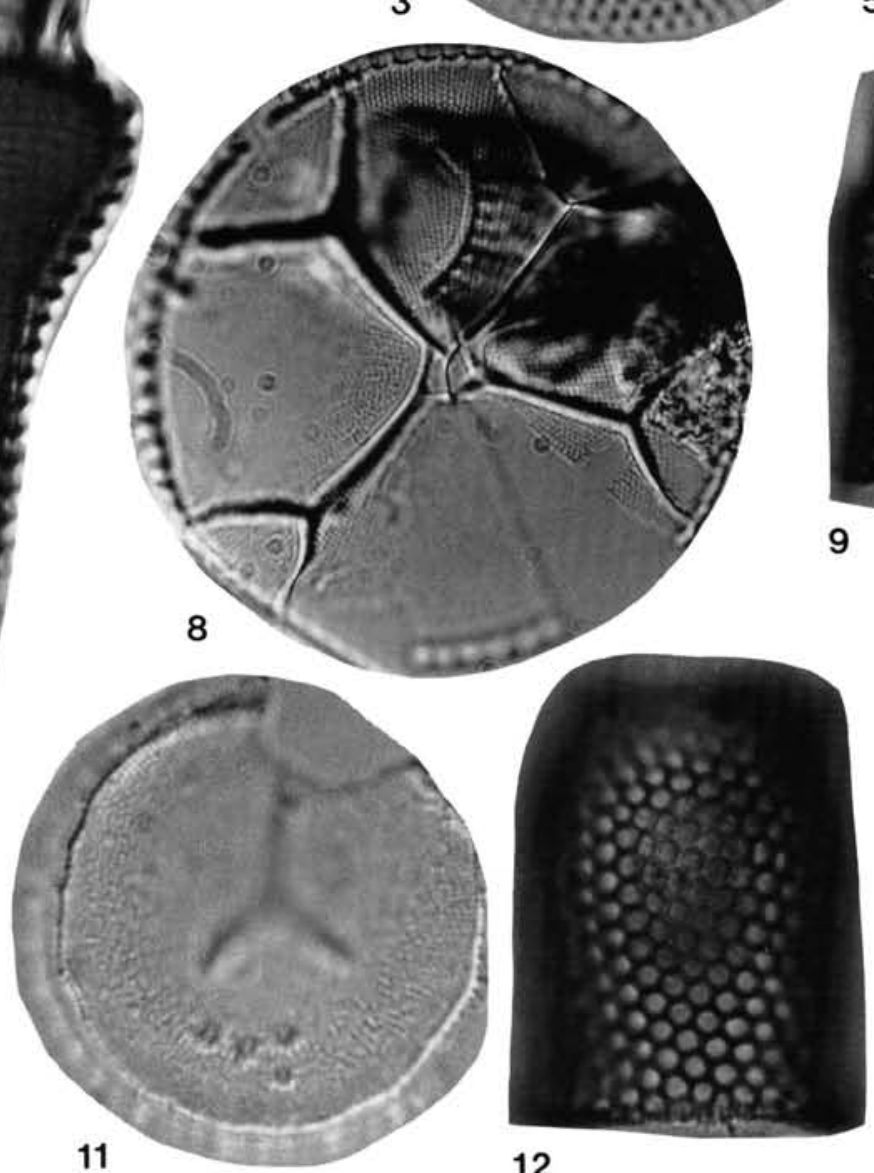

12

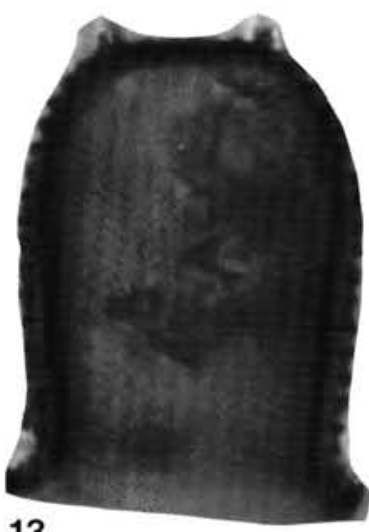

Plate 15. (All specimens from Sample 113-693B-19X-4, 103-104 cm, unless stated otherwise) 1, 2, 11. Trochus elegantulus sp. nov., (1, 2) holotype, valve face at different focus, $\times 1000$; (11) Sample 113-693B-19X-4, 77-78 cm, $\times 1500.3,8$. Gladius perfectus sp. nov., (3) holotype, oblique view on valve face and mantle, $\times 750 ;(8)$ valve face, $\times 1000.4,5,9,10,12,13$. Amblypyrgus campanellus sp. nov., $(4,5)$ paratype, valve mantle view at different focus, $\times 1000 ;(9,10)$ valve mantle view at different focus, $\times 1500 ;(12,13)$ valve mantle view at different focus, Sample 113-693B$19 \mathrm{X}-4,77-78 \mathrm{~cm}, \times 1500$. 6, 7. Gladius antiquus Forti and Schulz, valve mantle view at different focus, Sample 113-693B-19X-4, 77-78 cm, $\times 1500$. 


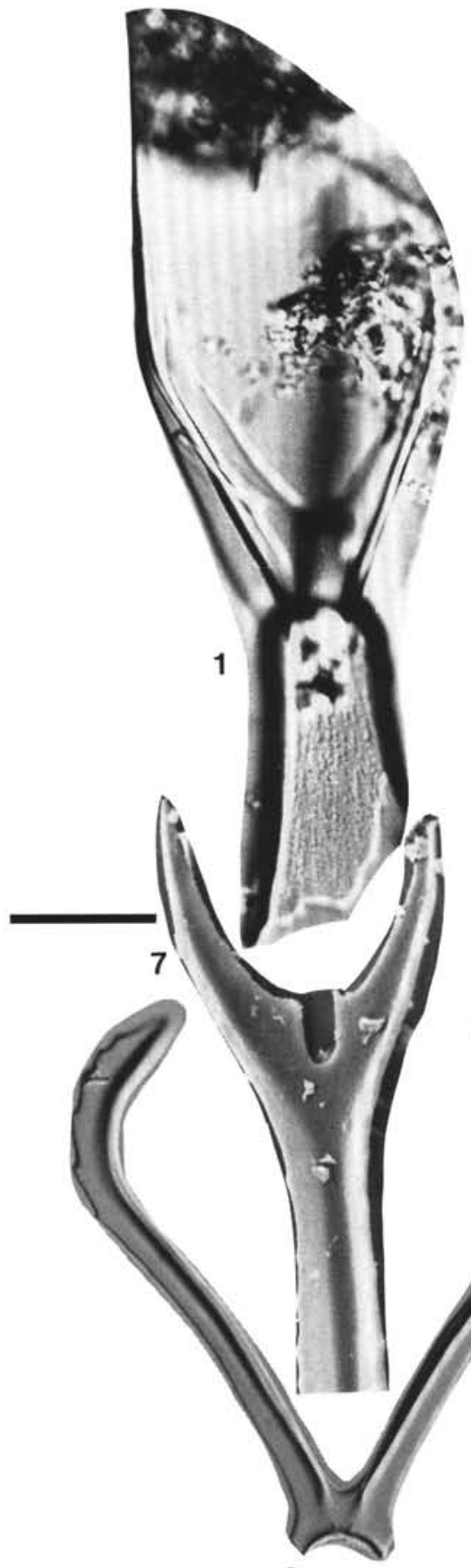

6

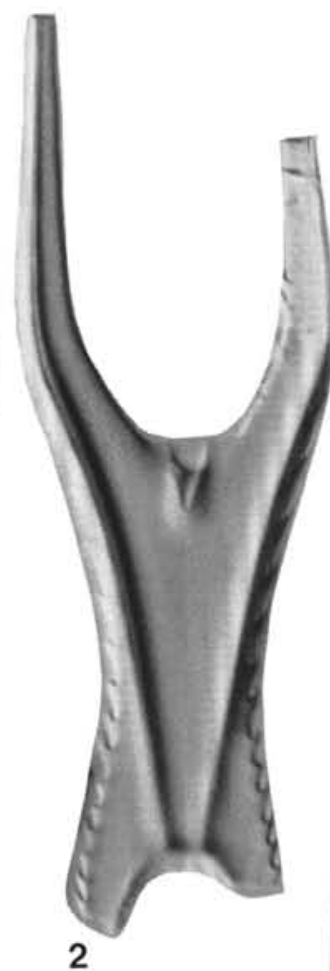

2

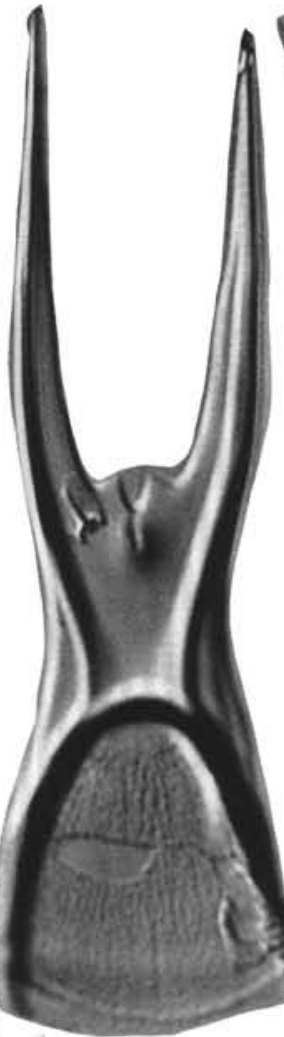

3

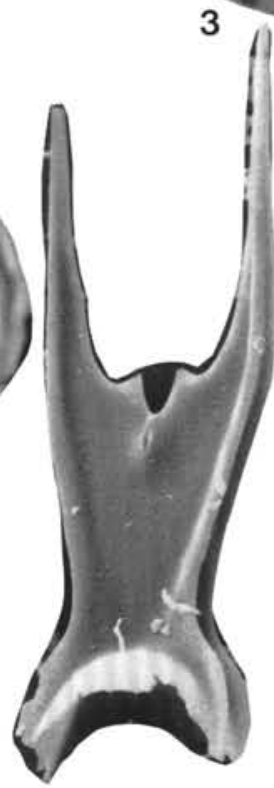

8

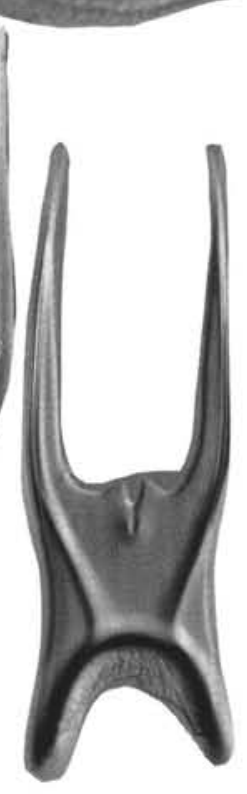

9

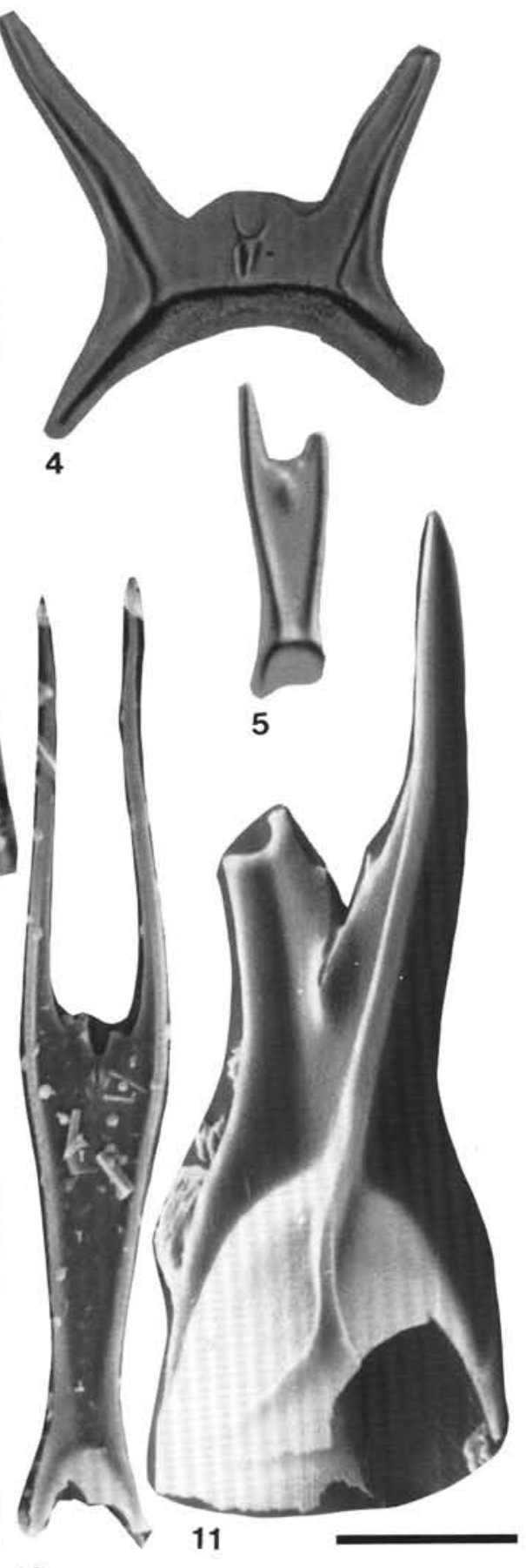

$10=$

Plate 16. 1. Kreagra tripartita sp. nov., holotype, Sample 113-693B-19X-4, 77-78 cm, $\times 500$. 2. Kreagra forfex f. serrata $\mathrm{n}$. f., holotype, Sample 113-693B-19X-4, 103-104 cm, $\times 750$. 3-5, 8-11. Kreagra forfex sp. nov., (3) holotype, Sample 113-693B-19X-4, 77-78 cm, $\times 750 ;(4)$ Sample 113-693B-19X-4, 77-78 cm, ×750; (5) Sample 113-693B-19X-4, 77-78 cm, $\times 1000$; (8) SEM, Section 113-693A-44R, CC, bar = 10 $\mu \mathrm{m}$; (9) Sample 113-693B-19X-4, 77-78 cm, $\times 500$; (10) Section 113-693A-44R, CC, bar $=10 \mu \mathrm{m}$; (11) SEM, Section 113-693A-44R, CC, bar $=10 \mu \mathrm{m}$. 6. Kreagra bifalcata sp. nov., holotype, Sample 113-693B-19X-4, 77-78 cm, $\times 500$. 7. Kreagra sp. A, SEM, Section $113-693 \mathrm{~A}-44 \mathrm{R}, \mathrm{CC}$, bar $=10 \mu \mathrm{m}$. 

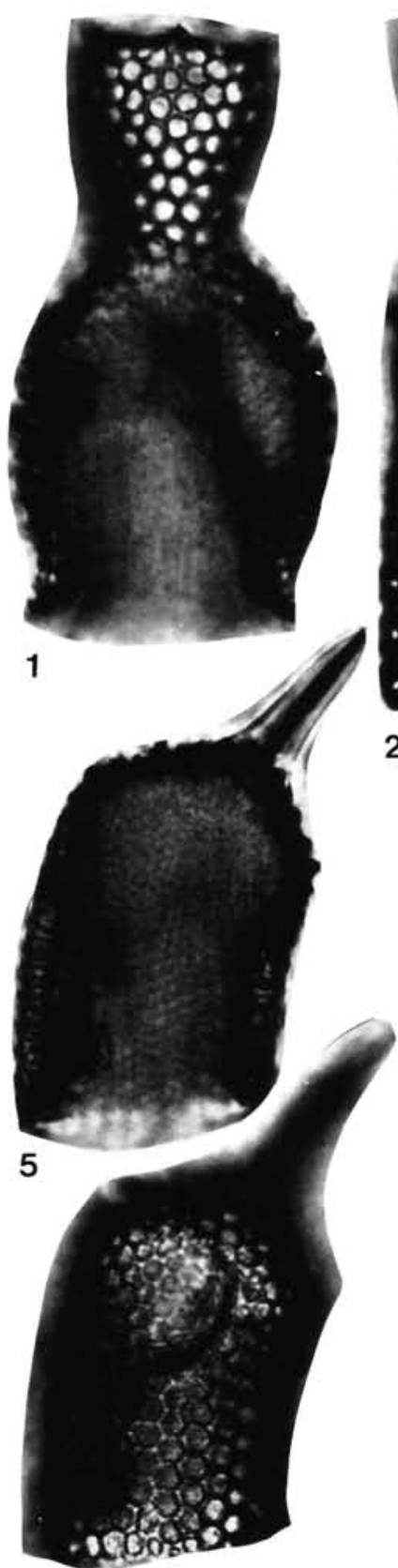

6

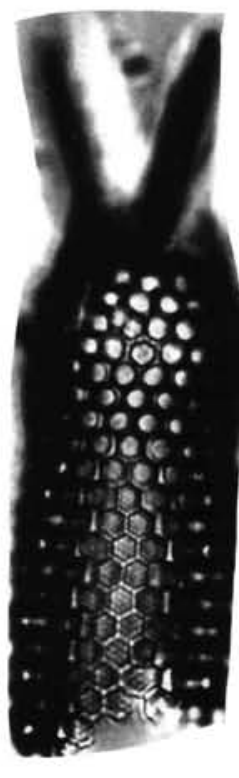

2

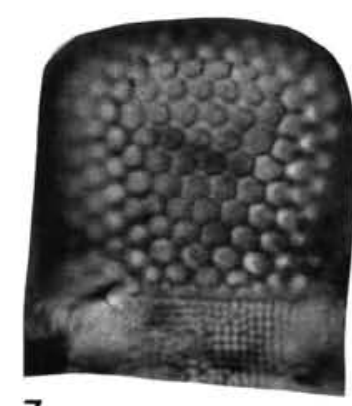

7

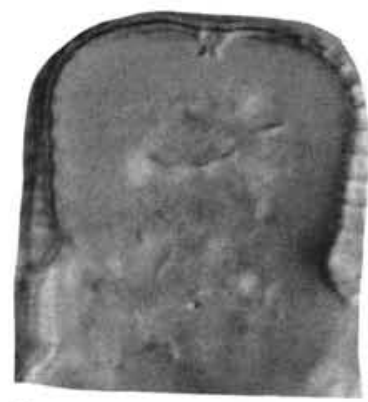

8

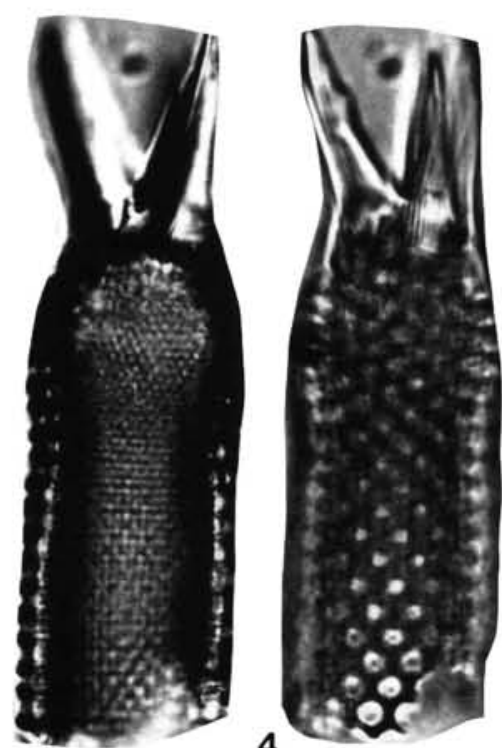

4

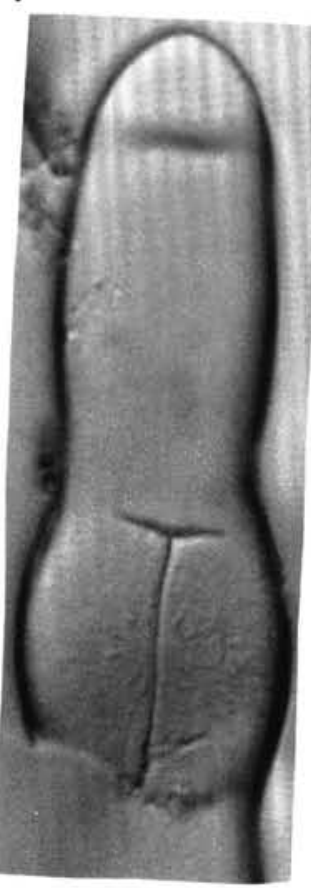

9

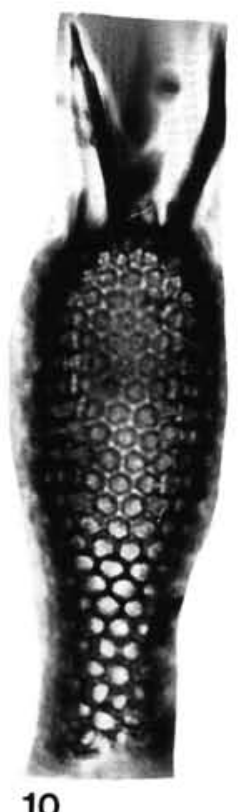

10

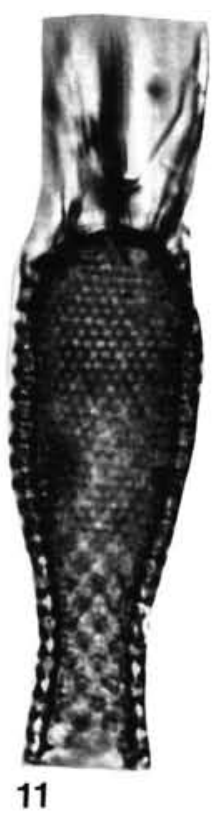

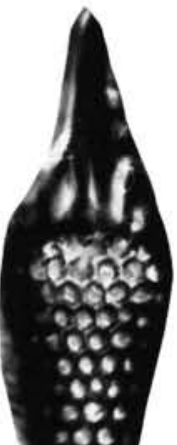

$x \rightarrow$

36.

30 1

4 ,

36

86

as
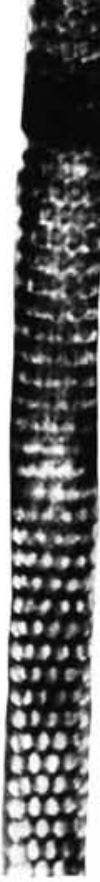

12

Plate 17. (All specimens from Sample 113-693B-19X-4, 77-78 cm; $\times 1500$ unless stated otherwise) 1. Rhynchopyxis siphonoides sp. nov., valve mantle view. 2-4. Gladius trispinosus var. tenuis var. nov., valve mantle view at different focus. 5, 6. Ancylopyrgus reticulatus sp. nov., holotype, valve mantle view at different focus. 7, 8. Gladiopsis modica sp. nov., valve mantle view at different focus, note internal protrusion of central apical sipho-shaped process, $\times 1000$. 9. Bilingua rossii sp. nov., valve face, note central ring of radial scissurate-haplo processes and central costa, $\times 2000$. 10, 11. Gladius trispinosus sp. nov, valve mantle view at different focus. 12. Gladius antiquus Forti and Schulz, valve mantle view. 


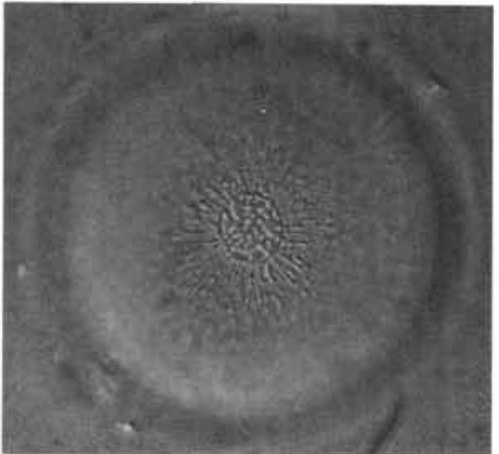

1

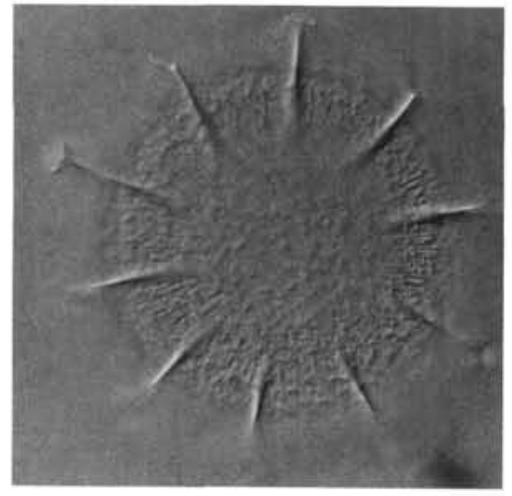

3

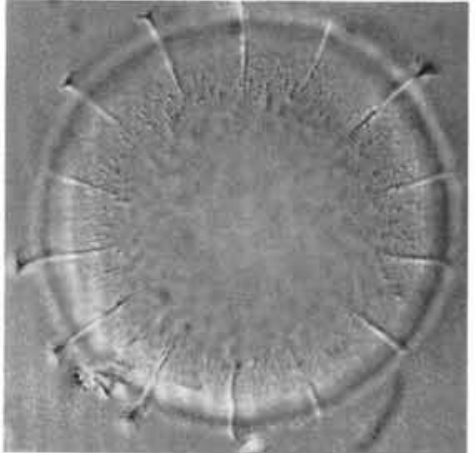

2

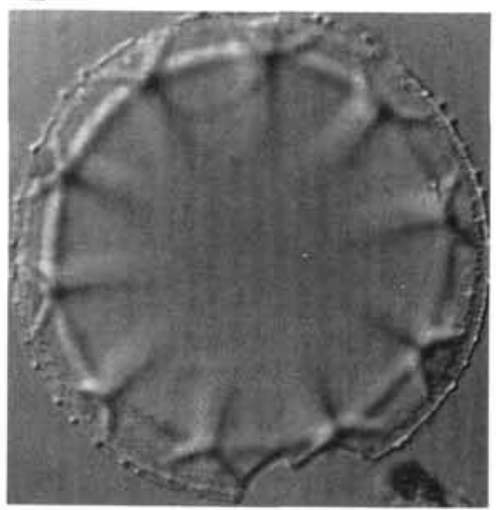

4

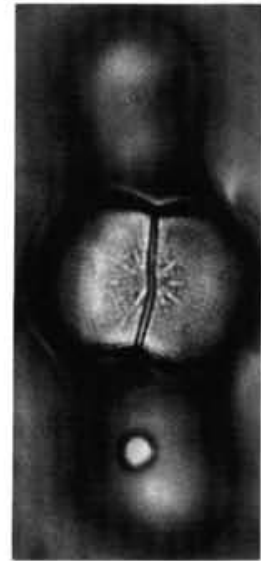

5

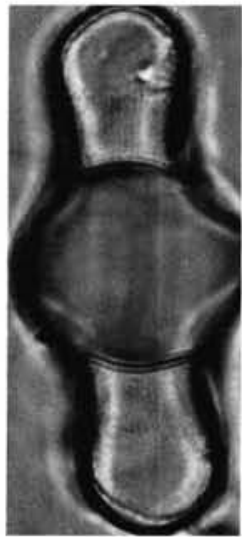

6

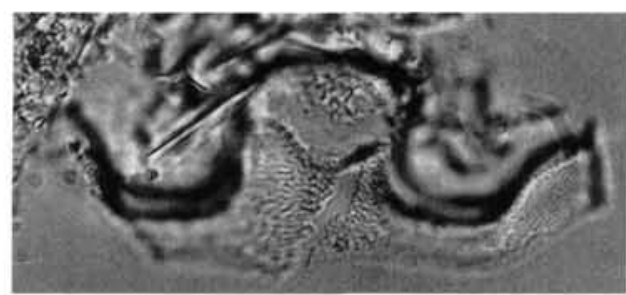

7
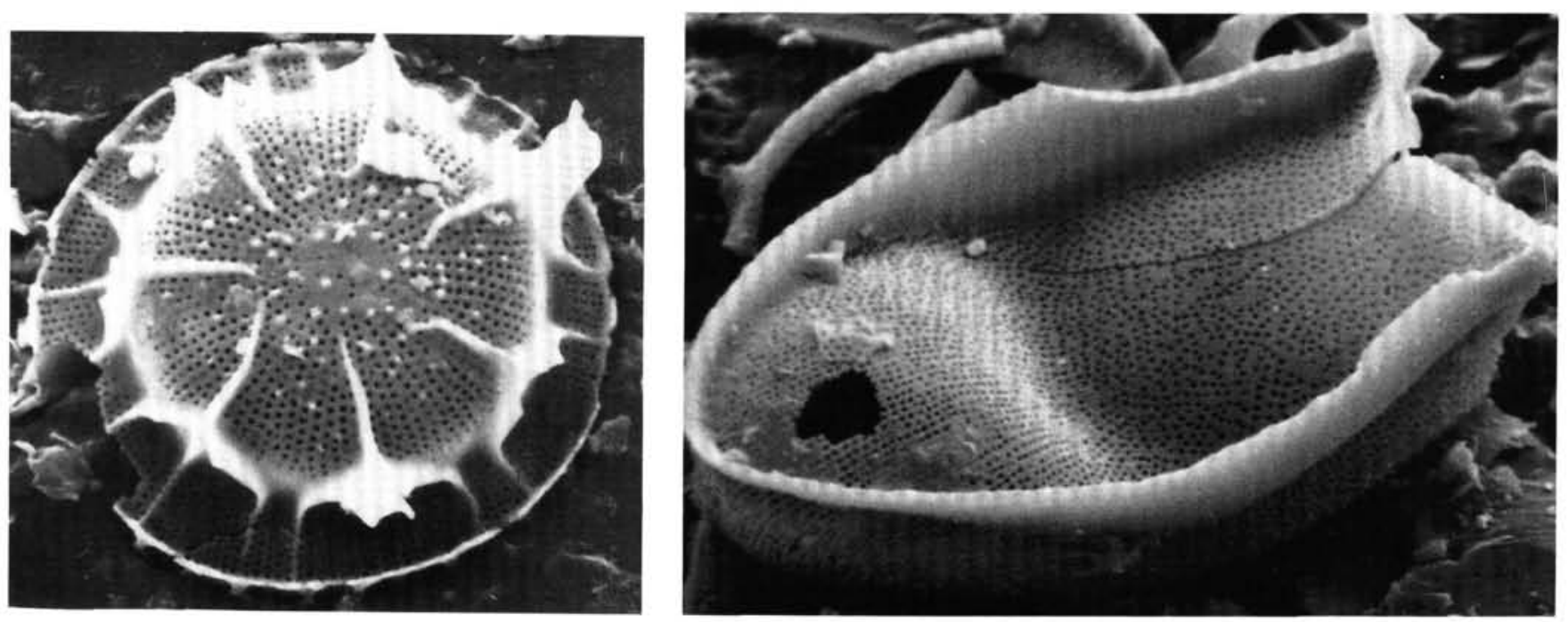

9

8

Plate 18. (All specimens from Sample 113-693B-19X-4, 77-78 cm, unless stated otherwise.) 1, 2. ?Microorbis convexus valve face at different focus, note distinct central area perforated by clustered punctate-haplo processes and marginal costae, Sample $113-693 \mathrm{~B}-19 \mathrm{X}-4,103-104 \mathrm{~cm}, \times 1000$. 3, 4, 8. ?Microorbis convexus, Sample 113-693B-19X-4, $77-78 \mathrm{~cm},(3,4)$ valve face at different focus, note marginal costae and central part of valve face not bearing punctate-haplo processes, $\times 1000$; (8) SEM of valve face, note structure of radial costae, bar $=10 \mu \mathrm{m}$. 5-7, 9. Bilingua rossii sp. nov., $(5,6)$ holotype, at different focus of valve face, note central ring of radial scissurate-haplo processes and central costa, $\times 1500$; $(7)$ girdle view, Sample 113-693B-19X-4, 103-104 cm, $\times 1000$; (9) SEM oblique view on outside of valve fragment with polar elevation, note marginal ridge and ornamentation of valve wall, bar $=10 \mu \mathrm{m}$. 

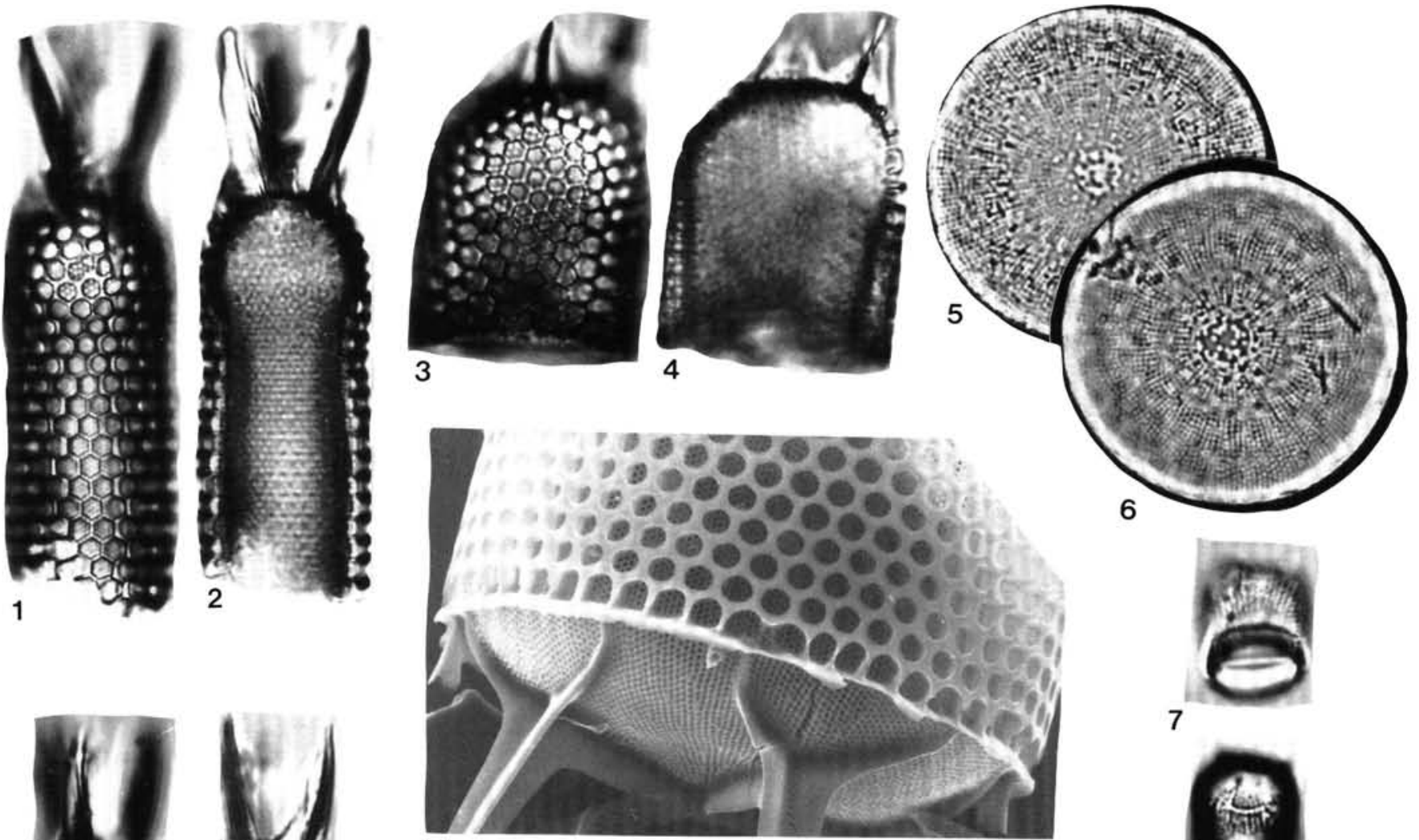

6
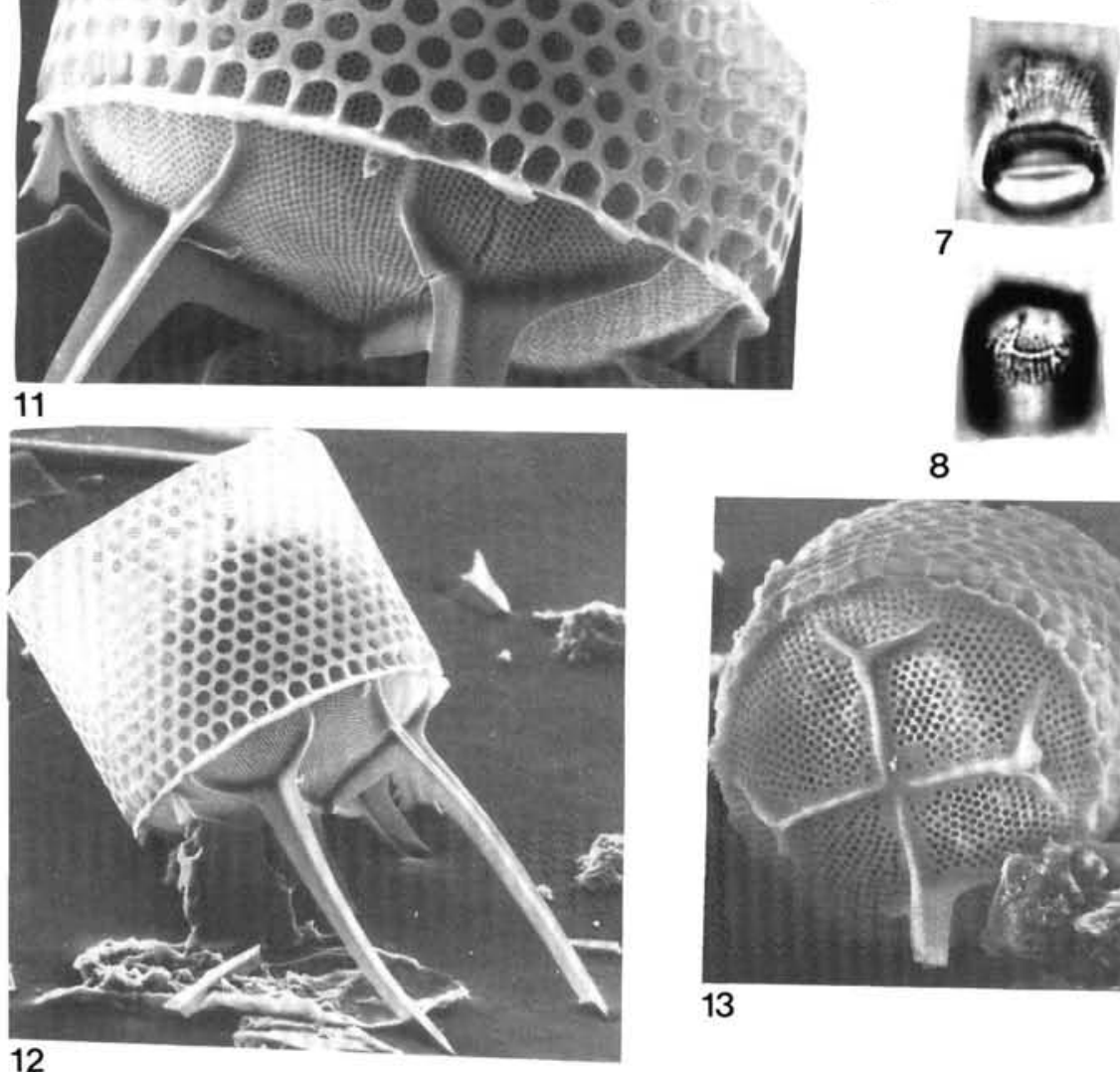

8

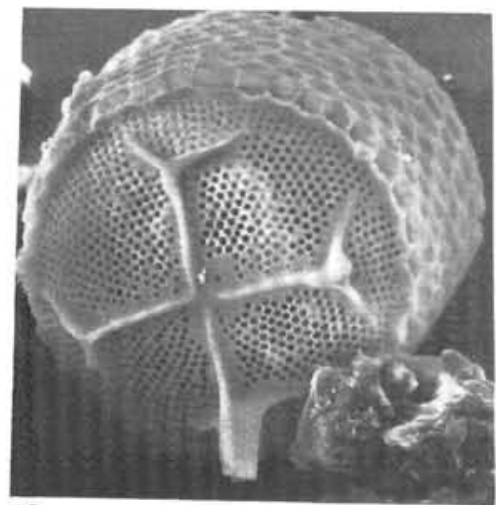

13

Plate 19. (All specimens from Sample 113-693B-19X-4, 77-78 cm; LM micrographs $\times 1500$, SEM-micrograph scale bars $=10 \mu \mathrm{m}$ ). $1,2$. Gladius trispinosus var. tenuis var. nov., holotype, valve mantle view at different focus. 3, 4. Amblypyrgus campanellus sp. nov., holotype, valve mantle view at different focus. 5, 6. Microorbis convexus sp. nov., paratype, valve face at different focus. 7, 8. Basilicostephanus mirabilis sp. nov., holotype, oblique view at different focus. 9, 10. Gladius trispinosus sp. nov., holotype, valve mantle view at different focus. 11-13. Gladius perfectus sp. nov., (11) SEM detail view of marginal ridge area of individual presented in (12), "tulip flower" scrobisculi shown near left and right edge of micrograph, scrobisculus located in center broken off at its point of attachment; (12) SEM view of valve mantle and linking spines; (13) SEM view of valve face, linking spines and scrobisculi broken off. 